
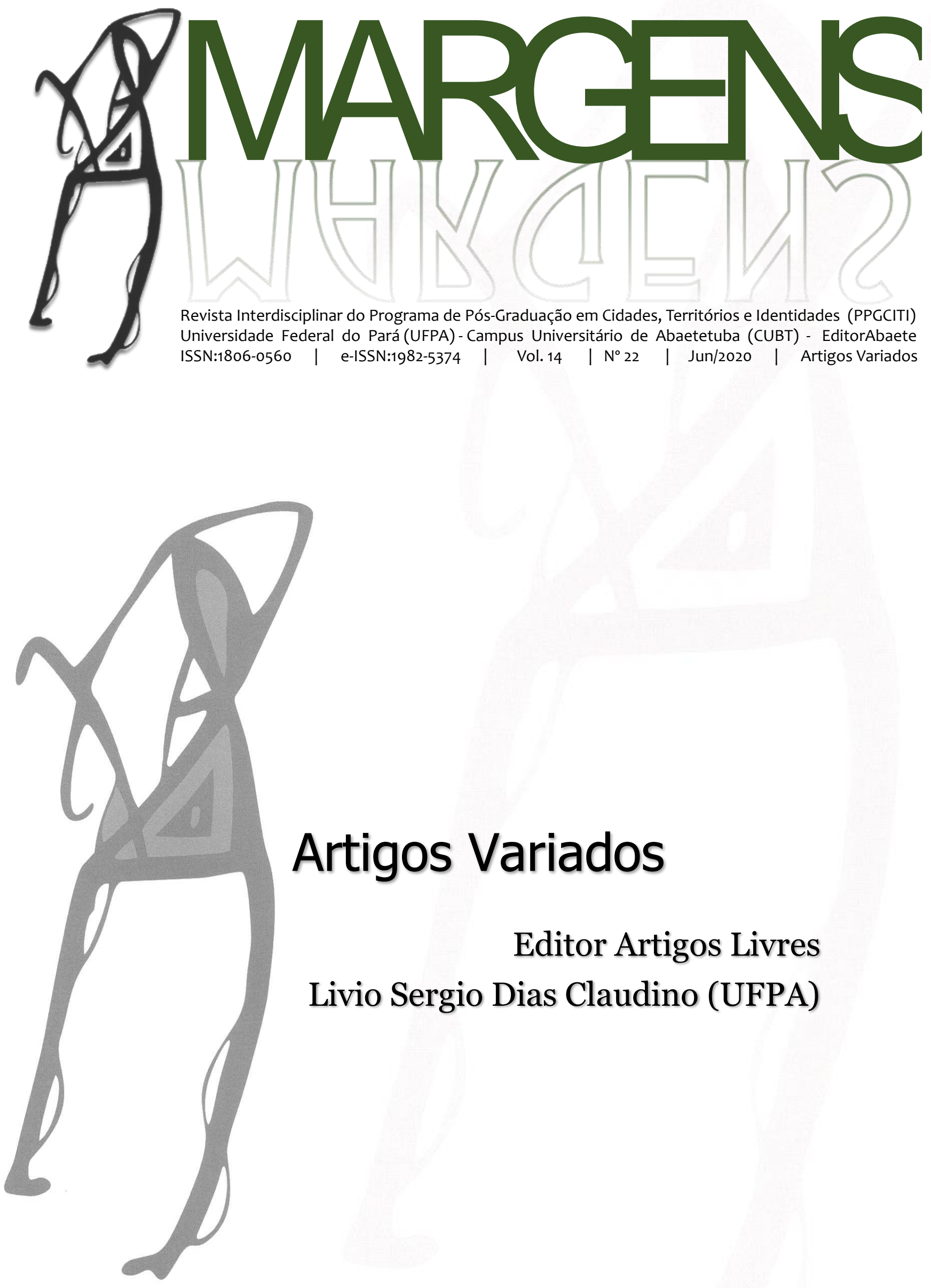


\section{Margens}

Revista Interdisciplinar do Programa de Pós-Graduação em Cidades, Território e Identidades (PPGCITI) do Campus Universitário de Abaetetuba/Baixo Tocantins/Universidade Federal do Pará

\section{Revista Margens - Vol. 14. N. 22 - Jun 2020}

Emmanuel Zagury Tourinho

Ana Aurea Barreto Maia

Osvaldo dos Santos Barros

Alexandre Augusto Cals e Souza

Lívio Sergio Dias Claudino (UFPA)

Raimundo Hosana Negrão

Reitor da Universidade Federal do Pará

Coordenadora do Campus de Abaetetuba

Coordenador da DPPG

Coordenador do PPGCITI

Editor-Chefe

Equipe Editorial Faculdade

Benilton Cruz

Dedival Brandão da Silva

Jadson F. Garcia Gonçalves

Joyce Otânia Seixas Ribeiro

Vivian da Silva Lobato

Mara Rita Duarte de Oliveira

Tiago Lemões

Conselho Científico

Alex B. Fiúza de Mello

Antônio Otaviano V. Junior

Bruno Pucci

Cristina Donza Cancela

Divino J. da Silva

Eduardo Pellejero

Eurípedes Funes

Flávio Bezerra Barros

Germana Maria Araújo Sales

Gilmar P. da Silva

Olgaíses Cabral Maués

Olga Von Simson Jaime Ginzburg

Jorge Larrosa

Josenilda Maria Maués da Silva

Kênia Rios

Ligia T. L. Simonian

Mardônio Silva Guedes

Márcio Danelon

Mário José Henchen

Maria dos Remédios de Brito

Nilza Brito Ribeiro

Pablo Esteban Rodiguez

Raimundo Nonato de O. Falabelo

Rafael Chambonleyron

Sandra Mara Corazza

Sinésio F. Bueno

Sílvio Gallo

Tânia Sarmento-Pantoja

Walter Omar Kohan
Faculdade de Ciências da Linguagem

Faculdade de Educação e Ciências Sociais

Faculdade de Educação e Ciências Sociais

Faculdade de Educação e Ciências Sociais

Faculdade de Educação e Ciências Sociais

Universidade da Integração Internacional da

Lusofonia Afro-Brasileira - ICEN-UNILAB

Universidade Católica de Pelotas

\section{Área/Instituição}

\section{Ciências Sociais/UFPA}

História/UFPA

Educação/UNIMEP/Piracicaba

Antropologia/UFPA

Educação/UNESP/Presidente Prudente

Filosofia/UFRN

História/UFC

Biologia/UFPA

Letras/UFPA

Educação/UFPA

Educação/UFPA

Ciências Sociais/ÚNICAMP

Letras/USP

Universidad de Barcelona/Espanha

Educação/UFPA

História/UFC

Antropologia/NAEA

História/Arq. Pub. Ceará

Filosofia/PUC/Campinas

Educação/UFPA

Educação/UFPA

Letras/UNIFESSPA

Universidad de Buenos Aires/Argentina

Educação/UFPA

História/UFPA

Educação/UFRGS

Educação/UNESP/Marília

Educação/UNESP/Campinas

Letras/UFPA

Educação/UERJ 
do https://periodicos.ufpa.br/index.php/revistamargens/article/view/9759

http://dx.doi.org/10.18542/rmi.v14i22.9759

Dados Internacionais de Catalogação da Publicação (CIP)

Biblioteca Central/UFPA, Abaetetuba, PA

Margens - Revista Interdisciplinar do Programa de Pós-Graduação em Cidades, Territórios e Identidades (PPGCITI) - Campus Universitário de Abaetetuba/Baixo Tocantins/UFPA - V. 14. N. 22 - Jun/2020 - Abaetetuba /PA: UFPA, 2020.

\section{Semestral}

Organizador: Livio Sergio Dias Claudino

Publicações em edições temáticas; V. 14. N. 22: Artigos Variados.

ISSN: $1982-5374$

Periódicos brasileiros. I. Universidade Federal do Pará (Campus Universitário de Abaetetuba/Baixo Tocantins) 


\section{SUMÁRIO}

APRESENTAÇÃO

ARTIGOS LIVRES

A TRAJETÓRIA DE UMA PARTEIRA DO ARQUIPÉLAGO DO MARAJÓ

Denise Machado CARDOSO, José da Silva RIBEIRO

APONTAMENTOS TEÓRICOS SOBRE AS PESQUISAS (AUTO)BIOGRÁFICAS E DE HISTÓRIAS DE VIDA E SUAS DIMENSÕES FORMATIVAS E EXPERIENCIAIS

Caio Corrêa DEROSSI, Karen Laíssa Marcílio FERREIRA.

TERRITORIALIZAÇÃO DE POLÍTICAS PÚBLICAS: APONTAMENTOS SOBRE A COVID-19 E O CÓDIGO DE ENDEREÇAMENTO POSTAL NAS FAVELAS CARIOCAS

André Luiz da Silva LIMA.

O DISPOSITIVO PEDAGógICO DAS REVISTAS CONTIGO! E ROLLING STONE EM RELAÇÃO A PABLLO VITTAR

Julian Junior dos Santos BARBOSA, Fernando ZOLIN-VESZ

"BANDIDO BOM É BANDIDO MORTO"? ANÁLISE DO DISCURSO CRÍTICA APLICADA A REAÇÕES SOBRE CHACINAS PUBLICADAS PELO JORNAL DIÁRIO ONLINE EM SUA PÁGINA NO FACEBOOK

Vivianne Carolina Oliveira de Sousa LEITE, Breno Rodrigo de Oliveira ALENCAR 66

\section{O MULTICULTURALISMO NA EDUCAÇÃO}

Bruno Freitas SANTOS 88

DINÂMICA ESPACIAL DE USO E OCUPAÇÃO DO SOLO URBANO NO MUNICÍPIO DE BREU BRANCO-PA.

Wagner Luiz Gonçalves da SILVA, Gilberto de Miranda ROCHA 
AS ORGANIZAÇÕES NÃO GOVERNAMENTAIS E O PROGRAMA CISTERNAS EM

BARREIRA (CE)

Victória de Sousa XAVIER, Andrea Yumi Sugishita KANIKADAN

\section{RESENHA}

Docência e pesquisa em formação de professores: primeiras aproximações ao objeto de estudo. Victor Hugo Nedel OLIVEIRA. 


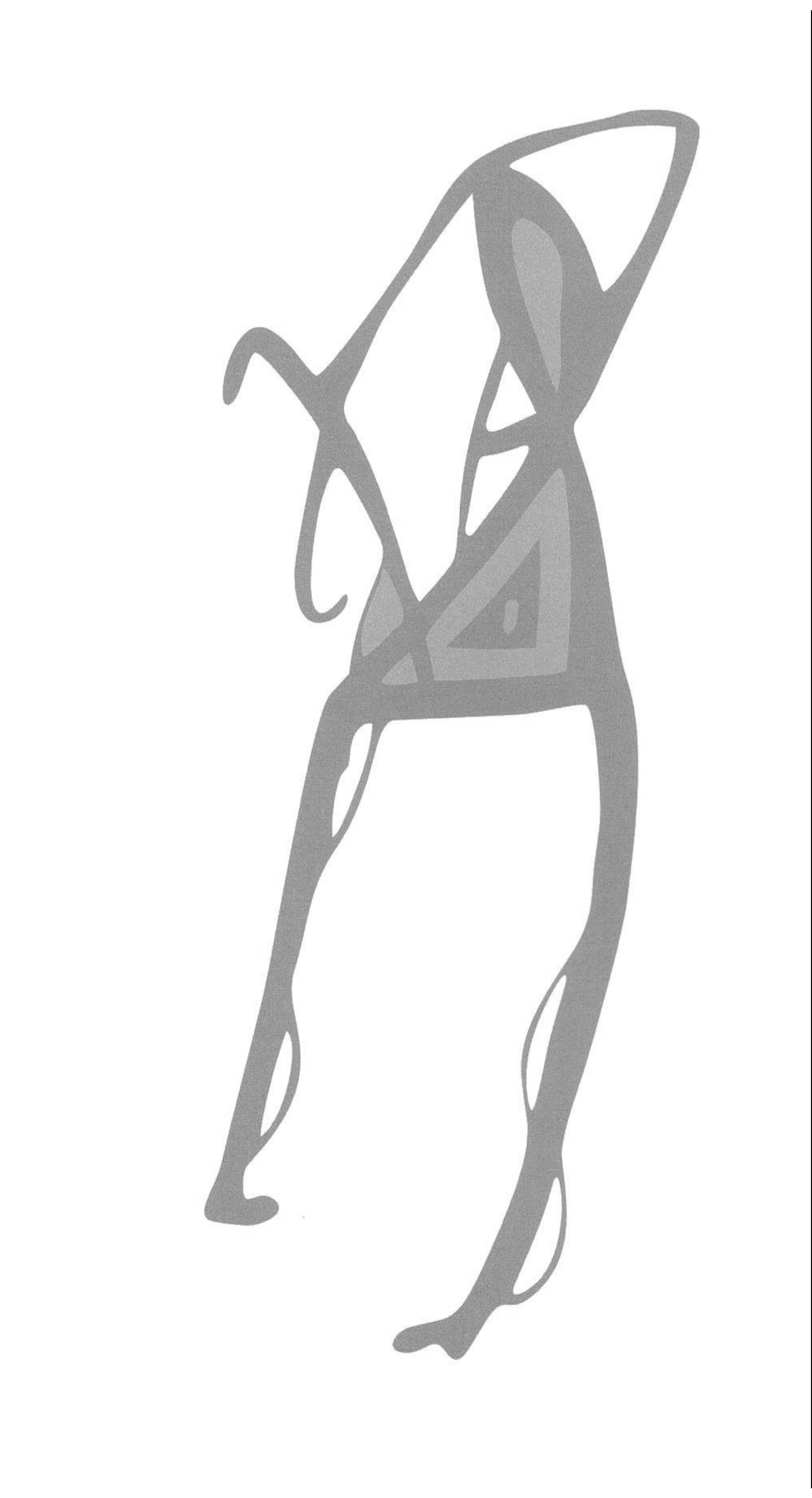




\section{APRESENTAÇÃO DE ARTIGOS VARIADOS}

\section{PRESENTATION OF VARIOUS ARTICLES}

Livio Sergio Dias Claudino ${ }^{1}$

Universidade Federal do Pará

Resumo: A presente edição da Margens: Revista Interdisciplinar do PPGCITI conta com oito artigos, e uma resenha. Trata-se de um número com Artigos Variados, que foram avaliados no processo duplo-cego, recebendo o parecer de pelo menos duas pessoas com expertise na área/tema dos textos. Em se tratando de um periódico Interdisciplinar, a Margens tem cumprido seu papel social e atraído pesquisadores de várias formações, com temas variados de diversos campos de conhecimento, oriundos de várias partes do país, conforme se pode conferir a seguir.

\begin{abstract}
This edition of Margens:
\end{abstract} Interdisciplinary Journal to PPGCITI has eight articles and a review. It is a number with Miscellaneous Articles, which were evaluated in the double-blind process, receiving the opinion of at least two people with expertise in the area / theme of the texts. As an Interdisciplinary journal, Margens has fulfilled its social role and has attracted researchers from various backgrounds, with varied themes from different fields of knowledge, from different parts of the country, as can be seen below.

\footnotetext{
${ }^{1}$ Doutor em Desenvolvimento Rural, Universidade Federal do Pará. E-mail: livio@ufpa.br
} 


\section{ARTIGOS VARIADOS}

A presente edição da Revista Margens Interdisciplinar conta com oito artigos, e uma resenha. Trata-se de um número com Artigos Variados, que foram avaliados no processo duplo-cego, recebendo o parecer de pelo menos duas pessoas com expertise na área/tema dos textos. Em se tratando de um periódico Interdisciplinar, a Revista Margens tem cumprido seu papel social e atraído pesquisadores de várias formações, com temas variados de diversos campos de conhecimento, oriundos de várias partes do país, conforme se pode conferir a seguir.

A edição é aberta com o belíssimo texto A trajetória de uma parteira do arquipélago de Marajó, de Denise Machado CORDEIRO e José da Silva RIBEIRO, o qual nos apresenta um registro etnográfico, baseado na oralidade, da trajetória de dona Maria Silva, uma das muitas parteiras do município de Melgaço, arquipélago do Marajó, Amazônia Brasileira, demonstra que os conhecimentos das parteiras são adquiridos de maneira tradicional e remetem à sua ancestralidade, apresentando grande relevância e garantindo práticas mais humanizadas durante o nascimento. A investigação de campo permitiu evidenciar que essas práticas se mantêm devido à maneira como o parto é assistido, proporcionando protagonismo à parturiente.

No segundo texto, Apontamentos teóricos sobre as pesquisas (auto)biográficas e de histórias de vida e suas dimensões formativas e experienciais, de Caio Corrêa DEROSSI e Karen Laíssa Marcílio FERREIRA, os autores refletem sobre alguns horizontes teórico-metodológicos das pesquisas (auto)biográficas no campo educacional, destacando as dimensões acerca das formações e das experiências. Realizam a discussão por meio de uma visão crítica sobre os pressupostos biológicos e exatos da ciência moderna, a produção e a construção de conhecimentos a partir do entendimento das (auto)biografias e das histórias de vida, conduzindo para os conceitos de formação e experiência, apontando perspectivas relacionadas aos caminhos e percursos da produção da pesquisa nas ciências humanas e na educação.

No terceiro texto, Territorialização de políticas públicas: apontamentos sobre a Covid-19e o código de endereçamento postal nas favelas cariocas, de André Luiz da Silva LIMA, o autor trata dos modos como a pandemia de Covid-19 revelou ainda mais as desigualdades sociais, e com isso a discussão em torno de políticas públicas e o papel do Estado ganhou espaço na esfera pública. O foco do texto é mostrar aqueles que vivem em localidades que não possuem o acesso adequado a serviços públicos básicos, e que são sistematicamente invisibilizados, inclusive no plano da estatística pública, como é o caso de localidades sem CEP (Código de Endereçamento Postal). Conforme discute o autor, 
não ter endereço com CEP, por logradouro, significa ter a existência - espacialmente falando - atrelada a outro lugar que não é onde se vive, e por consequência, com danos ao exercício da cidadania plena.

O quarto texto, O dispositivo pedagógico das Revistas Contigo! E Rolling Stone em relação a Pabllo Vittar, de Julian Junior dos Santos BARBOSA e Fernando ZOLIN-VESZ, analisa duas edições das revistas que tratam de assuntos sobre celebridades, publicadas em 2017 e 2018, que apresentam na capa a celebridade Pablo Vittar. Conforme argumentam os autores, as revistas apresentam práticas linguísticas em relação à cantora Pabllo Vittar que parecem desestabilizar o binômio masculino-feminino, constituinte do que se convencionou denominar língua portuguesa. Os resultados sugerem que as revistas funcionam como um dispositivo pedagógico que, por meio das práticas linguísticas relacionadas a Pabllo Vittar, nos ensinam modos outros de ser e estar no mundo social.

Já no quinto texto, "Bandido bom é bandido morto"? Análise do discurso crítica aplicada a reações sobre chacinas publicadas pelo jornal diário online em sua página no facebook, de Vivianne Carolina Oliveira de Sousa LEITE e Breno Rodrigo de Oliveira ALENCAR, os autores, por meio de uma abordagem da Análise do Discurso Crítico, apresentam os resultados de uma pesquisa sobre as reações de internautas ao noticiário da violência em redes sociais, em particular aquelas relacionadas às chacinas de Belém (2014), Tapanã (2018) e Guamá (2019) ocorridas na cidade de Belém e publicadas pelo jornal Diário Online (DOL) em sua página no Facebook. Buscam identificar os padrões de reações às manchetes; analisar a intencionalidade das manchetes do jornal e interpretar os significados sociais em torno de reações dos usuários das redes sociais sobre o fenômeno da violência urbana na cidade de Belém.

O texto $O$ multiculturalismo na educação, de Bruno Freitas SANTOS, apresenta uma discussão sobre o multiculturalismo educacional, trazendo reflexões sobre a relevância do multiculturalismo na educação. Utilizou revisão bibliográfica sobre o tema, indicando que a educação requer inúmeras ações e intervenções para que a mesma se torne ampla e plural, apontando a importância do respeito às diferenças, que vão desde as raciais, passando pelas éticas, culturais, sociais e religiosas.

O sétimo artigo do número, Dinâmica espacial de uso e ocupação do solo urbano no município de Breu Branco-PA, de Wagner Luiz Gonçalves da SILVA e Gilberto de Miranda ROCHA, nos apresenta Breu Branco, município localizado na microrregião do lago de Tucuruí, estado do Pará. Os autores relatam que ao longo dos anos o município experimentou um crescimento populacional acelerado, consequência da migração de pessoas oriundas de outras regiões em busca de trabalho e moradia próximos às obras da Hidroelétrica. Utilizam fontes cartográficas e 
sensoriamento remoto para a construção de mapas em três períodos 1996, 2006 e 2016. Os resultados obtidos mostram novas dinâmicas espaciais, como a duplicação da área urbana, saturação do núcleo projetado da cidade em direção ao norte, conversão de áreas de preservação permanente (APP) em ocupações, concentração imobiliária e especulação sobre novas áreas, do ponto de vista populacional, um aumento de $58 \%$ da população em vinte anos.

Já no oitavo texto, que encerra a seção de artigos, As organizações não governamentais $e$ o programa cisternas em Barreira (CE), de Victória de Sousa XAVIER e Andrea Yumi Sugishita KANIKADAN nos apresenta o Programa de Cisternas, implementado na região rural do município de Barreira (CE). Conforme indicam as autoras, na região, os problemas acerca do abastecimento de água são diversos, principalmente para as comunidades mais afastadas do centro da cidade. Por meio de pesquisa qualitativa, com técnicas de pesquisa bibliográfica e documental, além da aplicação de entrevistas às famílias participantes do programa, o trabalho buscou identificar em que medida a população-alvo foi beneficiada pelo programa, cuja iniciativa pertence a duas organizações não governamentais atuantes no local, uma nacional e a outra internacional. Como principais resultados, indicam que os programas trouxeram melhorias, tais como a facilidade e garantia no acesso à água, mas que demandam outras reflexões sobre aspectos financeiros, de gênero, políticos e de desenvolvimento local.

Fechamos o número com a resenha do livro organizado por Francisco Antonio Machado Araujo e Maria da Glória Duarte Ferro intitulado: Docência e pesquisa em formação de professores: primeiras aproximações ao objeto de estudo, da EDUFPI, Teresina, 2018. A resenha foi elaborada por Victor Hugo Nedel OLIVEIRA, nos informa que a obra teve como principal objetivo refletir sobre a produção de conhecimentos que possam se transformar em embasamento para a formação de estudantes de graduação, investigadores e professores em todos os níveis de ensino. Trata-se de uma obra que convida a uma empreitada de profunda necessidade na contemporaneidade, haja vista a constante necessidade de repensar as técnicas e métodos das didáticas e das reflexões sobre a práxis docente.

Encerramos essa apresentação com o convite à leitura dos textos, esperando que os mesmos possibilitem reflexões necessárias aos embates cotidianos, nos fortalecendo e dando esperanças em um contexto de tantas crises e a recente pandemia de Covid-19. 


\section{A TRAJETÓRIA DE UMA PARTEIRA DO ARQUIPÉLAGO DO MARAJÓ}

\section{THE PATH OF A PARTY OF THE ARCHIPELAGO OF MARAJÓ}

Denise Machado CARDOSO ${ }^{1}$

Universidade Federal do Pará-UFPA

José da Silva RIBEIRO

Universidade Aberta - UAB - Portugal

\begin{abstract}
Resumo: Os conhecimentos das parteiras são adquiridos de maneira tradicional e remetem às suas ancestralidades. No município de Melgaço, arquipélago do Marajó, Amazônia Brasileira, essa atividade possui relevância e garante práticas mais humanizadas durante o nascimento. A pesquisa sobre Maria da Silva, uma dessas parteiras, objetiva investigar sua trajetória e foi baseada na oralidade, na etnografia. A investigação de campo permitiu evidenciar que essas práticas se mantêm devido à maneira como parto é assistido, proporcionando protagonismo à parturiente.
\end{abstract}

Palavras-chave: Marajó. Parteiras tradicionais. Oralidade. Saberes Ancestrais.

\begin{abstract}
Midwives' knowledge is acquired in a traditional way and refers to their ancestry. In the municipality of Melgaço, Marajó archipelago, Brazilian Amazon, this activity has relevance and guarantees more humanized practices during the birth. The research on Maria da Silva, one of these midwives, objective aims to investigate its trajectory and was based on orality and the ethnography. Field research has shown that these practices are maintained due to the way in which birth is assisted, providing protagonism to the birthing woman
\end{abstract}

Keywords: Marajó. Traditional midwives. Orality. Ancestral Knowlegde.

\footnotetext{
${ }^{1}$ Doutora em Desenvolvimento Socioambiental (NAEA-UFPA). Professora da Universidade Federal do Pará. Coordena o Grupo de Estudos sobre Antropologia Visual e da Imagem (VISAGEM) e o Grupo de Pesquisa sobre Populações Indígenas 'Eneida Correa de Assis' (GEPI). Atua como Assessora Adjunta na Assessoria da Diversidade e Inclusão Social (ADIS-UFPA) e é membro do Comitê de Antropologia Visual da Associação Brasileira de Antropologia (CAV-ABA): denisecardosoufpa@gmail.com

${ }^{2}$ Doutor em Ciências Sociais-Antropologia pela Universidade Aberta de Portugal. Professor visitante da Universidade Mackenzie (Educação, Arte e História da Cultura), Universidade de Múrcia - Espanha (ERASMUS) e da Universidade de Savoie - França. Coordena o Grupo de Investigação antropologia visual /media e mediações culturais - CEMRI: Universidade Aberta: jsribeiro.49@gmail.com
} 


\section{Introdução}

As atividades desenvolvidas por parteiras são importantes na saúde reprodutiva de mulheres. O oficio de partejar é milenar e se mantem como relevante ainda nos dias atuais, pois contribui para o bem-estar e bem viver de mulheres em diferentes sociedades. No arquipélago do Marajó, região Norte do Brasil, as parteiras têm se destacado ao longo dos anos e perpetuam conhecimentos sobre a reprodução humana para além da medicina considerada oficial.

Nesta pesquisa sobre a trajetória de Maria da Silva, uma das mais antigas parteiras de Melgaço, município localizado no arquipélago do Marajó ${ }^{3}$, realizamos um estudo que enfatiza fontes históricas não convencionais, como é o caso de memórias de pessoas ou de grupos sociais. A pesquisa bibliográfica também foi importante na condução desta investigação sobre o oficio de parteiras, inspirados na compreensão e inclusão de conhecimentos ancestrais sobre o ato de partejar e os desafios desse oficio em tempos atuais e pretéritos. Assim, desenvolvemos uma pesquisa pautada na valorização de conhecimentos outros além daqueles consolidados no âmbito acadêmico.

A pesquisa de campo contou com o suporte metodológico da Antropologia, pois utilizamos a etnografia como uma ferramenta para subsidiar o diálogo etnográfico (RIBEIRO, 2005). Como procedimento metodológico exploramos, ainda, a História Oral a partir dos relatos orais como fonte desta pesquisa por considerar que estes são, dentre outras fontes não convencionais, elementos relevantes para questionar uma visão monocultural da memória.

As conversas informais e entrevistas semiestruturadas se apresentaram com uma oportunidade de diálogo profícuo. E tal como indicado por Ana Canen e Libânia Xavier (2000), os relatos orais são uma importante forma de valorização da diversidade social, de gênero, e de outras culturas na construção de uma memória mais ampla, ou seja, uma perspectiva intercultural crítica.

Gayatri Spivak (2010) também emerge como importante inspiração no trato metodológico, pois apresenta o questionamento se subalternos e subalternas podem falar, ela reitera aquilo que os estudos atuais sobre as regiões antes colonizadas, e em outras ainda marcadas por conflitos de classe, estão buscando conquistar. Para além da hegemonia dos saberes, propõem-se novas epistemologias, novas abordagens, outras perspectivas, e outros saberes.

\footnotetext{
${ }^{3} \mathrm{O}$ arquipélago do Marajó está localizado no estado do Pará e é formado por duas microrregiões: a região do Arari, que comporta os municípios de Cachoeira do Arari, Chaves, Muaná, Ponta de Pedras, Salvaterra, Santa Cruz do Arari e Soure; e a região do Furo de Breves, a qual compreende aos municípios de Afuá, Anajás, Breves, Curralinho, São Sebastião da Boa Vista e Gurupá.
} 
Neste estudo em particular, propusemos instigar discussões sobre o partejar, enfatizando-se a perspectiva de uma mulher parteira, seus costumes, saberes e fazeres. A partir das narrativas sobre sua trajetória de vida desta mulher apresentamos suas experiências e memórias que se cruzam, criando laços que atravessam gerações. Na medida em que o fazer dessa parteira traz novas vidas ao mundo, conta a história de um povo, reforça suas crenças, expõe suas emoções, define relações sociais e reafirma a identidade sociocultural coletiva, e suas narrativas se tornam importantes elementos para a compreensão de seu próprio grupo social.

Procuramos responder às seguintes indagações: O que uma mulher de grupo subalternizado tem a dizer para a academia? De que maneira podemos aprender com mulheres parteiras? Como se dá a interface entre conhecimentos destas mulheres e aqueles da chamada Medicina Oficial? A partir da trajetória de Dona Maria da Silva, quais desafios as parteiras enfrentaram, e enfrentam, no exercício de seus trabalhos? Ainda, cabe enunciar a importância de compreender como elas veem a si mesmas e como outras pessoas envolvidas (direta ou indiretamente) nos processos de partejar as veem. Por certo, a pesquisa de cunho qualitativo anuncia-se como uma adequada estratégia de investigação, pois nos permite levantar questões que não dizem respeito apenas à trajetória de Dona Maria.

O artigo está estruturado em três partes: na primeira apresentamos considerações teóricas sobre memória e suas múltiplas dimensões, enfatizando a memória e suas implicações entre lembranças e esquecimentos. Apresentamos a escolha para navegarmos por rios da Amazônia para realizar o que fora proposto como projeto de pesquisa e de extensão em Melgaço. Em seguida apresentamos a trajetória de Dona Maria ao longo de sua vida em diversos municípios da região do Marajó, e seus relatos sobre suas experiências como parteira nesta região. E concluímos com considerações finais sobre os diálogos estabelecidos com Dona Maria da Silva.

Apresentamos neste artigo alguns elementos biográficos dessa mulher e seus conhecimentos acerca do ato de partejar, sua vivência nos cuidados tradicionais com a saúde da mulher e suas interfaces com a chamada medicina oficial. Embora já tivéssemos um roteiro pré-definido, dialogamos com Dona Maria a cada dia de encontro sobre o que seria tratado naquelas tardes chuvosas, com conversas na cozinha de sua casa e regadas ao sabor de seu café acompanhado de bolo. 


\section{Os caminhos que nos levaram a Melgaço, no arquipélago do Marajó}

A escolha pelo município de Melgaço para desenvolver projeto pesquisa e de projeto de extensão se deu a partir da junção de alguns fatores. Um deles era o fato de haver em Melgaço de Portugal um festival anual de cinema e, por isso, pensou-se em proporcionarmos uma aproximação entre gestores, instituições e moradores destes municípios homônimos a partir da produção fílmica.

O projeto de pesquisa sobre parteiras surgiu como um subprojeto do Projeto de Extensão “Incursões Etnográficas em Melgaço do Marajó-Amazônia Brasileira”. Esse projeto de extensão era voltado para práticas além muros das universidades, e consistiu em oferecer ao grande público aquilo que é produzido no âmbito acadêmico. Ele foi elaborado a partir do interesse em consolidarmos parceria entre equipe de docentes e discentes da Universidade Federal de Goiás e da Universidade Federal do Pará. O objetivo central nesse projeto era o de realizar oficinas de audiovisual com jovens e crianças, para a produção de filmes com a utilização de câmeras fotográficas e telefones celulares. Além disso, promovemos a I e II Mostra de Cinema Juvenil e produção de documentários sobre pessoas de destaque no município, a partir de suas práticas e saberes, respectivamente nos anos de 2019 e 2020.

Desenvolvemos como subprojeto a investigação sobre trajetórias de vida, sempre incorporando o uso da Antropologia Visual, pois na pesquisa de campo com a utilização de imagem, ela se apresenta tanto como um produto de pesquisa quanto um meio para a elaboração de informações feitas a partir da investigação. Aos usos da etnografia, na qual se destacam as conversas informais e a observação direta; somaram-se o registro fotográfico e audiovisual, e todo o processo subsequente de edição.

Além dos procedimentos da Antropologia utilizamos aqueles inerentes à História Oral porque a partir da oralidade, e de outras expressões, seria possível termos acesso às narrativas sobre a trajetória de Dona Maria por ela mesma. Cabe destacar que segundo Maria de Lourdes Janotti e Ricardo de Paula (1988), na História Oral a memória é trazida pelos relatos orais e envolve uma carga emocional forte que interfere na narrativa e na sua interpretação. Desse modo, a subjetividade presente nesses relatos permite perceber valores, crenças e tradições. Consequentemente, as memórias acessíveis de Dona Maria muito nos dizem sobre as memórias de si, entremeadas com aquelas que se consideram como de toda a coletividade.

Ainda sobre os procedimentos relativos à Antropologia, o interesse em produzir um documentário sobre a trajetória de vida de uma parteira, reconhecidamente importante para o município, foi iniciado em 2018 na oportunidade em que conversamos com lideranças locais e nessas 
oportunidades muito se falou sobre as mulheres que realizam acompanham outras mulheres no partejar. Nesse contexto, percebemos o potencial de registro fílmico dos relatos orais realizados a partir de conversas informais desta importante parteira que vive em Melgaço, no arquipélago marajoara.

Sobre o local da pesquisa, pode-se afirmar que Melgaço é um município que se caracteriza por apresentar um ambiente natural marcado pela influência de seus rios e florestas na dinâmica de quem nele vive. Localizado no Arquipélago do Marajó, tem população estimada de 26.642 habitantes, segundo o Instituto Brasileiro de Geografia e Estatística (IBGE), no ano de 2016. Considerando a situação de pobreza, e o difícil acesso à sede/cidade, que atualmente detém um baixo Índice de Desenvolvimento Humano (IDH), as condições de saúde e assistência ao parto levam à criação de alternativas aos métodos institucionalizados de saúde. Neste cenário, as parteiras são elemento fundamental na assistência ao parto, embora outros motivos marcam a opção por estas mulheres pela parturiente.

No ano 2000 o Ministério da Saúde cria o Programa Trabalhando com Parteiras Tradicionais, buscando valorizar os saberes e práticas tradicionais e caracterizar a sua formação e o conhecimento que elas já detêm, considerando as especificidades étnicas e culturais, e articulando seus saberes com o saber científico.

Nesse contexto, a pesquisa sobre a trajetória de vida de Maria da Silva e a produção de um documentário com essa temática são maneiras de valorizar os fazeres e histórias de vida das parteiras de Melgaço (Pará). A partir desse estudo com Dona Maria, registra-se a importância dessas mulheres para as comunidades onde vivem, as relações, laços e conflitos que permeiam o ato de partejar.

Os artefatos para o registro fílmico, as câmeras fotográficas e o recurso para captação de som durante nossas conversas, pouco inibiram as narrativas apresentadas. Ao que tudo indica, tornou-se uma situação de partilha e de estarmos juntos na construção de conhecimento; de melhor aprendizagem sobre a reprodução humana, contracepção, nascimento e os cuidados com a vida; de troca de saberes locais, populares com saberes institucionais - da academia, das instituições de saúde.

Ressaltamos, ainda, que a memória de Dona Maria entrelaçada com aquelas de sua família, e em especial de seu esposo, exigiu o tratamento pela perspectiva de que as lembranças dizem respeito ao grupo ao qual haja pertencimento, ou seja, a memória como algo coletivo, tal como indicado por Halbwachs (2003). As conversas foram a oportunidade de trazer à tona as lembranças de um tempo, de uma trajetória, e de uma sociedade marajoara que ressignifica seus conhecimentos em práticas atualizadas tradicionalmente. 
A memória coletiva se expressa como um aspecto relevante da sociedade desta parte do arquipélago do Marajó, mas não se restringe a esse espaço geográfico porque traz elementos culturais dos modos de vida dos povos e populações ribeirinhas da região Amazônica.

\section{3 "Pra começo de conversa": Memórias de uma mulher que cuida de mulheres}

A proposta de trabalhar com narrativas de parteiras, implica em considerar as suas memórias, com lembranças e com seus esquecimentos, com as memórias individuais que revelam condições de coletividade, uma memória histórica do grupo ao qual estão inseridas, tal como evidenciado por Maurice Halbwachs (2003). Assim o percurso metodológico indicado para este estudo envolve, em muitos casos, o que fora indicado por Vânia Cardoso (2012) em termos de estudos sobre biografias.

Para esta autora, o contar estórias não se refere apenas à produção de conhecimento como um possível acúmulo de dados. Ao contrário, ocorre algo dinâmico, posto que o fazer e o refazer vão sendo incorporados ao longo das narrativas. Assim, contar estórias de si ou de outrem, é um reelaborar e ressignificar fatos e situações, conforme as lembranças vão sendo acionadas e expressas. Desse modo, cabe destacar a perspectiva indicada por Catherine Walsh (2000) na qual

Alenta novos processos, práticas e estratégias de intervenção intelectual que poderiam incluir, entre outras, a revitalização, revalorização e aplicação dos saberes ancestrais, não como algo ligado a uma localidade e temporalidade do passado, mas como conhecimento que tem contemporaneidade para criticamente ler o mundo e para compreender, (re) aprender e atuar no presente (WALSH, 2000, p. 12)

Propomos assim, buscar a compreensão acerca do modo de atuação e percepção de uma parteira sobre o partejar.

Os estudos sobre mulheres parteiras são significativos em diferentes áreas de estudo. Tal produção indica, por exemplo, que as transformações na prática do partejar foram ocorrendo devido ao avanço da chamada medicina convencional, e impactou não apenas nas práticas relativas ao parto, como também nas representações e visões que se tem acerca das mulheres parteiras. Interessante notar, também, que os estudos que tratam dessas dinâmicas foram realizados pela História, pela Medicina, pela Demografia, pela Enfermagem e pela Antropologia, reforçando a relevância do tema no âmbito da pesquisa científica.

Imbuídos pelo interesse em pesquisar os conhecimentos ancestrais de parteiras organizamos uma proposta de estudo que envolvesse, predominantemente as memórias de parteiras, pois o partejar é algo interessante tanto em termos de estudos históricos e sócio antropológicos, estudos da área de 
saúde sobre práticas de cuidados corpóreos, além das pesquisas e propostas no âmbito de políticas públicas sobre saúde em seus vários aspectos.

A obra de Soraya Fleischer (2011) produzida a partir de sua pesquisa antropológica na região do arquipélago do Marajó, e a de Joana Pedro (2003) subsidiaram a pesquisa bibliográfica em nosso projeto. Destacamos que o trabalho de Joana Pedro (2003), embora trate da questão do parto no contexto do silenciamento e rapidez no processo devido à gravidez indesejada no Brasil (início do século XX), traz o debate sobre contracepção, aborto e infanticídio a partir de estudos documentais referentes a este período. O trabalho de Emily Martin (2006) em Maryland, nos Estados Unidos, também é um dos incentivadores para a realização desta pesquisa, pois tal como havíamos proposto ela enfatiza a visão de uma mulher parteira, na medida em que seus estudos indicam a relação do parto com resistência, raça e classe social.

O contato inicial com Dona Maria da Silva ocorreu no ano de 2018 quando planejamos o projeto de pesquisa sobre conhecimentos de mulheres e acerca dos cuidados com saúde e suas bases em conhecimentos ancestrais. Precisamente, iniciamos a investigação no arquipélago do Marajó, no município de Melgaço. A partir de indicação de Izaias Correa Guedes (assessor da prefeitura deste município). Como estávamos interessados em produzir um vídeo sobre o trabalho de parteiras ele nos levou até a casa de Dona Maria e começamos nossa pesquisa utilizando, predominantemente, procedimentos da História Oral, sem deixarmos de lado as práticas etnográficas desenvolvidas em outros estudos. $\mathrm{O}$ interesse em conhecer mais sobre sua biografia foi crescendo ao longo dos meses seguintes até se transformar em projeto de pesquisa mais consistente.

Após o primeiro contato em 2018, retornamos a Melgaço em 2019 com o objetivo de retomar o contato e desenvolver o projeto da biografia, dentre outros temas. O reencontro ocorreu novamente em sua casa quando a procuramos com a proposta de desenvolver um trabalho sobre sua vida. Animados diante do aceite de Dona Maria, passamos a frequentar sua casa para as conversas consigo, além de observar sua vivencia cotidiana como parteira.

As conversas ocorriam sempre à tarde, na cozinha de sua casa, e durante esses momentos era ela quem estabelecia o que seria tratado naquele dia. Ao término desses encontros diários tomávamos café juntas com a equipe da pesquisa e com seus familiares. Em certas ocasiões ele mostrava fotografias, material técnico, documentos, contribuindo para o fluir das respostas que nos dava diante de nossa curiosidade acadêmica, mesclada com curiosidade pessoal, sobre a vida desta mulher.

O que se segue são alguns aspectos dessa pesquisa, cujo projeto é intitulado "Parteiras: práticas e saberes". Em sua trajetória há vários elementos que indicam o modo de vida ribeirinho da região amazônica, em especial das pessoas que vivem nos municípios do Marajó. 


\section{Dona Maria da Silva, trajetória de vida}

Nascida no município de Afuá, também no Marajó, Maria da Silva tem oitenta e quatro anos de idade e está casada, atualmente, com Gerônimo (oitenta e oito anos). Criada pela avó materna, pois ficou órfã ainda cedo, trabalhou desde os onze anos na extração de madeira e fabricação de dormentes ${ }^{4}$. Já adulta, passou a trabalhar com extração do látex de borracha das inúmeras seringueiras (Hevea brasiliensis) desta região. Além disso, extraía o leite de Açacu (Hura crepitans), atividade que quase a deixou cega. Posteriormente, passou a atuar na extração de palmito da palmeira de açaizeiro (Euterpe oleracea). Durante longos anos esteve ligada ao que ela denomina como "trabalho com madeira", seja extraindo as resinas ou com recursos madeiráveis.

Ainda jovem casou e teve onze filhos, mas, desses, quatro faleceram e ficaram três filhas e quatro filhos. Apenas um mora distante, pois mudou-se para Santana, no Amapá (Estado vizinho do Pará). Os demais filhos moram em Melgaço ou em municípios vizinhos. Para Dona Maria, todos querem ficar perto, mas se vão por que precisam trabalhar. Eles são muito "agarrados" à mãe, confidenciou-nos, e o mesmo se observa com seus netos e netas, e bisnetas, sempre em visita à sua casa.

Dona Maria conta de suas dificuldades e desafios para criar os filhos, pois seu primeiro esposo era aleijado de uma perna e se movia com dificuldades. Devido à essa deficiência ela diz que ele pouco auxiliava na criação dos filhos, seja na obtenção de renda ou nos cuidados com a casa e com as crianças. Ela assim descreve a situação: "Ele não trabalhava como eu. Eu saia e levava as crianças pequenas comigo para o mato".

Após seu falecimento, ela ficou viúva por alguns anos até conhecer seu atual marido. Nesse interim, embora diminuíssem as dificuldades financeiras e seu trabalho nas atividades extrativistas nas florestas ficassem cada vez mais esparsos, o "trabalho na roça" com atividades de cultivo de mandioca (Manihot utilisima) e diversas frutas foi mantido ao longo dos anos.

É importante salientar que em suas lembranças desde os tempos de sua infância, passando pelos momentos de seu primeiro casamento, o que Dona Maria traz de modo mais enfático é a superação diante dos desafios e dificuldades por ela enfrentados. Em alguns momentos de nossas conversas ocorridas em 2018, Dona Maria verbaliza a satisfação em ter criado seus filhos e hoje ter uma vida mais tranquila e confortável. Segundo nos relatou:

\footnotetext{
${ }^{4}$ Cada uma das peças de madeira, de metal ou de cimento armado, colocadas no solo, perpendicularmente à via férrea, e em cima das quais são fixados os trilhos.
} 
Hoje tenho sandálias para calçar, tenho rede para dormir, tenho comida na panela. Mas, antes, quando era criança, andava descalça porque não tinha um par de chinelos para calçar, não tinha roupas porque antes tinha que comprar tecido e mandar fazer na costureira.

Ela reflete sobre o momento atual seguindo um raciocínio baseado na comparação entre o ontem e o hoje. E explica que há mais facilidade para comprar as coisas de casa e para si. O tempo anterior, de sua infância e juventude, foi aquele marcado pelas dificuldades não apenas para si, mas para praticamente todas as pessoas pobres. Com isso, ela nos permite refletir sobre processos de dinâmica social, e principalmente sobre níveis diferenciados de pobreza.

A História Oral se apresentou como um importante instrumento nesses momentos da pesquisa porque ela se utiliza de uma metodologia que enfatiza a memória (FREITAS, 2002). Ao observarmos o diálogo com Dona Maria, notamos que o que é trazido oralmente não segue a ordem cronológica e não se refere somente daquilo que é lembrado. Além disso, nos silêncios entrecortando as falas, nas expressões faciais e corporais, e no tom de voz, percebemos que os esquecimentos também fazem parte constitutiva das memórias individuais e coletivas.

\section{Esse é um dom que Deus me deu!}

Sobre seu trabalho como parteira, Dona Maria relata que começou aos vinte e cinco anos quando uma tia precisou de sua ajuda na hora do parto. Sozinhas tiveram que ajudar uma a outra nesse momento de trazer uma criança ao mundo. A partir de então, foi paulatinamente sendo acionada por outras mulheres quando ainda morava no município de Breves. Desde então, passou a desenvolver o que atualmente ela considera como um dom, um dom de Deus.

Ao longo dos tempos foi adquirindo mais experiência, conhecimento técnico e pela vivência como parteira. Atuante em termos de organização da categoria, fundou em 24 de agosto de 2000, juntamente com outras parteiras, a Associação de Parteiras Tradicionais de Melgaço (ATPM). Mas, devido ao falecimento de algumas mais velhas e pelo reduzido envolvimento das demais parteiras desse município, a ATPM está enfraquecida como entidade que as articula profissionalmente.

Ao descrever suas atividades demonstra inúmeros saberes sobre acompanhamento das parturientes para um parto mais tranquilo e conforme as preferências de local e modo de ter uma criança. Ela conhece como poucas pessoas a maneira de identificar o sexo biológico ainda nos 
primeiros meses de gestação. Sabe tratamentos para aliviar dores, contrações e tantas outras situações que envolvem gestação e parto.

A partir de 2000 participou de vários cursos e atividades de capacitação, inclusive em outros estados brasileiros. Ao falar desses cursos, Dona Maria foi ao seu quarto e retornou trazendo alguns dos equipamentos que foram adquiridos quando participou de cursos e treinamentos para aprimorar sua prática como parteira, incorporando outros conhecimentos médicos.

Segundo ela ainda nos relatou sobre o que considera como o marco inicial para o reconhecimento como parteira pela prefeitura foi o convite para participar de evento voltado para realização de parto e outros temas correlatos à saúde sexual e reprodutiva das mulheres. Assim ela descreve o convite para sua primeira participação naquilo que ela denomina como concurso:

- Foi no tempo do Casemiro. Foi em 2000 que nós fomos fazer o primeiro concurso. Eu estava em casa, era mais cedo que isso, era umas quatro horas, e o Judá chegou lá em casa. Não sei se a senhora conhece, ele trabalha com o pessoal da prefeitura. - Ele chegou em casa e disse: Ei Velha! (ele só me chama de velha).

- Velha não! Eu disse.

- Bora passear! Tu queira ou tu não queira, velha, tu vais passear. Vamos Dona Maria, a senhora vai passear, a senhora não fica. Olha! vai você, vai a Dona Doca, vai mais cinco ou seis parteiras, tantas quantas quiserem ir, quantas que puderem ir.

- Eu disse: quando é que a gente vai?

- Ele disse: é hoje!

- Mas, já? Vocês chamam em cima da hora

- Já velha! Ponha uma redinha numa sacola velha... Vamos sim, mais tarde venho te buscar.

- Aí perguntei pro velho: eu vou? Ele respondeu: vai, se é pro teu futuro.

- Fomos para Caxiuanã! Dona Bené também foi. Muito bonito Caxiuanã ${ }^{5}$.

- Já pensou fazer o útero da mulher com o barro? Já pensou fazer os ovários de barro?

Era umas trinta e pouca pessoas.

- Primeiro dia foi palestra, depois usaram barro para fazer o útero e ovários. Eu ficava só olhando, ficava só espiando.

- Todo mundo vinha espiar os meus, depois tiravam fotos e pediram para explicar. Algumas faziam só as xoxotas, mas não tinha nada dentro.

- Eu fiz o útero igual a um abacate e expliquei como funcionava. Eu olhava as outras e não falava nada. E dizia: estou aqui para aprender.

- Foram cinco dias. Cada um dos cinco dias eles faziam uma coisa.

Ao longo de sua narrativa sobre esta primeira atividade de capacitação, contou que os temas eram voltados para identificação da localização da cabeça da criança no útero da mãe, do tempo de gestação e da maneira como tratar uma mulher no momento do parto. Principalmente, a posição da mulher para ter neném. Nesse aspecto, assim ela detalhou o diálogo entre ela e a pessoa que atuava como instrutora:

\footnotetext{
${ }^{5}$ Caxiuanã é uma região do município de Melgaço onde funciona a Estação Científica Ferreira Pena, do Museu Paraense Emilio Goeldi.
} 
- E aí Dona Maria, qual sua posição para moça do primeiro filho?

- Então eu disse: Não tem posição, a posição quem procura é ela.

- Se ela quiser em pé, é em pé. Se ela quiser de cócora, é de cócora, se ela quiser sentada ela tem, se ela quiser deitada ela tem... quando chegar a hora não tem.

- Se tiver um bacio, primeiro eu coloco o bacio e a criança arria mais ligeiro porque ela fica apoiada pra baixo, não fica apoiada por cima.

- Quando a bolsa estoura a cama já está preparada. A criança vem e eu pego.

Não boto pedaço de tijolo porque maltrata isso aqui da coluna da mulher, aí fica uma mulher doente.

- Ela levanta, faço o asseio, vai deitar na cama ou na rede.

Após essa descrição ela lembra que no livro constam apenas fotos de suas ações neste curso. Segundo ela declarou isso ocorreu porque ela não "trabalha escandaloso" no momento do parto. Sua explicação foi enfatizada quando chamou atenção para o que ela apresenta como comentários da equipe do treinamento: "A senhora trabalha bem. A senhora é dom que Deus lhe deu. A senhora tem jeito, quando a criança sai a senhora já vai embrulhando e a mulher vai se desocupando e já vai fechando ela".

Dona Maria ponderou que além da mulher escolher a posição ideal para o parto, é importante cuidar dela logo após a chegada da criança. Segundo ela, após o asseio a mulher precisa ser fechada (referindo-se ao fato de estar com as pernas abertas para saída da criança). Para Dona Maria, "Se a mulher fica aberta, e se pegar um vento, já vai pegar uma doença”. Assim, os cuidados são detalhados em termos dos vários momentos do partejar.

O caminhar facilita o posicionamento ideal para a saída da criança, por isso Dona Maria aconselha que seja a mulher a escolher o momento e posição para o parto. Ela relata que em alguns ela caminha com a parturiente pelo quarto porque assim ela terá melhores condições para indicar se está, ou não, preparada para o nascimento da criança.

Nesses e em outros casos em que a mulher é iniciante, a calma e tranquilidade são essenciais para o trabalho dela e da parteira. Em suas lembranças ela traz casos de cuidados diferenciados dados a estas mulheres e indica como elemento central no trata com as iniciantes é o amor que tem em sua atividade como parteira: "Eu tenho muito amor quando vou fazer um parto. Quando é moça do primeiro filho eu rezo, eu agrado...Todo amor que a mulher tem o filho e ninguém ouve. Não se ouve barulho, só o choro da criança".

Assim, além das questões de conhecimentos adquiridos com a experiência em realizar diversos partos, é importante ressaltar que aspectos outros são incorporados nesta prática. Desse modo, o que indica Spivak (2010) acerca do falar de pessoas subalternizadas também necessita ser incorporado. O saber da medicina oficial/convencional não é de todo descartado pelas parteiras, mas 
o que dizer de profissionais que atuam em hospitais e maternidades acerca dos conhecimentos das parteiras? Será que elas são ouvidas e consideradas em seus saberes? Elas estão podendo efetivamente falar sobre o que adquiriram em termos de suas expertises baseadas em práticas empíricas? Essa questão sobre a subalternização de mulheres parteiras foi uma constante nessa pesquisa.

A problemática em torno da subalternização de mulheres parteiras já fora analisada em diversos trabalhos acadêmicos que demonstram como o tratar da saúde de mulheres foi sendo alterado pela chamada medicina oficial. Contudo, os saberes e práticas do partejar sustentado pela ancestralidade que as mulheres trazem em seus conhecimentos sobre si, sobre seus corpos, ainda é algo intenso e usual, principalmente em áreas onde o acesso à rede pública de saúde é precário, como é o caso de municípios do arquipélago do Marajó.

Diante dos desafios presentes no sistema oficial de saúde e por opção em adotar procedimentos com parteiras, as mulheres de Melgaço, principalmente aquelas em sua primeira gravidez ou com dificuldades ao longo dos meses de gestação, procuram o acompanhamento de outras mulheres para ter sua criança. Durante a realização da pesquisa de campo, Dona Maria foi procurada por uma jovem para certificar-se sobre o desenvolvimento de sua gravidez. Nessa oportunidade, e para manter a discrição desse momento, apenas uma mulher da equipe pode acompanhar o atendimento e a conversa que ocorreu em um dos quartos da casa.

Essa situação nos fez refletir sobre os interditos e as prescrições que envolvem uma pesquisa de campo, notadamente no âmbito da Antropologia, pois nem sempre somos aceitos nos grupos ou incorporados ao evento que é tema de investigação. Por questões de gênero, geração, situação do corpo, aspectos do próprio evento, entre outras, somos apresentados às limitações, a desafios e aos imponderáveis da pesquisa de campo. Por certo, o fato de estarmos numa equipe onde participam pessoas de diferentes perfis, contribuiu para avançarmos em determinadas circunstâncias e recuarmos em outras. De todo modo, trabalhar o tema sobre o parto já era sabido entre nós que em vários momentos desta pesquisa caberia a interlocução apenas entre mulheres.

A procura pelo atendimento com Dona Maria não significa que as mulheres não irão se interessar em serem atendidas também por profissionais da biomedicina. Assim como ocorre em outros casos, a complementariedade entre saberes e práticas é recorrente, ou seja, não há exclusão desse ou daquele modo de garantir um bom parto e saúde para a parturiente e suas crias. Mesmo após o parto há que se cuidar da vida com a atenção básica nos postos de saúde e com os procedimentos no resguardo.

Dona Maria relata, ainda, uma história de "criança encruada", ou seja, quando há demora no parto devido aos esforços físicos para o nascimento. Quando a espera pela hora do parto ocorre em 
mulheres que tem filho pela primeira vez é importante o uso do óleo doce (óleo de amêndoas) para massagear a barriga e para hidratar o canal vaginal.

Sobre o exame de toque ela nos descreve como fundamental para saber se é caso de parto natural ou se será parto com faca (maneira de definir parto cesariano). A partir de nossos questionamentos ela explica como procede: "Meto a mão na luva, passo o dedo no óleo de amêndoas, se varar o dedo é caso de parto para parteira, mas se apertou, não. Não tem quem faça, é caso de faca”. Ela conclui sua explicação sobre o exame de toque dizendo: "É muita ciência sim para parto de primeiro filho". Assim, se tiver espaço não precisa o parto Cesárea. Por isso, muitas são as mulheres que a procuram, para saberem se é caso de acompanhamento com parteiras ou caso de médico.

Outro tipo de parto que as parteiras não fazem se dá quando são gêmeos, ou seja, ela afirma que não fazem partos porque as crianças estão entrelaçadas. O risco desse tipo de parto decorre do fato de que "Gêmeos ninguém sabe se um braço está trançado no outro, ou se uma perna está trançada na outra". E conclui: "Nós parteiras não podemos fazer". Afirmar de modo categórico: "Se apertou e sentiu duas crianças não procure mais", e finaliza nossa série de conversas afirmando: "Esse foi o dom que Deus me deu! ".

\section{Conclusão}

As parteiras são mulheres possuidoras de conhecimentos ancestrais, de técnicas e do respeito dado por outras mulheres em suas comunidades. Aprenderam com suas mães e avós a reconhecer o poder da natureza e das divindades; a utilizar as ervas e as rezas; a exercer a caridade e irmandade ao estarem disponíveis a qualquer hora do dia ou noite; a ter paciência e esperar o momento certo para a mulher e a criança; a ensinar às mulheres como cuidarem de si mesmas.

Nesse contexto, a trajetória de Maria da Silva é exemplar, pois é parteira em Melgaço, embora tenha iniciado essa prática e oficio no município de Breves, foi naquele município que desenvolveu suas habilidades e conhecimentos sobre o ato de partejar.

Os estudos sobre mulheres e suas práticas relativas à sexualidade, reprodução, partejamento, concepção e contracepção, reforçam o viés antropológico naquilo que se refere à etnografia. Quando se inclui a possibilidade de aprender com elas, realizar atividades conjuntamente neste processo de investigação e buscar compreender suas lógicas, percepções e visões de mundo, dentre outras atividades.

A pesquisa sobre a trajetória de Dona Maria da Silva foi baseada em narrativa desenvolvida a partir da utilização de recurso audiovisual e nas ferramentas metodológicas da Antropologia. 
Estimulada pela ideia de realização de produção de um vídeo sobre sua biografia, e suas atividades como parteira em município do arquipélago do Marajó, Dona Maria apresentou a si mesma em narrativa que envolve a oralidade, lembranças de diferentes momentos de sua vida e descrição de saberes sobre o partejar. Embora tenha iniciado essa prática e oficio no município de Breves, foi no município de Melgaço que desenvolveu suas habilidades e conhecimentos referentes ao apoio no momento em que outra vida nasce um outro ser.

As questões que nos motivaram a realização dessa investigação permitiram refletir sobre a relevância de uma mulher parteira em município do arquipélago do Marajó. Pela sua luta em prol da vida, pelo reconhecimento de sua importância no atendimento de mulheres grávidas, inclusive pelo próprio poder executivo municipal, consideramos que mesmo com as condições de subalternidade, essa é uma mulher que pode falar. Sua fala é considerada e respeitada, portanto, é ouvida.

Por certo, essa prática ancestral, e marcada pelo conhecimento para além da medicina oficial, não é um resquício do passado que permanece em tempos atuais, e nem se trata de algo que só é buscado diante da ausência de leitos, equipamentos ou profissionais de saúde nos hospitais. Trata-se de uma escolha, principalmente para as mães inexperientes e para aquelas que tem nas parteiras, ora representadas nesse estudo pela trajetória de Dona Maria, o apoio que lhes permite o protagonismo no momento do parto. Por certo, muitas são as mulheres que trazem consigo as lembranças dos conhecimentos ancestrais de outras mulheres nas situações relativas ao parto, às suas crias ainda recém-nascidas e aos cuidados consigo durante e após a gestação.

\section{Referências}

CANEN, Ana; XAVIER, Libânia Nacif. Multiculturalismo, memória e história da educação brasileira: Reflexões a partir do olhar de uma educadora alemã no Brasil imperial. In: MIGNOT, Ana Chrystina Venancio; BASTOS, Maria Helena Camara; CUNHA, Maria Teresa Santos (Org.) Refúgios do eu: Educação, história, escrita autobiográfica. Florianópolis: Mulheres, 2000. 63-80.

FLEISCHER, Soraya. Parteiras, buchudas e aperreios: uma etnografia do atendimento obstétrico não oficial em Melgaço, Pará. Belém: Editora Pakatatu/EDUNISC, 2011.

FREITAS, Sonia Maria de. História oral: possibilidades e procedimentos. São Paulo: Humanitas/Imprensa Oficial de São Paulo, 2002. 143 p.

HALBWACHS, Maurice. A memória coletiva. Trad. Beatriz Sidou. São Paulo: Centauro, 2003. 
JANNOTTI, Maria de Lourdes Mônaco; PAULA, Ricardo Zimbrão de. História oral: uma utopia? In: GARRIDO, J. del A. As fontes orais na pesquisa histórica: uma contribuição ao debate. Revista Brasileira de História. 25/26 - Memória, história, historiografia - Dossiê ensino de história. São Paulo: ANPUH, Marco Zero/ SCT/CNPq/FINEP, p. 9-14, 1998.

PEDRO, Maria Joana. As representações do corpo feminino nas práticas contraceptivas, abortivas e no infanticídio - Século XX. In: MATOS, Maria Izilda; SOIHET, Rachel (Org.) O corpo feminino em debate. São Paulo: Editora Unesp, 2003. p. 157-176

RIBEIRO, José da Silva. Antropologia visual, práticas antigas e novas perspectivas de investigação. Revista de Antropologia, São Paulo, USP, v. 48 n. 2, 2005.

SPIVAK, Gayatri Chakravory. Pode o Subalterno Falar? Belo Horizonte: UFMG, 2010.

WALSH, Catherine. Interculturalidade Crítica e Pedagogia Decolonial: In-surgir, re-existir e reviver. CANDAU, Vera Maria (Org.) Educação Intercultural na América Latina: entre concepções, tensões e proposta. Rio de Janeiro: Sete Letras, 2009. p.12-43 
http://dx.doi.org/10.18542/rmi.v14i22.9643

\title{
APONTAMENTOS TEÓRICOS SOBRE AS PESQUISAS (AUTO)BIOGRÁFICAS E DE HISTÓRIAS DE VIDA E SUAS DIMENSÕES FORMATIVAS E EXPERIENCIAIS
}

\section{THEORETICAL NOTES ON (SELF) BIOGRAPHIC RESEARCHES AND LIFE STORIES AND THEIR FORMATIVE AND EXPERIENTIAL DIMENSIONS}

\author{
Caio Corrêa DEROSSI ${ }^{1}$ \\ Universidade Federal de Viçosa \\ Karen Laíssa Marcílio FERREIRA ${ }^{2}$ \\ Universidade Federal de Viçosa
}

\begin{abstract}
Resumo: O presente ensaio teórico busca refletir sobre alguns horizontes teórico-metodológicos das pesquisas (auto)biográficas no campo educacional, destacando as dimensões acerca das formações e das experiências. Para tanto, o texto discutirá a partir de uma visão crítica aos pressupostos biológicos e exatos da ciência moderna, a produção e a construção de conhecimentos a partir do entendimento das (auto)biografias e das histórias de vida. Em seguida, explicita-se as relações dessas teorias e metodologias de pesquisa com os conceitos de formação e de experiência, visando ao final, compreender outras perspectivas relacionadas aos caminhos e percursos da produção da pesquisa nas ciências humanas e na educação.
\end{abstract}

Palavras-chave: Pesquisa (Auto)Biográfica. Histórias de vida. Formação de Professores. Experiência.

\begin{abstract}
This theoretical essay seeks to reflect on some theoretical and methodological horizons of (auto) biographical research in the educational field, highlighting the dimensions about the formations and experiences. To this end, the text will discuss, from a critical view of the biological and exact assumptions of modern science, the production and construction of knowledge based on the understanding of (auto) biographies and life stories. In the following, the relationship between these theories and research methodologies with the concepts of formation and experience is made explicit, aiming at the end, to understand other perspectives related to the paths of research production in the humanities and education.
\end{abstract}

Keywords: Biographical (Auto) Research. Life stories. Teacher Training. Experience.

\footnotetext{
${ }^{1}$ Licenciado em História e Mestrando pelo Programa de Pós-Graduação em Educação, ambos da Universidade Federal de Viçosa (PPGE-UFV). E-mail: caio.derossi@ufv.br

${ }^{2}$ Licenciada em Pedagogia pela Faculdade da Serra/ MULTIVIX e Mestranda em Educação pelo Programa de PósGraduação em Educação da Universidade Federal de Viçosa (PPGE-UFV). E-mail: karenkaispa@gmail.com
} 


\section{Introdução}

É de longa data a influência metodológica das Ciências Naturais e Exatas na produção de conhecimento das Ciências Humanas e Sociais. Em função de preconizar aspectos considerados como experimentais, assentados em pressupostos da objetividade, da racionalidade e da lógica da exatidão fizeram com que os processos, os sujeitos e as diferentes formas de se refletir sobre o mundo fossem preteridas nas análises (RODRIGUES et al., 2016). Porém, Bueno (2002) retrata que tal influência, tomada outrora como uma inspiração e uma matriz para os debates epistemológicos, tornou-se tirânica, uma vez que, só se considerava como científicas as produções realizadas sob a égide dos pressupostos exatos e naturais. Nesse sentido, Rodrigues et al. (2016) remonta ao recorte do surgimento e da consolidação das Ciências Humanas e Sociais e as influências dos conhecimentos dos outros ramos de conhecimento já circulantes, para entender o processo de crise dos paradigmas. Ocorrida nas duas últimas décadas do século XX e que marca opiniões até os presentes dias, com outras cores teóricas, reivindicando outras formas de se produzir ciência e questionando estatutos de verdade, de neutralidade e de imparcialidade no triângulo composto entre pesquisador, sujeitos e objetos. Logo, foram críticas aos modos de se entender a produção científica e a teorias correntes no campo, como o Positivismo e o Estruturalismo.

Assim, Batista Neto e Santiago (2015) observam que nas décadas de 1920 e 1930 começam movimentos metodológicos em prol das (auto)biografias e das histórias de vida, nesse primeiro momento advindos da Escola de Chicago, como ficou conhecido o grupo de pesquisadores da Universidade de Chicago dos Estados Unidos, que ofereceram contribuições no sentido da produção científica às áreas de Sociologia, Antropologia, Psicologia Social e Comunicação. Cabe destacar que, pelos trabalhos de Souza (2006), Batista Neto e Santiago (2015) e Passegi e Souza (2017) as investigações a partir dos pressupostos das (auto)biografias, narrativas, memórias e depoimentos estão em franca expansão nos campos das humanidades.

\section{Pesquisas (auto)biográficas e de histórias de vida}

Sobre a discussão acerca da autonomia do método biográfico, Franco Ferraroti (1988) acenou para a necessidade de outras formas metodológicas ligadas à produção de conhecimentos nas Ciências Humanas e Sociais, que não se ativessem a um modelo quantitativo e racionalista, mas sim, que investigasse os sentidos e as atribuições dos fenômenos sociais produzidos pelo/para os sujeitos, considerados protagonistas desses processos. Portanto, as (auto)biografias, as histórias de vida, as 
narrativas se colocaram como uma opção para a produção e a explicação científica dos fenômenos sociais, preconizando as vozes dos indivíduos que exprimem uma dimensão coletiva do narrado, frente as perspectivas objetivas de se conceber o fazer ciência.

Quando enfocados os estudos no campo educacional que primeiro adotaram os sentidos das narrativas, histórias de vida e (auto)biografias, Pineau (2006) além de sua obra, indica as produções de Nóvoa, Josso e Dominicé, preconizando o contexto europeu. Pineau indica que o seu livro lançado em 1983 que tratava da auto formação e da autobiografia, lançava as bases para as discussões acerca da formação e da profissionalização, a partir das trajetórias de vida e dos vieses de reconstrução das memórias. O autor ainda sugere uma periodização em três momentos distintos, de acordo com as produções na academia: o de eclosão nos anos 1980; o de fundação na década de 1990 e o de diferencial desenvolvimento nos anos 2000. Apesar de se ter críticas às formas de concepção das ciências ainda na década de 1970, Pineau (2006) marca os anos de 1980 como momento o qual as discussões acerca das biografias e narrativas emergem no cenário educacional, propondo refletir sobre outros espaços formativos, que não somente os formais, fazendo um contraponto às pesquisas quantitativas e entendendo tanto o professor quanto a educativa comprometidas com a transformação social. Esse quadro corroborou para que as pesquisas desenvolvidas no prisma educacional deixassem as perspectivas quantitativas e experimentais, ainda inspiradas nas teorias das tecnologias educacionais e da psicologia comportamentalista, que estavam em voga na década anterior. A década de 1980 ainda representou uma efervescência nas produções e eventos científicos e pela criação da Associação Internacional de Histórias de Vida e Formação que representou um esforço conjunto dos pesquisadores que partilhavam dos cotidianos, trajetórias, memórias e narrativas como objeto e entendimento teórico-metodológico de suas produções. Pineau (2006) entendeu que tais movimentações foram importantes para galgar o reconhecimento perante os pares da academia desses novos modos de se produzir conhecimentos. Nesse sentido, o autor afirma que:

Essas mudanças na pesquisa [...] impulsionou esse período de eclosão das histórias de vida em formação, como práticas multiformes de ensaio de construção de sentido por meio de fatos temporais vividos pessoalmente. Práticas existenciais de pesquisa-ação-formação, nas fronteiras das organizações, disciplinas científicas e técnicas do trabalho. [...] essa dinâmica de fundo utópico, porém vital, tomou inicialmente a forma de redes, depois de associações que, combinando encontros e produções, abriram os anos de 1990 como período de fundação. (PINEAU, 2006, p. 333-334)

Pineau (2006) observou que foi na década de 1990, período que denominou como de fundação dos métodos (auto)biográficos e das histórias de vida, uma vez que tiveram os primeiros trabalhos 
desenvolvidos nos Programas de Pós-Graduação em Educação com o respaldo e a utilização de tais abordagens. Nesse momento, fomentou-se e propiciou um cenário de maior envolvimento e contribuição de pesquisadores de diferentes instituições, em prol de socializar os conhecimentos e as investigações realizadas. Nóvoa (1995, p. 9) sobre o momento de expansão das produções que se afiliavam as abordagens biográficas e de história de vida, retrata que:

Em 1988, quando publiquei a obra O método autobiográfico e a formação, as abordagens biográficas eram pouco conhecidas em Portugal e a sua utilização na formação de professores não tinha qualquer significado. Em 1992, quando da primeira edição de Vidas de professores, a situação já tinha mudado consideravelmente[...]. Hoje, em 1995, o aviso deve ser escrito com letras ainda mais cheias.

Sobre a expansão mencionada por Nóvoa, podemos apontar que no contexto brasileiro, a criação do Grupo de Pesquisa em Docência, Memória e Gênero em 1994 na Universidade de São Paulo foi relevante, já que segundo Bueno et al. (2016), que era uma coordenadora do grupo, podese estudar as perspectivas trazidas por Pineau, Josso e Dominicé e refletir sobre o método biográfico enquanto um dispositivo formativo e um instrumento para as investigações. Os avanços em termos de produção são crescentes pelos anos 2000, em uma linha de continuidade de orientações pela temática, nos âmbitos das dissertações e teses, como Souza (2006) apresenta. Cabe destacar também a criação do Congresso Internacional de Pesquisa (Auto)Biográfica (CIPA), que é realizado no Brasil a cada dois anos, desde 2004 e fomenta a produção e o encontro das pesquisas e dos pesquisadores. Medeiros e Aguiar (2018) apontam para a existência de várias formas de se denominar as pesquisas educacionais que retrata a abordagem biográfica. Assim, encontram-se trabalhos que nomeiam como (auto) biografias, narrativas de formação, trajetórias escolares, histórias de vida, depoimentos escritos e orais, memórias e textos memorialísticos sobre os objetivos e metodologias que encaram temas acerca das experiências educativas dos sujeitos estudados.

Assim, a partir de trabalhos como de Bueno (2002), Souza (2006), Pineau (2006), Josso (2010) e Passegi e Souza (2017), dentre uma série de outras produções que poderiam ser citadas, reflete-se sobre as especificidades envolvidas entre as biografias e as (auto)biografias. A primeira retrata a narrativa da história por um mediador, não o próprio sujeito. Essa biografia é considerada a partir de um espectro que considera marcas da construção coletiva e dos aspectos do tempo cingidos nos sujeitos. Já a segunda, parte de uma perspectiva de protagonismo do indivíduo que conta suas histórias e tem no pesquisador, um participante, um pesquisado. Entretanto, Souza (2006) e Josso (2010) enfocam as (auto)biografias como dispositivos de formação e não o pesquisador enquanto um sujeito da investigação. Bueno (2002) atribui as características de dispositivo de formação e de instrumentos 
de investigação como uma particularidade do uso dessa metodologia no cenário educacional, já que, em outros campos observa-se o predomínio do segundo modo nas investigações.

Em relação as histórias de vida, Souza (2006) conceitua como uma narração situada em um contexto temporal que se constitui em uma tentativa de reconstrução e ressignificação das memórias e das próprias experiências. As histórias de vida são entendidas a partir da inserção dos sujeitos em contextos históricos, sociais e políticos, sendo esses estratos das dimensões pessoal e global que constituem a fertilidade da abordagem. Logo, Josso (2010) entende que as narrativas confluem os elementos de formação e das experiências para a própria constituição das identidades e de seus espaços formativos.

\section{Dimensões formativas e experienciais nas pesquisas (auto)biográficas e de histórias de vida}

“O que passa é, com efeito, o presente" (RICOEUR, 2010).

“A formação é feita da presença de outrem” (DOMINICÉ, 2010a).

Os conceitos de formação e de experiência merecem um detalhamento teórico quando tratamos das pesquisas que se filiam à abordagem (auto)biográfica. Assim, parte-se de Larrosa (2015) entendendo os sentidos das experiências mais aproximadas do campo pedagógico, reverberando assim, uma possível implicação com a formação, que será explicitada a seguir. Dominicé (2010a) aponta que o processo de formação se dá durante toda a vida, em um ritmo de descontinuidades e permanências, que ocorrem nos espaços e nos contextos que convivemos e partilhamos durante nossas trajetórias. Para o autor, são esses contextos particulares que compõem os cenários macroestruturais, que darão forma e significados aos contornos das histórias narradas. Assim, entendendo que os elementos e os contextos, em medidas e proporções singulares, formam as narrativas dos sujeitos, concorda-se com Larrosa (2015, p. 28) quando ele conceitua experiência como "aquilo que nos passa, ou que nos toca, ou que nos acontece, e, ao nos passar, nos forma e nos transforma". Logo, as experiências formativas se referem ao protagonismo e a agência protagonista da produção e da significação das trajetórias vividas.

Nesse sentido, apesar das experiências serem representadas a partir da subjetividade, das noções próprias do sujeito, elas se firmam de modo anterior na inserção e participação daquele indivíduo em um contexto social mais amplo. Por isso, as experiências dizem também de processos históricos os quais os narradores participaram. Seguindo essa perspectiva, Ferraroti (2010) ligou a 
experiência aos polos da subjetividade e de um contexto social direto que se fez parte. Assim, a experiência é expressa pelos entendimentos derivados da mediação humana entre o subjetivo e as realidades sociais. Logo, Larrosa (2015) entende que as experiências têm íntima relação com os sujeitos, pois ela perpassa por como são atribuídos os significados, as representações e os imaginários acerca de uma dada questão, bem como nos forma enquanto agentes dos processos sociais.

Desse modo, partindo dos desafios frente aos sujeitos entenderem as experiências enquanto elementos e processos formativos, a autora sugere as histórias de vida, enquanto uma forma de ilustrar e de explicitar como os próprios sujeitos tomaram e criaram caminhos e percursos diversos na vida e na dimensão profissional, a partir das experiências vividas. As narrativas das histórias de vida têm, além de aspectos retrospectivos, que recontam e reelaboram os fatos vividos, tem uma dimensão prospectiva que sugere desejos e planos futuros (DELORY-MOMBERGER, 2006). Assim, no processo oral ou escrito de narrar as histórias de vida, possibilitar ao próprio sujeito e ao interlocutor os sentidos das experiências vividas. Para Ricoeur (2010) as histórias de vida permitem que os outros conheçam o sujeito em questão. Entretanto, a biografia é marcada por diferentes versões e história, que demarcam um movimento para si e para o outro, podendo fazer o sujeito sumir ou aparecer na biografia. Logo, os atos de narrar-se ou contar-se de si ou de outros é marca ontológica da humanidade. Assim, Ricoeur (2010, p. 129) afirma que "contamos histórias porque, afinal, as vidas humanas precisam e merecem ser contadas".

Bolívar (2002, p. 5) que também denomina as histórias de vida como uma abordagem biográfico-narrativa, aponta que os interesses dessa metodologia "reconsidera o papel do investigador e a necessidade de incluir a subjetividade no processo de compreensão da realidade". O autor ainda sobre o método biográfico afirma que "a materialidade dinâmica do sujeito, suas dimensões pessoais (afetivas, emocionais, biográficas), que somente podem expressar-se por narrativas biográficas nas Ciências Sociais". Nóvoa e Finger (2010) também apontam que as pesquisas que seguem a abordagem (auto)biográfica podem aparecer com distintos nomes, mas ambos referindo-se à crítica ao positivismo e à falta de protagonismo dos sujeitos e dos seus entendimentos sobre a realidade. Assim, Ricoeur (2010) aponta que um dos saltos qualitativos das pesquisas se referem a própria dinâmica das histórias que são interligadas a outras narrativas, aos panos de fundos dos contextos que os indivíduos estão localizados. Nesse sentido, a linguagem é relevante para materializar as narrativas e apontar as formas pelas quais os sujeitos remontam e organizam as sequências do que é contado. Logo, as experiências não são acessadas de forma direta, mas sim, pelos arranjos e estruturas das linguagens. 
Nessa direção, Bolívar (2002) e Delory-Momberger (2006) entendem os fenômenos sociais como construções textuais que serão interpretados de formas distintas, a depender dos interlocutores. Assim, as pesquisas biográficas preocupam-se em entender as linhas de sentido das histórias atribuídas pelos sujeitos. Portanto, Dominicé (2010b) indica que a proposta (auto)biográfica se assenta em uma perspectiva imbricada entre os sujeitos e o pesquisador, já que ambas as narrativas, de quem fala e de quem escuta, se intercruzam em seus interesses e desejos. Tal intercruzamento, Bolívar (2002) entende como um duplo processo presente nas histórias dos sujeitos: uma que remonta ao contexto externo e outra às subjetividades, em constante cruzamento entre o particular e o global.

\section{A linha e o linho: tramas e tecidos metodológicos}

O presente artigo parte de uma perspectiva epistemológica construcionista, por entender como Esteban (2010) que a interação entre os seres humanos é tão genuína que não se deve partir como objetivo da pesquisa revelar ou descortinar uma verdade absoluta preexistente em determinado contexto. Logo, a construção do conhecimento é entendida aqui como um processo que envolve compreensão das experiências vividas e criação de significados sociais, conjugadas em um prisma relacional entre o coletivo e o subjetivo. Nessa mesma direção, concorda-se também com Esteban (2010), que por ser uma pesquisa que reflete as ações e significações humanas, deve ser então compreensiva, dinâmica e holística, para organizar e considerar os aspectos individuais com suas relações globais. Assim, Esteban (2010, p. 61) ressalta que: “As práticas de ensino, sendo práticas humanas, não podem ser abarcadas por explicações causais como as utilizadas para explicar fenômenos naturais, mas apenas podem ser entendidas à luz dos fins e das razões que as impulsionam [...]". Portanto, a pesquisa volta-se para se refletir sobre os sujeitos sociais, suas relações subjetivas, seus contextos, suas contradições e as representações imaginadas e atribuídas pelos sujeitos. Logo, a produção da pesquisa almeja seguir as motivações de Vieira Pinto (1969) no sentido de se comprometer com a proposição de horizontes para a intervenção, um pensamento autônomo e fomentar perspectivas que contribuam com o social e a sua possível transformação.

A pesquisa qualitativa tem como interesses as interpretações e os significados oferecidos pelos sujeitos e não os dados numéricos, quantitativos. Assim, entende-se como Chizzotti (2010) que a pesquisa qualitativa representa a vontade de buscar outros caminhos hermenêuticos, sem se desvincular dos arsenais teórico-metodológicos. Nesse tipo de investigação, algumas marcas são comuns e serão retratadas a seguir. É de relevo refletir sobre os contextos, as inserções e os ambientes partilhados pelos sujeitos da pesquisa, pois a partir de tais incursões, pode-se mobilizar algumas 
explicações e linhas de força para o entendimento de possíveis configurações subjetivas, ditos e não ditos durante as histórias contadas. Além disso, os contextos apontam para uma maior definição e especificidade das implicações dos sujeitos, dos fenômenos e dos desdobramentos sociais que podem se intercruzar. Logo, para Richardson (2009, p. 80):

[...] as investigações que se voltam para uma análise qualitativa têm como objeto situações complexas e estritamente particulares. Os estudos que empregam uma metodologia qualitativa podem descrever a complexidade de um determinado problema, analisar a interação de certas variáveis, compreender e classificar processos dinâmicos vividos por grupos sociais, contribuir no processo de mudança de determinado grupo e, possibilitar, em maior nível de profundidade, o entendimento das particularidades do comportamento dos indivíduos.

Desse modo, por pensar as narrativas dos professores supervisores, buscar compreender os processos de reflexão a partir das histórias, pensando nos processos de aprendizagem da docência e considerando o contexto dinâmico, complexo e tomado de teias e conexões que são marcas da profissão docente, a perspectiva de investigação qualitativa é adequada com as proposições. Outra característica dessa abordagem, citada por Esteban (2010) refere-se a possibilidade de se entender sobre as descontinuidades e permanências na formação e no desenvolvimento do sujeito, a partir da realidade produzida por/com ele. Assim, as práticas educativas e os diálogos entre/sobre os educadores são objetos de análise que oportunizam a reflexão sobre o ser docente e suas atividades profissionais. Em síntese, Taylor e Bogdan (1987) destacam que as pesquisas qualitativas demandam sensibilidade dos pesquisadores para os contextos, os detalhes, as entrelinhas oferecidas pelos participantes; uma visão ampliada dos sujeitos, dos contextos e dos fenômenos, buscando entender e valorizar tais categorias em suas especificidades e em relação. Destarte, a abordagem qualitativa celebra de forma mais coerente as subjetividades e os seus contornos interpretativos e relacionais.

Os métodos e seu conjunto, a metodologia, podem ser analogamente percebidas como os caminhos, os itinerários percorridos para se lograr a um destino imaginado. Como na vida, em função do tamanho da viagem, do transporte utilizado, das estradas, dos sertões e das veredas que compõem a paisagem, bem como a outros tantos fatores, outros horizontes, outras rotas, outros sujeitos e outros lugares podem aparecer na viagem, mudando o destino ou trazendo novidade ao que já se esperara. Partindo de um desejo e de uma vontade que nos prevalece para orientar a viagem, escolhe-se o das narrativas (auto)biográficas pelos elementos que aproximam os integrantes da investigação, possibilitando a reflexão e a possível aprendizagem nas reelaborações das histórias contadas. (FERRAROTI, 1988). 
Tanto para Passegi, Abrahão e Delory-Momberger (2012) as narrativas ganham força nos anos de 1980 com a crítica às formas de fazer e entender ciência, que na época, em específico as Ciências Humanas, estavam regidas pelos paradigmas das teorias estruturalistas, como o marxismo e a psicologia comportamentalista. Logo, emergem perspectivas, entre elas as narrativas, que reivindicaram os sujeitos em suas distintas dimensões, com suas agências e relações sociais, antes não observadas. Desse modo, as narrativas foram entendidas como formas de se refletir a partir das experiências, as (auto)formações, aprendizagens, implicações dos contextos históricos e como a profissão docente, nesse caso, foi praticada ao longo do tempo. Com a maior difusão, melhorias no acesso e na busca intensa pelos acontecimentos que muitas das vezes são repassados de formas excessiva e instantânea, curta, corroboram com a superficialidade dos fatos e com uma postura antinarrativa, contrária ao que Benjamin (1994, p. 203) trata como modo "artesanal de comunicação". Para o autor, a narrativa (auto)biográfica é fértil por possibilitar entender histórias as quais o sujeito participa em conjunto e que demonstram um entendimento de si e para si. Assim, Benjamin (1994, p. 203) afirma que:

Se a arte da narrativa é hoje rara, a difusão da informação é decisivamente responsável por esse declínio. Cada manhã recebemos notícias de todo o mundo. E, no entanto, somos pobres de notícias surpreendentes. A razão é que os fatos já chegam acompanhados de explicações.

Concordando com o autor, entende-se que o fazer narrativo representa uma resistência e direciona-se na contramão da dinâmica social atual, convidando os sujeitos a narrarem suas histórias sem imposições e aos interlocutores uma necessidade de disposição para que os fenômenos narrados possam ser sentidos, entendidos de forma profunda e não ao rés do interesse dado. Assim, Dewey (2007) observa que a predileção pela interpretação posta é resultado da vontade de não se envolver em atividades que demandam ou geram a reflexão. Nesse sentido, ocorre um afastamento pela escolha das narrativas, pois elas a partir das investigações podem gerar aprendizados e novos conhecimentos aos sujeitos.

Bolívar (2012) afirma que o modelo biográfico-narrativo se constitui como uma via nova e legítima para a construção de conhecimentos e reflexões sobre a formação em contextos postos. Nessa mesma perspectiva, Brito (2010, p. 64) entende então que:

[...] no âmbito da pesquisa qualitativa em educação, compõem fontes preciosas de produção de dados, cujo diferencial é protagonizar a vivência da escrita como alternativa para a reconstrução dos percursos do sujeito, seja na formação profissional, seja no cotidiano das práticas pedagógicas. Escrever sobre os processos formativos, 
sobre a ação docente desenvolvida e sobre o ser professor provoca a autorreflexão e o reencontro do sujeito com seus percursos de vida pessoal e profissional.

Dessa maneira, a narrativa é uma forma de reelaborar as histórias de vida em suas passagens e em seus processos de formação. Assim, entra em cena uma série de aspectos subjetivos de todos os sujeitos envolvidos, podendo se depreender os aspectos pessoais e profissionais das narrativas de formação trabalhadas por Souza (2007). Logo, concorda-se com Benjamin (1994) no ponto em que o narrador conta, descreve, vive e incorpora a sua realidade as dimensões das experiências sentidas por ele e ouvida de outros. Assim, quem narra pode entender de modo retrospectivo ou prospectivo suas práticas, suas histórias e as realidades que participaram e ajudaram a construir. Então, as narrativas dos professores supervisores refletem sobre as suas experiências, seus locais de formação e suas aprendizagens.

\section{Considerações finais}

As narrativas (auto)biográficas e de histórias de vida propiciam refletir sobre os acontecimentos e as experiências dos sujeitos, por apresentarem trajetórias individuais que revelam distintas dimensões do tempo, do espaço, das aprendizagens e dos processos subjetivos construídos em meio à coletividade. Então, urge um sentido de se pensar nos sujeitos das narrativas pensando em suas experiências e nos processos de aprendizagem. Assim, Josso (2010) aponta que a abordagem biográfica se propõe refletir sobre a totalidade das histórias de vida dos sujeitos, a partir de um eixo temático específico. Dessa forma, os elementos da aprendizagem e da formação são fundamentais para refletir os saberes e os fazeres dos sujeitos. Entendendo as narrativas como uma fonte, objeto de pesquisa e como um instrumento de formação de professore, em função das histórias e reflexões, Josso (2010) pensa que as narrativas possuem uma dimensão experiencial formadora, uma vez que elas aglutinam componentes das trajetórias pessoais com outros conhecimentos, possibilitando promover ações e ressiginificar saberes já constituídos, em prol da atuação profissional. Assim, a experiência formadora reúne os recortes, as escolhas pessoais dos sujeitos somados com as trajetórias de aprendizado, da carreira e das histórias de vida. Portanto, trata-se de se perceber um movimento de significação entre o que fora internalizado e os acontecimentos e dimensões externas ao sujeito. Um articulação entre representações objetivas e as sensibilidades dos sujeitos.

As narrativas, através dos relatos familiares, dos contextos de formação, das escolhas, da dinâmica própria da vida, da relação com o trabalho, além de nos oferecer relações para o pensar 
sobre as aprendizagens individuais, coletivas, nos propõe a pensar nas identidades e nas faces que revelamos, mostrando o que sentimos e como expressamos, as nossas produções e relações com a profissão docente e como sistematizamos e organizamos tudo isso. Assim, Josso (2010) trata do conceito de recordações-referências, para pensar nas memórias, lembranças e sentimentos que são evocados nas narrativas acerca dos processos de aprendizagem e das histórias de vida. Logo, segundo a autora, as recordações revelam tanto dimensões visíveis, físicas, quanto invisíveis, simbólicas, imiscuindo sentimentos e representações da sociedade. As narrativas unem os sujeitos aos exercícios de contar e de lembrar, as suas experiências, as suas dimensões afetivas ou não, que nos encaminham às recordações-referências.

Josso (2010) entende que as narrativas pessoais, sobre os processos de formação e de trabalhos, além de retratarem as dimensões de aprendizagem e das transformações ocorridas com os sujeitos ao longo de sua trajetória, bem como do reconhecimento dos conhecimentos e dos saberes que foram basilares para a aprendizagem e atuação profissional. Por isso, a autora entende que o conceito de experiência formadora ainda está em aberto, pois se revela nas capacidades e nos interesses dos sujeitos em narrar sobre si e propor relações sobre o vivido. Assim, quando entende-se a dimensão experiencial da abordagem biográfica, usam-se as narrativas como meio de análise potente das aprendizagens, individuais e coletivas, ocorridas ao longo da vida.

Destarte, Larrosa (2015) vai afirmar que para ser feita a auto narração, é necessário que o sujeito pense nos conteúdos e nas valorações feitas por si sobre si mesmo, nesse processo de rememorar e passar a vida a limpo. A auto narrativa apesar de se ter uma sistematização que pode parecer cronológica e contínua, é fruto dos processos de mudança, tomadas de consciência e de imaginários formulados sobre si e sobre os outros. Assim, abre-se margem para pensar nas práticas e concepções pedagógicas e os sentidos atribuídos à formação.

\section{Referências}

BATISTA NETO, J.; SANTIAGO, E. A abordagem biográfica, instrumento da pesquisa educacional e da formação docente: contribuições da Escola de Chicago e do Interacionismo Simbólico. Revista Cocar, Belém, v.9, n.17, p. 11-26, jan./jun. 2015.

BENJAMIN, W. Magia e técnica, arte e política: ensaios sobre literatura e história da cultura. 7. ed. São Paulo: Brasiliense, 1994.

BOLIVAR, A. Dimensiones epistemológicas y metodológicas de la investigación (auto) biográfica. In: PASSEGI, M. da C.; ABRAHÃO, M. H. M. B. (Org.). Dimensões epistemológicas e metodológicas da pesquisa (auto)biográfica: Tomo I. Natal: EDUFRN; Porto Alegre: EDIPUCRS; Salvador: EDUNEB, 2012. Coleção Pesquisa (Auto)Biográfica: temas transversais. p. 27-69. 
. “De nobis ipsis silemus?”: Epistemología de la investigación biográficonarrativa en educación. Revista Electrónica de Investigación Educativa, v.1, n. 4, p. 41-62, 2002.

BRITO, A. E. Narrativa escrita na interface com a pesquisa e a formação de professores. In: MORAES, D. Z.; LUGLI, R. S. G. (Org.). Docência, pesquisa e aprendizagem: (auto) biografias como espaços de formação/investigação. São Paulo: Cultura Acadêmica, 2010. p.53-67.

BUENO, B. et al. A atuação do Grupo de Pesquisa Docência, Memória e Gênero (1994 - 2006). In: SOUZA, E. C. (Org.). Autobiografias, histórias de vida e formação: pesquisa e ensino. Porto Alegre: EDIPUCRS, 2016, p. 18-29.

. O método autobiográfico e os estudos com histórias de vida de professores: a questão da subjetividade. Educação e Pesquisa, São Paulo, v. 28, n.01, p. 1-20, 2002.

CHIZZOTTI, A. Pesquisa qualitativa em ciências humanas e sociais. 3. ed. Petrópolis, RJ: Vozes, 2010.

DELORY-MOMBERGER, C. Formação e socialização: os ateliês biográficos de projeto. Educação e Pesquisa, v. 32, n. 2, p. 359-371, 2006.

DEWEY, J. Democracia e educação: capítulos essenciais. Apresentação e comentários Marcus Vinicius da Cunha. São Paulo: Ática, 2007.

DOMINICÉ, P. O processo de formação e alguns dos seus componentes relacionais. In: NÓVOA, A.; FINGER, M. (org.) O método (auto)biográfico e a formação. São Paulo: Paulus, 2010a. p. 143154.

. A biografia educativa: instrumento de investigação para a educação de adultos. In: NÓVOA, A.; FINGER, M. (org.) O método (auto)biográfico e a formação. São Paulo: Paulus, 2010b. p. 189-222.

ESTEBAN, M. P. S. Pesquisa qualitativa em educação: fundamentos e tradições. Porto Alegre: AMGH, 2010.

FERRAROTI, F. Sobre a autonomia do método biográfico. In: NÓVOA, A.; FINGER (org.). O método (auto)biográfico e a formação. São Paulo: Paulus, 2010. p. 31-58.

JOSSO, M. C. Experiências de vida e formação. 2.ed. São Paulo: Paulus, 2010.

LARROSA, J. Tremores: escritos sobre experiência. Belo Horizonte: Autêntica, 2015.

MEDEIROS, E. A. de; AGUIAR, A. L. de O. O método (auto) biográfico e de histórias de vida: reflexões teórico-metodológicas a partir da pesquisa em educação. Revista Tempos e Espaços em Educação, São Cristóvão, Sergipe, Brasil, v. 11, n. 27, p. 149-166, out./dez. 2018.

NÓVOA, A.; FINGER, M. O método (auto)biográfico e a formação. Lisboa: Ministério da Saúde, 1988.

NÓVOA, A. (org.). Vida de Professores. 2.ed. Porto: Porto Editora, 1995. 
PASSEGGI, M. da C.; SOUZA, E. C. de. O Movimento (Auto) Biográfico no Brasil: esboço de suas configurações no Campo Educacional. Investigación Cualitativa, Madri, v.2, n.1, p. 06-26, 2017.

PASSEGI, M. da C.; ABRAHÃO, M. H. M. B.; DELORY-MOMBERGER, C. Reabrir o passado, inventar o devir: a inenarrável condição biográfica do ser. In: PASSEGI, M. da C.; ABRAHÃO, M.

H. M. B. (Org.). Dimensões epistemológicas e metodológicas da pesquisa (auto)biográfica: Tomo II. Natal: EDUFRN; Porto Alegre: EDIPUCRS; Salvador: EDUNEB, 2012. Coleção Pesquisa (Auto)Biográfica: temas transversais. p. 29-57.

PINEAU, G. As histórias de vida em formação: gênese de uma corrente de pesquisa-ação-formação existencial. Educação e Pesquisa, São Paulo, v.32, n.2, p. 329-343, maio/ago. 2006.

RICHARDSON, R. J. Pesquisa social: métodos e técnicas. 3. ed. 9 reimpr. São Paulo: Atlas, 2009.

RICOEUR, P. Tempo e narrativa. São Paulo: Editora WMF Martins Fontes, 2010, t. 1.

RODRIGUES, C. S. D.; et al. Pesquisa em educação e bricolagem científica: rigor, multirreferencialidade e interdisciplinaridade. Cadernos de Pesquisa, São Paulo, v.46, n.162, p. 966982, out./dez. 2016.

SOUZA, A. V. M. de. Marcas de diferença: subjetividade e devir na formação de professores. Rio de Janeiro: E-papers, 2007.

SOUZA, E. C. de. A arte de contar e trocar experiências: reflexões teórico-metodológicas sobre história de vida em formação. Educação em Questão, Natal, v.25, n.11, p. 22-39, jan./abr. 2006.

TAYLOR, S. J.; BOGDAN, R. Introducción a los métodos cualitativos de investigación. 1ed. Barcelona, Buenos Aires, México: Ediciones Paidos, 1987.

VIEIRA PINTO, Á. Ciência e existência: problemas filosóficos da pesquisa científica. Rio de Janeiro: Paz e Terra, 1969. 
http://dx.doi.org/10.18542/rmi.v14i22.9642

\title{
TERRITORIALIZAÇÃO DE POLÍTICAS PÚBLICAS: APONTAMENTOS SOBRE A COVID-19 E O CÓDIGO DE ENDEREÇAMENTO POSTAL NAS FAVELAS CARIOCAS
}

\section{TERRITORIALIZATION OF PUBLIC POLICIES: NOTES ABOUT COVID-19 AND THE POSTAL ADDRESS CODE IN RIO FAVELAS}

\author{
André Luiz da Silva LIMA ${ }^{1}$ \\ Casa de Oswaldo Cruz, COC/FIOCRUZ
}

\begin{abstract}
Resumo: Em tempos de crise humanitária, provocada pela Pandemia do novo coronavírus, debates sobre o uso inteligente dos recursos públicos ocupam os tabloides com a opinião dos especialistas. No conjunto da sociedade brasileira, a fratura da desigualdade social ficou ainda mais exposta, e com isso a discussão em torno de políticas públicas e o papel do Estado diante do delicado momento ganhou espaço na esfera pública. Nesta direção, cabe referenciar a existência de contingentes populacionais significativos vivendo em localidades que não possuem o acesso adequado a serviços públicos básicos, que não gozam do direito à Cidade, e que são sistematicamente invisibilizados, inclusive no plano da estatística pública. São localidades sem CEP (Código de Endereçamento Postal), importantes não apenas para o serviço essencial de recebimento de cartas e encomendas pelos Correios, mas para atribuição de endereço aos indivíduos em contato com as malhas do Estado. Não ter endereço com CEP, por logradouro, significa ter a existência -espacialmente falando atrelada a outro lugar que não é onde se vive, e por consequência, com danos ao exercício da cidadania plena. $O$ enfrentamento ao Covid-19 depreende uma ação do Poder Público de forma eficaz, de políticas públicas articuladas, devidamente financiadas, transparentes $e$, não menos importante, territorializadas.
\end{abstract}

Palavras Chave: Favelas. Covid-19. Políticas Públicas

\begin{abstract}
In times of humanitarian crisis, caused by the new coronavirus Pandemic, debates about the intelligent use of public resources occupy the tabloids with the opinion of experts. In Brazilian society as a whole, the fracture of social inequality was even more exposed, and with this the discussion around public policies and the role of the State in the face of this delicate moment has gained space in the public sphere. In this sense, it is worth mentioning the existence of significant population contingents living in locations that do not have adequate access to basic public services, that do not enjoy the right to the City, and that are systematically made invisible, including in terms of public statistics. They are locations without CEP (Postal Address Code), important not only for the essential service of receiving letters and parcels by the Post Office, but for assigning addresses to individuals in contact with the state's networks. Not having a postal address, by street address, means having one's existence - spatially speaking - linked to another place that is not where one lives, and consequently, with damage to the exercise of full citizenship. The confrontation with Covid-19 implies an effective government action, articulated public policies, duly financed, transparent and, not least, territorialized.
\end{abstract}

Keywords: Favelas. Covid-19. Public policy

\footnotetext{
${ }^{1}$ Graduado (Bacharelado e Licenciatura) em História pela UFRJ (2009), Mestre (2012) e Doutor (2017) em História das Ciências e da Saúde pelo PPGHCS/COC/Fiocruz. E-mail: andrelimapesquisa@ gmail.com
} 


\section{Introdução}

De um lado, temos a Empresa Brasileira de Correios e Telégrafos (EBCT) que possui a responsabilidade, na ação conjunta com as prefeituras, de prover o Código de Endereçamento Postal por logradouros, possibilitando assim não apenas nortear encomendas postais, mas subsidiar a montagem dos escopos de atuação de empresas privadas (logística, por exemplo) e intervenções do Poder Público. Do outro, um número significativo de brasileiros residindo em logradouros situados em territórios socioambientalmente vulnerabilizados, ou como certos documentos oficiais denominam, em assentamentos precários e/ou aglomerados subnormais ${ }^{2}$. No Rio de Janeiro, e em outros centros urbanos, estes assentamentos, populares, constituídos com a marca da autoconstrução das residências e da modelagem não oficial dos arruamentos, recebe há décadas a denominação de favelas (VALLADARES, 2005; FERNANDES e LIMA, 2014; LIMA, 2018). Estas localidades comumente não possuem regularidade fundiária formal, e por conseguinte, não são visíveis nos mapas, não possuem CEP's. Visto que as formas e arranjos de produção de vida nestas localidades, nas grandes cidades, a pandemia do novo coronavírus (Covid-19), que chegou ao Brasil no final de fevereiro, tem agravado e agudizado as vulnerabilidades de quem lá mora, algo que os movimentos sociais, pesquisadores e ativistas têm denunciado na Esfera Pública, em ditos e escritos. O enfrentamento desta grande crise humanitária perpassa por ações de pesquisa, assistência, vigilância, promoção e reabilitação, no campo da Saúde, de apoio às empresas, de suporte e apoio econômico-social às famílias de trabalhadores - que terão inúmeros desafios para o cumprimento do isolamento social - por parte do Estado. Para o gerenciamento desta crise, dentre outras ações, se coloca como de suma importância o acesso a dados fidedignos sobre as populações que residem nestas localidades para o planejamento e atuação eficaz, que salvará vidas. Neste sentido segue a problemática central deste texto, que se coloca em lançar luz sobre a inexatidão dos dados fundamentais para uma ação eficaz do Estado nas favelas cariocas, com foco nas inconsistências presentes nos Códigos de Endereçamento Postal.

Como ponto de reflexão ${ }^{3}$, será tomado como referência o conjunto de favelas que formam o que uma determinada literatura denomina como Complexo de Manguinhos. ${ }^{4}$ Cabe referenciar esta

\footnotetext{
${ }^{2}$ Ver Souza e Silva, 2011.

${ }^{3}$ Constatações visíveis em Manguinhos da inadequação do uso do CEP também têm sido relatados em conversas informais por líderes sociais de outras localidades empobrecidas da Cidade do Rio de Janeiro.

${ }^{4}$ Manguinhos é formalmente um bairro, situado na Zona Norte do Rio de Janeiro. A história de uso e ocupação do solo desta localidade possibilita a percepção da existência de diferentes sublocalidades, com histórias distintas, marcadas pela luta de seus moradores pela vida e pela experimentação recorrente de processos de vulnerabilização social, ambiental, econômico e político.
} 
reflexão emerge no âmbito de um projeto $^{5}$ em cooperação social, de pesquisa-ação, promovido pela Fundação Oswaldo Cruz (Fiocruz), que atua no apoio de arranjos locais de governança territorial, com vistas à construção permanente de estratégias de Advocacy para políticas públicas saudáveis e territorializadas.

\section{Direito à Cidade, Direito à Vida}

Se pensarmos o direito à cidade, na perspectiva analítica de Henri Lefebvre (1968), este se processa no acesso igualitário e equânime aos bens, serviços, estruturas e espaços públicos das cidades.

O direito à cidade significa então restaurar o sentido de cidade, instaurar a possibilidade do - bem viver para todos e fazer da cidade —o cenário de encontro para a construção da vida coletiva. $O$ direito à cidade é a possibilidade de construir uma cidade na qual se possa viver dignamente, reconhecer-se como parte dela e onde se possibilite a distribuição equitativa de diferentes tipos de recursos: trabalho, saúde, educação, moradia, além de recursos simbólicos tais como participação, acesso à informação, etc. (MATHIVET, 2010, p.21)

A “mão invisível” do mercado, postulado por Adam Smith (1983), ao contrário, tem sido "muito visível" na produção de cidades excludentes, que coloca diversos assentamentos humanos sob processos produtores de estigmas e vulnerabilizações.

[...] o uso e a ocupação dos espaços urbanos não se dão a contento, mostrando-nos que o direito à cidade, isto é, o direito de viver em condições propícias à habitação, não tem sido de todos e todas que constroem a cidade. Tem sido na verdade, um expoente de exclusão e de perpetuação de privilégios e desigualdades (ROLNIK , 2002, p.53)

No âmbito da história urbana da Cidade do Rio de Janeiro no século XX, especificamente com relação às favelas, o debate em muito se estruturou entre urbanizar ou remover. Neste sentido, o contexto político local (Regional e Nacional), os escopos assumidos para o desenvolvimento e as questões econômicas no nível nacional, os projetos de cooperação internacional em tempos da Guerra Fria, os aspectos de especulação imobiliária e as frentes de geração de riqueza econômica (indústria, comércio e serviços) demandando recursos humanos forjaram os cenários em que as favelas emergiram para atender uma necessidade humana básica, e de onde se inicia a experimentação da cidade para as classes populares, que é a habitação.

\footnotetext{
${ }^{5}$ Projeto Promoção de Territórios Saudáveis e Sustentáveis de Centros Urbanos, conduzido pela Coordenadoria de Cooperação Social da Presidência da Fiocruz, junto aos moradores do Complexo de Manguinhos.
} 
No processo de modelagem da urbes, tendo o Rio de Janeiro como parâmetro, emergiram zonas de exclusão, catalisadas pelas desigualdades sociais, ambientais, econômicas e políticas, cuja existência também atua na reprodução dessa desigualdade, bem delineada pela categoria 'Urbanismo de Risco', formulada por Raquel Rolnik (1999).

Urbanismo de risco é aquele marcado pela inseguridade, quer do terreno, quer da construção, ou ainda da condição jurídica da posse daquele território. As terras onde se desenvolvem estes mercados de moradia para os pobres são, normalmente, justamente aquelas que, pelas características ambientais, são as mais frágeis, perigosas e difíceis de ocupar com urbanização: encostas íngremes, beiras de córregos, áreas alagadiças. As construções raramente são estáveis, e a posse quase nunca totalmente inscrita nos registros de imóveis e cadastros das prefeituras. (ROLNIK, 1999, p.100)

O que chama atenção neste urbanismo é o risco das condições ambientais acentuado por outras vulnerabilidades, como a econômica, social e política. E neste sentido, os moradores das favelas, que por sua força de trabalho constrói e mantém o funcionamento da cidade capitalista, ao protagonizar a adoção de medidas para provimento de sua habitação, acaba por concentrar os inúmeros ônus desta empreitada.

O risco é, antes de mais nada, do morador: o barraco pode deslizar ou inundar com chuva, a drenagem e o esgoto podem se misturar nas baixadas -a saúde e a vida são assim ameaçadas. No cotidiano, são as horas perdidas no transporte, a incerteza quanto ao destino daquele lugar, o desconforto da casa e da rua. (ROLNIK , 1999, p.100)

Deste modo,

Em uma cidade dividida entre a porção legal, rica e com infra-estrutura e a ilegal, pobre e precária, a população que está em situação desfavorável acaba tendo muito pouco acesso a oportunidades de trabalho, cultura ou lazer. Simetricamente, as oportunidades de crescimento circulam nos meios daqueles que já vivem melhor, pois a sobreposição das diversas dimensões da exclusão incidindo sobre a mesma população fazem com que a permeabilidade entre as duas partes seja muito pequena. (ROLNIK, 2002, p.53)

Os estigmas e estereótipos atribuídos aos moradores de favela são os mais diversos, passando pela apatia política, pela desorganização comunitária, pela preguiça nata, ou ainda, por serem violentos e incivilizados. Entretanto, pesquisadores como Carlos Nelson Ferreira dos Santos (1981), Janice Perlman (1977) e Mário Sergio Brum (2011) demonstraram em seus estudos o quão incorreto é a leitura dos moradores de favelas a partir destes estereótipos estigmatizadores. Outro aspecto, reproduzido inclusive por órgãos oficiais, é o trato destes territórios como espaços homogêneos. As favelas estão 
localizadas em terrenos elevados ou planos, reunindo centenas, milhares ou dezenas de milhares de moradores, com diferentes equipamentos, serviços e mobiliários urbanos, sendo constituída por casas e/ou apartamentos, com diferentes níveis de violência e presença do poder público, além das variadas características ambientais, as favelas constituem-se como territórios com paisagens razoavelmente diversificadas. (SOUZA e SILVA, 2011, p. 5)

Nesta relação de produção de vida e direito a Cidade, existe um componente importante de direito à vida que se conecta fortemente com o direito à uma vida saudável. A Saúde Pública e o Urbanismo, enquanto áreas de conhecimento, possuem diversos momentos intercambiáveis no desenrolar de suas histórias. Inclusive subsidiando muitas reformas e projetos da urbe, muitas destas marcadas por arranjos que buscavam eliminar - ou afastar dos olhos - os indesejáveis: negros, pobres, imigrantes, homossexuais etc.

Nos debates internacionais recentes, especialmente a partir de 1970, com o surgimento do conceito de Desenvolvimento Sustentável, tendo por marco histórico de origem a realização da Primeira Conferência das Nações Unidas sobre o Meio Ambiente e Desenvolvimento (1972), das Conferências de Alma Ata(1978) e Ottawa (1986), da criação do Programa das Nações Unidas para os Assentamentos Humanos (1978), e num recorte mais contemporâneo, em 2015, da Agenda ONU 2030, a questão da Saúde, em seu conceito ampliado, ressignificaria os sentidos do morar e viver na urbe de maneira saudável.

Indubitavelmente o debate da ampliação e ressignificação do processo saúde-doença, com a incorporação dos determinantes sociais na equação vigente, tem influências advindas dos estudos e reflexões em torno da Medicina Social Latino-Americana, na qual as experiências em saúde pública Chilena e Cubana não podem ser esquecidas (Iriart et al., 2002). Também importante sinalizar a contribuição do Movimento Sanitário Brasileiro que criou as condições de possibilidade para a emergência da Saúde Coletiva enquanto campo de conhecimento de saberes e práticas e da emergência do Sistema Único de Saúde no Brasil (LUZ, 2009; NUNES, 2016).

No Brasil, a VIII Conferência Nacional de Saúde trouxe esse conceito ampliado no cerne dos seus debates, na qual seus artífices influenciaram os tomadores de decisão presentes na esfera pública de modo que na Carta Constitucional de 1988 incorporasse a criação do Sistema Único de Saúde, regulamentado por Leis e outros diplomas legais constituídos nos anos seguintes (ESCOREL, 1999; PAIVA e TEIXEIRA, 2014). A ideia de direitos que permeava a Carta Constitucional, certamente influenciada por um momento pós-regime de exceção, catalisou os anseios de uma população que vivia num momento sensível da história nacional com amplo desemprego, inflação galopante, notícias 
de corrupção (antes ofuscadas pelo regime), onde os serviços públicos de saúde e educação, por exemplo, não possuíam alcance universal, constituindo assim bolsões de excluídos por todo o país.

Aparentemente o período pós-1988 inauguraria uma época em que os projetos para as favelas baseados na remoção e extermínio das mesmas seriam colocados de lado. A tensão social causada pelo aumento do desemprego e da elevação da precariedade das condições de vida, especialmente a partir da década de 1980, passaram a ocupar espaços nos debates sobre a Cidade e sua governança. Afinal, naquele momento, cada favelado teria o direito ao voto, e com isso, o redesenho das relações entre políticos como representantes do Estado e essa população passariam por diversos rearranjos até a presente data. Esse processo deve ser lido a partir de uma série de eventos sócio-políticos e econômicos, que no Rio de Janeiro pode ser exemplificado no(a): I. surgimento de novos mediadores nas favelas: agentes comunitários, organismos internacionais, organizações não governamentais; II. enfraquecimento político das associações de moradores; III. ascensão das denominações religiosas de matriz neopentecostal com participação na esfera política; IV. reordenamento do negócio transnacional de venda de drogas (cocaína, por exemplo) e armas de fogo, e suas inserções nas favelas; V. novos arranjos de intervenção nestes espaços como o Favela-Bairro, Morar Carioca e o PAC-Favelas, por exemplo (ZALUAR, 1994; CARVALHO, 1995; SOUZA, 1996; PANDOLFI; GRYNSZPAN, 2002; ZALUAR, 2004; MACHADO DA SILVA, 2006; LIMA, 2017).

Em 2020, o conjunto dos projetos de urbanização pensados para as favelas, nos últimos 20 anos, podem ser agrupados pelas seguintes características: I. Baixa Participação Social; II. Relacionamento com os favelados, na maioria das vezes, mediados por relações de tutela e/ou clientelismo; III. Manutenção do racismo e de diversos estigmas; IV. Sub financiamento e descontinuidade, trazendo assim, em muitos casos, um cenário (econômico, ambiental, urbano e social) pior do que estava antes; V. Desarticulação com as políticas públicas e arranjos de financiamento para a sustentabilidade do empreendimento.

Uma nota à parte é o grande aparato policial orientado a agir nas favelas, com operações de alta letalidade, desrespeito aos direitos humanos e frequentes ilicitudes por parte dos agentes do Estado. A elevada mortalidade, tanto de policiais, como de moradores (sejam estes envolvidos ou não com o comércio varejo de substâncias entorpecentes ilícitas na lei), e o alto encarceramento, com baixo impacto na segurança dos moradores destes territórios, denota um fracasso recorrentemente denunciado por organismos internacionais e movimentos sociais pelos direitos humanos (RAMOS; MUSUMECIL, 2005; BARROS, 2008; LIMA et all, 2014). 


\section{A COVID-19 nas Favelas}

O momento atual, alvitra-se, será lembrado por ser aquele em que se instaura uma crise humanitária de amplitude mundial, disparada sem sombras de dúvidas pela Pandemia do COVID-19, mas catalisada pelas formas de se produzir e distribuir a riqueza e os benefícios dela advinda, na qual a concentração de renda, a desigualdade social crônica, o racismo estrutural, o patriarcado e o uso irracional dos recursos naturais compõem um cenário tenebroso.

No tocante ao processo de decisões do Poder Público, no Brasil, observa-se um descompasso entre as orientações oficiais do Ministério da Saúde e o Chefe do Poder Executivo, e entre as deliberações do Governo Federal e os governos Estaduais e Municipais. Cabe ainda relatar os discursos que invalidam a ciência e qualquer deliberação oficial advinda dela, exemplificado, por exemplo, no debate colocado na Esfera Pública sobre a necessidade de Isolamento Social, e o uso quase que místico de certos medicamentos como se fossem “pílulas mágicas”. Ademais, escritos dão conta de que uma das maiores ameaças existentes no processo de enfrentamento ao COVID-19 seja o Presidente da República Jair Messias Bolsonaro (RODRIGUES, 2020, LANCET, 2020, DISEASES, 2020).

Nos programas de televisão e nas Mídias Sociais, em meio à Pandemia, foi possível assistir aos protestos desencadeados em diversas cidades nos Estados Unidos da América (EUA), e na sequência em várias partes do Planeta, por conta do racismo ainda vigente na sociedade contemporânea. O estopim fora o assassinato do afro-americano George Floyd em 25 de maio de 2020, por policiais, num evidente ato de ilegalidade perversa. . No Brasil, ainda que com repercussões bem menores do que nos EUA, os atos antirracismo estiveram acompanhados de manifestações e ações da Sociedade Civil em defesa do Estado Democrático de Direito.

Cabe referenciar que os números de mortos por armas de fogo, especialmente daquelas recorrentes das operações policiais nas favelas do Rio de Janeiro, denotam - para alguns ativistas da sociedade civil organizada - um projeto silencioso de genocídio negro operado pelo Estado (ALMEIDA, 2014; VARGAS, 2010).

Percebe-se que os arranjos constituídos para enfrentamento do COVID-19 pelas diversas instâncias do Estado brasileiro têm em comum a desinformação, seja pela ausência destas, seja pela insuficiência de dados ou ainda, pela superprodução de dados apresentados de forma descontextualizada. Ademais, sobre as favelas e periferias, a presença do Estado atuante de forma pouco eficaz traz consigo um elemento histórico de desconhecimento de dados fundamentais das populações lá estabelecidas. No documento "Socioepidemiológico da Covd-19 nas favelas" 
produzido pela Fundação Oswaldo Cruz, uma fala de uma histórica liderança dos movimentos sociais em favelas, Itamar Silva, reflete essa preocupação: “Eu fico sempre impressionado que já temos 125 anos de favelas e a gente vive o drama de origem: Quantos somos? Onde estamos? É impressionante [...]." (FIOCRUZ, 2020).

Reitera-se, portanto, um dos aspectos relevantes deste texto que é referenciar a produção sistemática da não-informação sobre determinados grupos populacionais, produzindo mecanismos sofisticados de produção de invisibilidade. Deste modo, o contexto da supressão de direitos que vigora nas favelas e os processos de vulnerabilização, atenuados pela Covid-19, por diversas razões não ocupam a agenda política nacional. Entretanto, a busca por argumentos em defesa de políticas promotoras da vida para esta população, esbarra, dentre outros entraves, na inexistência de dados e informações fidedignas.

\section{Políticas Públicas Territorializadas, CEP e Covid-19}

Nas favelas, periferias, bairros populares, cidades dormitórios, comunidades empobrecidas, o cenário socioeconômico de milhões de pessoas pobres, sem emprego - ou em trabalhos precarizados - fora exposto na esfera pública. A atual Pandemia funcionou como uma espécie de catalisador, ampliando as vulnerabilidades e aumentando o risco de morte às pessoas que nestas localidades residem. Tal cenário demanda uma atuação inter/multisetorial por parte do Poder Público, em especial dos setores de Saúde, Conservação Municipal, Assistência Social e Educação. Para tal, informações sobre as populações residentes nestas localidades, seja no campo epidemiológico, de vigilância ou com fins de planejamento se coloca como um detalhe que pode significar a vida ou morte de milhares de pessoas. Neste sentido,

não há números gerais, confiáveis, sobre a ocorrência de favelas ou loteamentos irregulares em todo Brasil. Por falhas metodológicas ou ainda por uma dificuldade óbvia de conhecer a titularidade da terra sobre as quais as favelas se instalam, o IBGE apresenta dados bastante subdimensionados. A busca de números mais rigorosos nos conduz a alguns diagnósticos elaborados por governos municipais, teses acadêmicas ou organismos estaduais que entretanto, fornecem dados localizados e restritos. (MARICATO,2000. p. 154)

Mas como planejar ações em contextos em que vigora a desinformação sobre os grupos populacionais? Como os governos poderão incidir sobre contextos de vulnerabilização sem dados fidedignos? Os dados, especialmente os detalhados e agrupados de forma georreferenciada, são uma importante ferramenta para os gestores (Domingues \& Simões, 2007). Afinal, existe um certo 
consenso na literatura de que uma "base de dados confiável e, em especial, integrada, confere segurança e eficácia à decisão para a orientação de políticas públicas” (SANNA, 2014, p. 2).

O dito popular "cobertor curto" ilustra bem o cenário enfrentando pelos gestores de políticas públicas, em especial, em contextos em que líderes do projeto político-econômico vigente advogam a austeridade como ponto essencial. A crise humanitária advinda da Pandemia causada pelo Covid19 eleva as dificuldades dos gestores públicos, especialmente aquelas advindas de problemas estruturantes e históricos.

No - já referenciado - boletim "Socioepidemiológico da Covd-19 nas favelas", produzido pela Fundação Oswaldo Cruz, temos o recorte temporal do mês de abril para a contabilização dos bairros com maior incidência de moradores acometidos pelo Covid-19, a saber: Bonsucesso, Gávea, Jacaré, Rocha e São Cristóvão. Os dados pesquisados pelos autores do referido documento foram obtidos junto à Secretaria Municipal de Saúde (Fiocruz, 2020). O que chama atenção, objeto deste paper, neste Boletim é o fato de que os bairros de Bonsucesso, Gávea, Jacaré, Rocha e São Cristóvão possuem regiões cujos logradouros estão ligados à delimitação oficial de bairro constituída pela Prefeitura da Cidade do Rio de Janeiro, e a referência do endereço à partir do Código de Endereçamento Postal não são coincidentes.

Em tempos de Covid-19, observou-se que nas rotinas de preenchimento dos prontuários dos usuários do SUS ou nos documentos que atestam os óbitos, uma referência contida em todos esses instrumentos é o campo do Código de Endereçamento Postal. Estes, por sua vez, não estão atualizados com a legislação que regulamenta a conformação/delimitação/espacialidade dos bairros e logradouros. Na região norte da cidade do Rio de Janeiro, o CEP 21040-361 identifica o endereço como sendo pertencente ao bairro "Manguinhos", mas refere-se a um conjunto de logradouros dentro de uma sublocalidade da Maré denominada Conjunto Esperança. O mesmo ocorre com o CEP 20911330, que aponta para o Conjunto Habitacional Samora Machel, bairro Benfica, que indubitavelmente se localiza dentro do Complexo de Manguinhos (Bairro Manguinhos, inclusive), seja pela política de saúde, segurança pública, educação ou assistência. Aliás, a referida localidade é dotada de logradouros, o que demandaria CEPs específicos. Para os Correios, este Conjunto Habitacional é uma "localidade não codificada por logradouros", o que explica a operação dos correios, mas não resolve a atribuição errônea como pertencente ao bairro Benfica de um local situado no bairro Manguinhos conforme leis Municipais que regulam o uso do solo.

Nas áreas em que a Estratégia Saúde da Família se faz presente, e o atendimento se inicia na Atenção Primária, tais distorções podem ser ajustadas nos prontuários. Mas nem sempre é possível, visto que os sistemas de prontuários eletrônicos não são unificados na cidade do Rio de Janeiro. 
Retomando, como exemplo, o bairro de Bonsucesso, que teve a maior incidência, entre os bairros da Cidade do Rio de Janeiro, de Covid-19 em abril de 2020. Bonsucesso tem sua delimitação espacial validada por diplomas legais da Prefeitura, e segue, no recorte espacial atribuído no CEP uma sobreposição sobre áreas de favelas, algumas destas já identificadas na legislação como bairros autônomos. Parte do Morro do Adeus, que pela legislação Municipal consta como integrante do Complexo do Alemão, tem sua referência pelo CEP como sendo situado em Bonsucesso. O mesmo se aplica com parte de um conjunto de logradouros situados, pela legislação urbanística municipal, no bairro Maré, mas que se identifica pelo CEP como se estivesse situado em Bonsucesso.

Em Manguinhos o caso desta relação de sobreposição espacial com Bonsucesso está na localidade conhecida como Vila São Pedro. Mas ali, existe uma convergência entre o CEP e os diplomas legais municipais sobre o uso do solo. Permanece, entretanto, uma divergência políticosimbólica, que apesar de estar situada em Bonsucesso, tal localidade tem suas relações de pertencimento vinculadas ao que se chama de Complexo de Manguinhos (Fernandes \& Costa, 2009). Essa delimitação ampliada de Manguinhos tem raízes na história dos movimentos de ocupação e uso do solo, no domínio territorial por parte de grupos armados em atividades ilegais, dentre outras questões não aprofundadas neste paper.

Trata-se de formalizar a presença das favelas nas bases cartográficas e nos códices de dados populacionais. Há anos os moradores das favelas, por meio dos seus próprios recursos, contornam esse problema a partir do uso do endereço de algum parente, amigo ou local de trabalho como meio para recepção de correspondências, ou ainda, apostando na centralidade da entrega de cartas na associação de moradores.

Se antes da Pandemia a eficácia e efetividade das políticas públicas nestes territórios já o eram questionáveis, no atual contexto, estas se tornaram - em muitas das vezes - a diferença entre a vida e a morte de milhares de pessoas. Um desafio aos governantes, especialmente no âmbito da municipalidade dos grandes centros urbanos brasileiros, se coloca em operar ações, projetos e programas juntos às favelas de forma articulada, inter/multisetorial, mitigando as vulnerabilidades e promovendo a saúde. Coloca-se então o desafio do estabelecimento de uma Governança que articule, no nível sub-municipal, as diversas ações. Infelizmente constata-se um vazio de informações sobre um contingente populacional significativo.

A Prefeitura da Cidade do Rio de Janeiro, dentre outras situadas em centros urbanos brasileiros, possui uma demanda gerencial de operar políticas públicas eficazes dentro de contextos nada favoráveis. Historicamente, o modo de se produzir e gerenciar o Estado brasileiro, em específico na Nova República, gerou e manteve elevada concentração de riqueza, severa desigualdade social, 
danos constantes ao ambiente, baixo capital social, fragmentação das políticas públicas, aparelhamento dos órgãos do Estado por grupos ideológicos, dentre outros problemas.

As favelas surgiram no desenrolar do século XIX, adquirindo uma visibilidade específica ${ }^{6}$ no século XX, constituindo-se como aglomerados populacionais predominantemente residenciais, cujo desenho urbanístico do uso do solo não seguiram os parâmetros oficiais. Estes aglomerados possibilitaram a constituição da cidade capitalista, seja na sua montagem e sustentação, não como algo à parte, mas como componente fundamental da existência da urbe, ou seja, favela é cidade.

As ações coletivas empreendidas por moradores de favelas remontam aos movimentos ocupacionais do solo em sua origem, cujas características depreende de um olhar histórico-geográfico destas. A regularização fundiária tem sido transversalmente um componente importante nas pautas destas ações coletivas, e neste sentido, dotar juridicamente as favelas de regularidade urbanísticofundiária, e por conseguinte, atribuir-lhes formalmente nome de ruas e logradouros, com seus respectivos Códigos de Endereçamento Postal se coloca como fundamental nesta agenda. No plano legislativo, identifica-se avanços normativos importantes, mas que demandam "vontade política" para que sejam implementados. Neste sentido,

novos instrumentos jurídicos previstos ultimamente pela legislação urbanística procuram reverter essa situação, consolidando, assim, uma regularização fundiária sustentável que permita tanto a legalização do solo nas favelas quanto a integração socioespacial dos seus habitantes. (GONÇALVES, 2009, p.248)

Se a regularização fundiária, e por conseguinte, atribuição de CEP se constituem como algo relevante na agenda urbana brasileira, uma dimensão significativa desta pauta se coloca na redefinição dos limites territoriais de cada bairro, e ajustes destas redefinições nas informações oficiais dos CEPs.

Tais ajustes contribuirão para o melhor planejamento das ações e políticas públicas, da transparência operacional do Estado junto à sociedade civil organizada, e no que tange ao seu monitoramento, conduzi-lo de forma eficaz, desmontando mitos e estereótipos. Aliás, tal processo contribui também para o desenvolvimento econômico, possibilitando aos empreendedores dados que poderão nortear suas iniciativas.

${ }^{6}$ Visibilidade essa com uma forte carga de estigmas, racismos e estereótipos. 


\section{Considerações finais}

No momento atual, por conta da crise humanitária mundial causada pelo novo coronavírus, cabe ao Estado brasileiro instituir ações em saúde (de assistência, vigilância, promoção e reabilitação) e fomentar/articular/conduzir projetos inter/multisetoriais no enfrentamento a Covid-19, demandando dados fidedignos sobre os territórios. As Organizações Não Governamentais, os Conselhos de Políticas Públicas, a Imprensa, e outros setores da sociedade civil, especialmente daqueles que atuam no Advocacy para políticas públicas territorializadas depreendem de dados sobre a população da cidade de forma georreferenciada, fidedigna e o mais atual possível.

O cenário de produção de dados oficiais sobre as populações residentes em favelas, especialmente no Rio de Janeiro (aqui exemplificado a partir de Manguinhos), não é dos mais otimistas. No desenvolvimento do argumento deste paper, salientou-se que os estigmas e processos de vulnerabilização produzidos socialmente denotam um projeto oficioso de silenciamento e invisibilidade destes grupos populacionais.

O ponto de argumentação, aqui enunciado, partiu de um aspecto desta invisibilidade fabricada que são os Códigos de Endereçamento Postal (CEP), obrigatórios na norma urbana vigente, mas que não contemplam a urbanidade produzida nas localidades vulnerabilizadas (favelas). Em linhas gerais todo o tecido urbano da Cidade do Rio de Janeiro está contemplado pelo respectivo CEP, mas quando se coloca uma lupa nesta observação, identifica-se que determinados CEPs congregam diversos logradouros que em tese deveriam possuir CEPs específicos. Isso ocorre com muita frequência nas favelas cariocas, e no contexto de enfrentamento à Covid-19, trouxe intempéries aos Gestores Públicos no monitoramento dos casos e dos óbitos, e porventura dificultando ações de saúde, em especial de vigilância.

Monitorar casos e óbitos de um determinado agravo numa determinada região tem seu valor em si mesmo. Essa importância, para o planejamento Estatal, eleva-se exponencialmente quando associados a outros dados como cor, raça, renda, nível de escolarização, condição de emprego, etc. Ações que salvam vidas poderão ser concebidas, planejadas, implementadas e avaliadas. Os escassos recursos públicos para políticas sociais, melhor direcionadas. O processo histórico que criou mecanismos de produção de desigualdades sociais e vulnerabilidades enfrentado. Atribuir o CEP, portanto, depreende de um fluxo de ações de regularidade fundiária e ajustes das territorialidades existentes nos grandes centros urbanos, produzindo melhores cenários de planejamento, execução e avaliação de políticas públicas como foco na vida das pessoas. Trata-se de apostar num jogo de ganhaganha. 


\section{Referências}

ALMEIDA, M. da S. Desumanização da população negra: genocídio como princípio tácito do capitalismo. Revista Em Pauta, v. 12, n. 34,p. p. 131- 154,2014.

Artigo: A pandemia de Covid-19 e o isolamento social: saúde versus economia - Coronavírus. , [s.d.]. Disponível em: <https://www.ufrgs.br/coronavirus/base/artigo-a-pandemia-de-covid-19-e-oisolamento-social-saude-versus-economia/> . Acesso em: 29 jun. 2020.

BARROS, G. S. Filtragem racial: a cor na seleção do suspeito. Revista Brasileira de Segurança Pública, São Paulo, v. 2, n. 3, p. 134-155, 2008.

BRUM, Mario Sergio. Cidade Alta: História, memórias e estigma de favela num conjunto habitacional do Rio de Janeiro. Tese de Doutorado em História Social/PPGH-UFF. Niterói, 2011.

CARVALHO, M. A. R. de. "Cidade Escassa e Violência Urbana". In: Série estudos. Iuperj: Rio de Janeiro, n. 91, Agosto, 1995.

DISEASES, T. L. I. Political casualties of the COVID-19 pandemic. The Lancet Infectious Diseases, v. 20, n. 7, p. 755, 1 jul. 2020.

DOMINGUES, C. V.; SIMÕES, L. L. O SIG na gestão pública: análise crítica de um caso bemsucedido - desafios e perspectivas. Exacta, v. 5, n. 2, p. 353-360, 2007.

ESCOREL, S. Reviravolta na saúde: origem e articulação do movimento sanitário. Rio de Janeiro: Editora Fiocruz, 1999.

FERNANDES, T. M.; COSTA, R. G. R. Histórias de pessoas e lugares: memórias das comunidades de Manguinhos. $1^{\text {a }}$ ed. Rio de Janeiro: Editora Fiocruz, 2009. v. I.

FERNANDES, T.; LIMA, A. Poder y política de planificacion habitacional en favelas in Rio de Janeiro de los años 2000. In: POWER AND DEMOCRACY: THE MANY VOICES OF ORAL HISTORY. Barcelona: XVIII IOHA Conference, 2014.

FIOCRUZ. Boletim Socioepidemiológico da Covd-19 nas favelas: análise da frequência, incidência, mortalidade e letalidade por Covid-19 em favelas cariocas. Rio de Janeiro: Número 01/2020.

GOMES, N. L; LABORNE, A. A. de P. PEDAGOGIA DA CRUELDADE: RACISMO E EXTERMÍNIO DA JUVENTUDE NEGRA. Educ. rev., Belo Horizonte, v. 34, e197406, 2018. Disponível em <http://www.scielo.br/scielo.php?script=sci_arttext\&pid=S010246982018000100657\&lng=pt\&nrm=iso $>$. acessos em 29 jun. 2020. Epub 23-Nov-2018. https://doi.org/10.1590/0102-4698197406.

GONCALVES, Rafael Soares. Repensar a regularização fundiária como política de integração socioespacial. Estud. av., São Paulo , v. 23, n. 66, p. 237-250, 2009 . Available from $<$ http://www.scielo.br/scielo.php?script=sci_arttext\&pid=S0103-

40142009000200017\&lng=en\&nrm=iso>. access on 28 July 2020. 
GONCALVES, Rafael Soares. Repensar a regularização fundiária como política de integração socioespacial. Estud. av., São Paulo, v. 23, n. 66, p. 237-250, 2009 .

IRIART, C.; WAITZKIN, H.; BREILH, J.; ESTRADA, A.; MERHY, E. E. Medicina social latinoamericana: aportes y desafíos. Revista Panamericana de Salud Pública, v. 12, n. 2, p. 128 136, ago. 2002.

KEARNS, R.; MOON, G. From medical to health geography: novelty, place and theory after a decade of change. Progress in Human Geography, v. 26, n. 5, p. 605-625, out. 2002.

LANCET, T. COVID-19 in Brazil: “So what?” The Lancet, v. 395, n. 10235, p. 1461, 9 maio 2020.

LEFEBRVE, H. L Droit à la Ville. Paris: Gallimard, 1968.

LIMA, A. L. DA S. Não vou bater palmas para maluco dançar: participação social nas favelas de Manguinhos (Rio de Janeiro, 1993-2011). Tese de Doutorado. Rio de Janeiro: Casa de Oswaldo Cruz, 2017.

LIMA, André Luiz da Silva. O Estado que produz a informalidade: o caso dos Conjuntos Habitacionais de Manguinhos no âmbito do PAC-Favelas. O Social em Questão - Ano XXI - $n^{\circ} 42$ - pg. 311-336 - set a dez/2018.

LIMA, R. S.; RATTON, J. L.; AZEVEDO, R. G. (Org.). Crime, polícia e justiça no Brasil. São Paulo: Contexto, 2014. p. 256-264.

LUZ, M. T. Complexidade do campo da Saúde Coletiva: multidisciplinaridade, interdisciplinaridade, e transdisciplinaridade de saberes e práticas - análise sócio-histórica de uma trajetória paradigmática. Saude soc. [online], v. 18, n. 2, p. 304-311, 2009.

MACHADO DA SILVA, L. A.; LEITE, M. da S. .Favelas e Democracia: temas e problemas da ação coletiva nas favelas cariocas. In: Itamar Silva (org.). Rio - a democracia vista de baixo. Rio de Janeiro, IBASE, 2006.

MARICATO, E. As ideias fora do lugar e o lugar fora das ideias- Planejamento urbano no Brasil. In ARANTES, O., MARICATO, E., VAINER, C. A cidade do pensamento único. Rio de Janeiro: Editora Vozes, 2000.

NUNES, E. D. La salud colectiva en Brasil: analizando el proceso de institucionalización. Salud Colectiva, v. 12, n. 3, p. 347-359, 2016.

PAIVA, C. H. A.; TEIXEIRA, L. A. Reforma sanitária e a criação do Sistema Único de Saúde: notas sobre contextos e autores. História, Ciências, Saúde-Manguinhos, v. 21, n. 1, p. 15-36, mar. 2014.

PANDOLFI, D.; GRYNSZPAN, M. Poder público e favelas: uma relação delicada. In: OLIVEIRA, Lucia Lippi (Org.). Cidade: história e desafios. Rio de Janeiro: FGV, 2002.

PERLMAN, Janice. O mito da marginalidade: Favelas e a política no Rio de Janeiro. Rio de Janeiro, Paz e Terra, 1977. 
RAMOS, S.; MUSUMECI, L. Elemento suspeito: abordagem policial e discriminação na cidade do Rio de Janeiro. Rio de Janeiro: Civilização Brasileira, 2005. p. 229-281.

ROLNIK, Raquel. Exclusão territorial e violência. São Paulo Perspec., São Paulo , v. 13, n. 4, p. 100-111, Dec. 1999 .

ROLNIK, R . É possível política urbana contra a exclusão? In: Serviço Social e Sociedade, São Paulo - Editora Cortez, v. 72, p. 53-61, 2002.

SANNA, F. A. A importância da integração de dados para a qualidade da decisão do gestor público. Brasília, ENAP: 2014.

SANTOS, Carlos Nelson Ferreira dos. Movimentos urbanos no Rio de Janeiro. Rio de Janeiro: Jorge Zahar, 1981

SMITH, A. A riqueza das nações - investigação sobre sua natureza e suas causas. São Paulo: Abril Cultural, 1983.

SOUZA e SILVA, J. Favelas: As formas de ver definem as formas de intervir. Revista Econômica, Rio de Janeiro, v 13, n 1, junho 2011.

SOUZA, M. L. de. O tráfico de drogas no Rio de Janeiro e seus efeitos negativos sobre o desenvolvimento sócio-espacial. Cadernos IPPUR/UFRJ, ano VIII, No 2/3. Rio de Janeiro, pp. 2539, 1996.

VALLADARES, Lícia do Prado. A invenção da favela: do mito de origem a favela.com. Rio de janeiro: Editora FGV, 2005.

VARGAS, J. C. A diáspora negra como genocídio: Brasil, Estados Unidos ou uma geografia supranacional da morte e suas alternativas. Revista da Associação Brasileira de Pesquisadores/as Negros/as (ABPN), v. 1, n. 2, p. 31-66, 2010.

ZALUAR, A. Integração perversa: pobreza e tráfico de drogas. Ed. FGV, Rio de Janeiro, 2004.

ZALUAR, Alba. As Classes populares urbanas e a lógica do 'ferro e fumo'. In: Condomínio do Diabo. Rio de Janeiro, Ed. Revan /Ed. UFRJ, 1994. 
http://dx.doi.org/10.18542/rmi.v14i22.9642

\title{
O DISPOSITIVO PEDAGÓGICO DAS REVISTAS CONTIGO! E ROLLING STONE EM RELAÇÃO A PABLLO VITTAR
}

\author{
THE PEDAGOGICAL DEVICE OF THE MAGAZINES WITH YOU! AND ROLLING STONE \\ IN RELATION TO PABLLO VITTAR \\ Julian Junior dos Santos BARBOSA ${ }^{1}$ \\ Universidade Federal de Mato Grosso (UFMT) \\ Fernando ZOLIN-VESZ ${ }^{2}$ \\ Universidade Federal de Mato Grosso (UFMT)
}

Resumo: Este artigo analisa as edições n. $2.192 e$ 137 das revistas Contigo! e Rolling Stone, publicadas respectivamente em setembro de 2017 e janeiro de 2018. Tais revistas apresentam práticas linguísticas em relação à cantora Pabllo Vittar que parecem desestabilizar o binômio masculino-feminino, constituinte do que se convencionou denominar língua portuguesa. A construção do corpus de análise pauta-se na pesquisa documental, sendo formado por quinze excertos retirados de ambas as revistas analisadas. Os resultados sugerem que as revistas funcionam como um dispositivo pedagógico que, por meio das práticas linguísticas relacionadas a Pabllo Vittar, nos ensinam modos outros de ser e estar no mundo social.

Palavras-Chave: concepção de língua; binômio masculino-feminino; dispositivo pedagógico

\begin{abstract}
This paper analyses the editions n. 2.192 and n. 137 of Contigo! and Rolling Stone magazines, which were published respectively in September, 2017 and January, 2018. Those magazines introduce linguistic practices related to the singer Pabllo Vittar that seem to desestablish the masculine-feminine binomial, which constitutes what is considered as the Portuguese language. Results suggest that the magazines function as a pedagogical device that, among the linguistic practices related to Pabllo Vittar, teach us other ways of being and living in the social world.
\end{abstract}

Keywords: concept of language; masculinefeminine binomial; pedagogical device

\footnotetext{
1 Mestre em Estudos de Linguagem pelo Programa de Pós-Graduação em Estudos de Linguagem (PPGEL) da Universidade Federal de Mato Grosso (UFMT). E-mail: yure lua@ hotmail.com

${ }^{2}$ Professor do Departamento de Letras e do Programa de Pós-Graduação em Estudos de Linguagem (PPGEL) da Universidade Federal de Mato Grosso (UFMT).E-mail: fernando_vesz@ hotmail.com
} 


\section{Introdução ${ }^{3}$}

Desde seu surgimento ao grande público, a cantora ${ }^{4}$ Pabllo Vittar tem provocado certo furor devido à referência a práticas linguísticas, consideradas do gênero feminino em língua portuguesa, porém empregadas em associação com elementos classificados como pertencentes ao gênero masculino da língua. Assim, comentários como "Causa-me indignação ler que Pablo Vittar é ‘cantora'. Pablo é nome masculino [...] Então é CANTOR”, retirado da revista eletrônica $O$ Tempo ${ }^{5}$, tornaram-se recorrentes em matérias sobre Pabllo Vittar, sobretudo quando revistas e sites enunciam a cantora com elementos femininos.

Desse modo, chamam-nos à atenção que, de modo geral, esses comentários preocupam-se em estabelecer a marcação em relação aos gêneros masculino e feminino, reproduzindo uma concepção binária da língua portuguesa - a exemplo do comentário acima, cujo autor se apresenta contrariado ao deparar-se com textos que se referem a Pabllo, um substantivo próprio masculino, como cantora, em vez de cantor. Para esse leitor, é como se a revista online $O$ Tempo deturpasse a língua, o que parece concorrer para a desrregulação da língua portuguesa, além de promover certa "imundície verbal" (BORBA; LOPES, 2018) em relação ao modo como a língua seria "normalmente" utilizada. Essa inflexibilidade parece relacionar-se com o pensamento arborescente (DELEUZE; GUATTARI, 1997, 2014), que contribui para a construção do binômio masculino-feminino na forma como entendemos a língua portuguesa. Assim, quando observam certos usos que ultrapassam as noções pré-estabelecidas por sistemas binários, os próprios usuários da língua sentem-se obrigados em desempenhar o papel de reguladores ou inquisitores legítimos das leis que regem o sistema de determinada língua.

Neste artigo, analisamos as práticas linguísticas apresentadas em torno da cantora Pabllo Vittar nas edições n. 2.192 e 137 das revistas Contigo! e Rolling Stone, respectivamente, publicadas no período compreendido entre setembro de 2017 e janeiro de 2018. Este recorte se relaciona com o período em que Pabllo Vittar começa a figurar nas capas das referidas revistas, após a participação da cantora no festival de música Rock'n Rio, ocorrido em setembro de 2017, na cidade do Rio de Janeiro, e suas músicas iniciam a ocupar as primeiras posições entre as mais executadas em rádios e

\footnotetext{
${ }^{3}$ Este artigo é um recorte modificado da dissertação de mestrado do primeiro autor, defendida no Programa de PósGraduação em Estudos de Linguagem (PPGEL) da Universidade Federal de Mato Grosso (UFMT), sob orientação do segundo autor.

${ }^{4}$ Em virtude da posição teórica adotada nesta pesquisa, referimo-nos a Pabllo Vittar sempre por meio de elementos classificados como femininos na língua portuguesa.

5 Disponível em: <www.otempo.com.br/diversao/mais-ruim-do-que-eu-diz-cantor-falcao-sobre-pabllo-vittar1.1555436>. Acesso em: 28 set. 2019.
} 
serviços de streaming de música no país. Desse modo, buscamos compreender o posicionamento das referidas revistas sobre como referir-se à cantora Pabllo Vittar, mediante uma concepção de língua vigente ainda regularizada pelo binômio masculino-feminino. Para tanto, lançamos mão, inicialmente, do conceito de dispositivo pedagógico da cultura pop.

\section{Cultura pop e as noções de ser e estar no mundo contemporâneo}

Rotular algo como pop pode muitas vezes caracterizar uma adjetivação desqualificadora, de elementos descartáveis pela mídia, ou, por outro lado, atribuir certo prestígio a itens que estão no auge ou que caíram no gosto popular de determinado grupo social. De acordo com Sá, Carreiro e Ferraraz (2015), em ambos os casos, observa-se a dualidade e as controvérsias que assinalam o termo “cultura pop". Assim, destacam os autores, a cultura pop pode expressar um espaço profícuo para embates, tensões, valores e lutas culturais oriundas de várias vertentes midiáticas, tais como cinema, teatro, fotografia, quadrinhos, plataformas digitais, música e, acrescentaríamos, revistas consideradas como de entretenimento, a exemplo das revistas Contigo! e Rolling Stone. Desse modo, conforme Soares (2015), a cultura pop pode ser compreendida para além do consumo, da histeria momentânea, da frivolidade e do supérfluo: conforme o autor, os produtos da cultura pop podem ajudar a articular novas normas de diferenciação nos contextos contemporâneos.

De maneira similar, porém voltando-se para o campo dos estudos midiáticos, Fischer (2012) destaca o papel da mídia como recurso pedagógico. Segundo a autora, a mídia não apenas veicula informação e/ou entretenimento, mas também tece, “[...] constrói discursos e produz significados e sujeitos" (FISCHER, 2012, p. 113). A autora, portanto, preocupa-se em observar a mídia como “dispositivo pedagógico", ou seja, como agente fomentador de determinadas noções e certos saberes a respeito do mundo social: aprendemos modos de ser e estar no mundo por meio da mídia. Como destaca Fischer, a mídia constitui-se como lócus de educação.

De igual modo, a cultura pop pode exercer "[...] profunda influência no(s) modos(s) como as pessoas experimentam o mundo ao seu redor" (SÁ; CARREIRO; FERRARAZ, 2015, p. 9). Sendo assim, também pode compor-se como dispositivo pedagógico, ou seja, consumir um produto proveniente da cultura pop pode ensinar-nos determinadas maneiras de ser e estar no mundo social, engendrando-se, portanto, como lócus de educação. Por exemplo, ler uma revista como Contigo!, considerada apenas como um artefato cultural destinado ao entretenimento, uma vez que desfila matérias e reportagens sobre famosos e celebridades, pode significar aprender modos outros de ser e estar no mundo. Quando uma edição dessa revista estampa na capa a cantora Pabllo Vittar, sob o 
título “Quem é este fenômeno?", e lança mão do uso de elementos masculinos e femininos em uma mesma frase - “a cantora (ou cantor, já que prefere evitar definição de gênero!)” - a própria revista já parece apresentar-se como um dispositivo pedagógico disposto a questionar uma concepção de língua normatizada pelo binômio masculino-feminino.

\section{A concepção de língua para além do binômio masculino-feminino}

Primeiramente, convém pontuar que, neste artigo, o conceito de língua é tomado como processo de invenção, ou seja, como produto da discursivização “[...] no interior de um dispositivo com fins de gestão e controle de povos e de terras" (SEVERO, 2016, p. 12). Por esse viés, segundo a autora, entende-se língua como fruto de um largo processo de criação, controle e gestão de identidades, que não só garantiram a longevidade de certos sistemas, mas também a supremacia diante de outros. É nesse enquadre sócio-histórico que o paradigma monolíngue se instituiu, contribuindo para a manutenção da concepção de língua como um sistema único, estável e livre de quaisquer influências que fujam das características pré-estabelecidas por suas severas normas.

Tal panorama a respeito da constituição da concepção de língua aproxima-se de um sistema filosófico "arbóreo" (DELEUZE; GUATTARI, 2014), o qual se origina de uma semente - fruto da criação - e se desenvolve hierarquicamente por suas raízes, troncos, galhos e frutos. Os autores constroem essa metáfora baseada na ilustração de uma árvore, que funciona principalmente para explicar determinada perspectiva de pensamento delineada sob a necessidade de "uma forte unidade principal, unidade que é suposta para chegar a duas" (DELEUZE; GUATTARI, 2014, p. 20). Sendo assim, a imagem da árvore-raiz atua de acordo com uma lógica binária, que "não para de desenvolver a lei do Uno que devém dois, depois dois que devêm quatro...” (DELEUZE; GUATTARI, 2014, p. 20). Nesse sistema linear, conforme proposto pelos autores, prevalece uma lógica binária, que se refere metaforicamente ao produto originário de um "tronco" que insistentemente se bifurca em ramos específicos. No pensamento arborescente, portanto, há apenas uma linearidade composta por propósitos binários e hierárquicos.

Ainda segundo os autores, esse sistema arbóreo “[...] dominou toda a realidade ocidental e todo o pensamento ocidental, da botânica à biologia, a anatomia, mas também a gnosologia, a teologia, a ontologia, toda a filosofia... o fundamento raiz" (DELEUZE; GUATTARI, 2014, p. 2829). A concepção de língua não passou incólume a todo esse processo. De acordo com Deleuze e Guattari (1997), a língua, no pensamento arborescente, define-se, sobretudo, por um conjunto de ligações com posições fixas, derivadas de uma lógica binária, tais como as conhecidas bases duais da 
gramática normativa: masculino-feminino, singular-plural, substantivo-verbo etc. Isso resultou, segundo Lima e Borba (2016), em determinado tipo de saber que considera apenas duas possibilidades válidas, excluindo e apagando todo e qualquer cenário que escape às duas primeiras proposições. Em relação à concepção de língua, há a instituição de apenas duas possibilidades de gênero para os substantivos, vinculadas à chamada questão lexical das palavras: mulher = feminino e homem = masculino.

Entretanto, como observam Borba e Lopes (2018), os gêneros masculino e feminino não estão relacionados única e exclusivamente a essa suposta natureza lexical, mas atrelados a questões sociais, como é o caso, em língua portuguesa, dos substantivos dotados de um "masculino genérico" para se referir à humanidade como um todo. Este fato, advertem os autores, é tido assim como um "simples fenômeno linguístico e não como um produto de convenções sociais e políticas de sociedades patriarcais" (BORBA; LOPES, 2018, p. 17), entendido muitas vezes como "imundície verbal”, que apenas serve para desestabilizar e "sujar" a língua portuguesa - a exemplo do incômodo do leitor sobre o emprego do substantivo "cantora" em referência a Pabllo Vittar, no comentário retirado da revista eletrônica $O$ Tempo, com o qual abrimos a introdução deste artigo. Lima e Borba (2016) pontuam que a causa de tal desconforto parece estar vinculada ao aparecimento de práticas linguísticas que rompem com o ideal de estabilidade e pureza prescrito pelo paradigma monolíngue.

Como nos lembra Butler (2003), o gênero não é natural, mas socialmente construído. Nesse sentido, destaca a autora, as práticas linguísticas atuam como atos repetidos de resultados "consolidados" que ajudam a constituir a acepção do que é homem e do que é mulher. Em contrapartida, essa mesma perspectiva levanta questionamentos em relação aos possíveis apagamentos e/ou exclusões de identidades díspares, diferentes das que não contemplam o ideal de feminino ou de masculino reafirmados pela linguagem, extrapolando as normatividades para além do binômio masculino-feminino, favorecendo uma abertura de "olhar e das sensibilidades a outras estéticas que desafiam e desnaturalizam hierarquias classificatórias e relações de poder" (LIMA; BORBA, 2016, p. 113). É esse olhar que as revistas Contigo! e Rolling Stone parecem lançar quando estampam a cantora Pabllo Vittar nas capas das edições aqui em análise, constituindo-se como loci de educação.

\section{Procedimentos metodológicos}

Para construção e análise do corpus deste trabalho, adotou-se o método de pesquisa qualitativa, uma vez que possibilita ao pesquisador um "conjunto de práticas materiais e 
interpretativas que dão visibilidade ao mundo" (RAMALHO; RESENDE, 2011, p. 76), por meio das quais o pesquisador poderá descrevê-lo, interpretá-lo e entendê-lo. Assim, como pontuam Ramalho e Resende (2011), obtém-se uma pesquisa em que o pesquisador é "guiado por um conjunto de crenças e de sentimentos em relação ao mundo e ao modo como este deveria ser compreendido e estudado" (RAMALHO; RESENDE, 2011, p. 74). Dentro dessa perspectiva, lançamos mão da pesquisa documental para a construção do corpus, no intento de definir "estratégias para gerar dados que ajudassem a alcançar os objetivos pretendidos e a responder às questões da pesquisa" (RAMALHO; RESENDE, 2011, p. 95).

Desse modo, o corpus, composto por quinze excertos das revistas Contigo! e Rolling Stone, busca analisar as práticas linguísticas empregadas por essas revistas para referir-se à cantora Pabllo Vittar. Para tanto, verifica-se, em cada excerto, três aspectos: (1) o emprego de comentários elucidativos a respeito do uso concomitante dos gêneros masculino e feminino em referência a Pabllo Vittar, (2) a naturalização de tal uso, sem a necessidade de qualquer explicitação sobre tal concomitância, e (3) o privilégio de formas femininas para se referir à cantora.

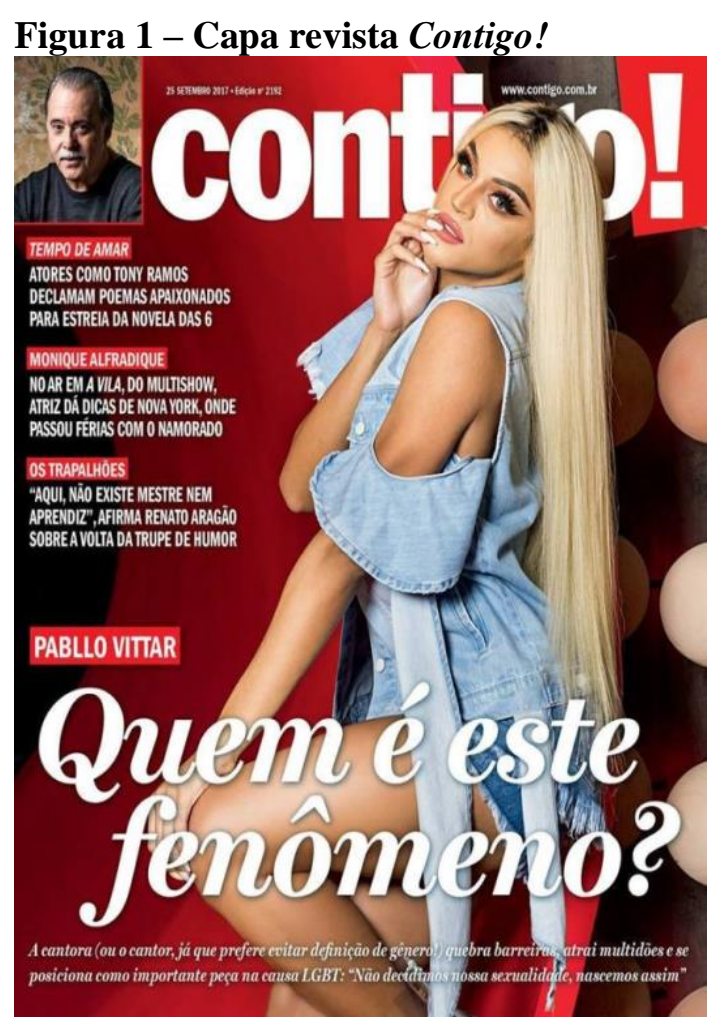

Revista Contigo! - edição n. 2192 (25 de setembro de 2017)
Figura 2 - Capa revista Rolling Stone

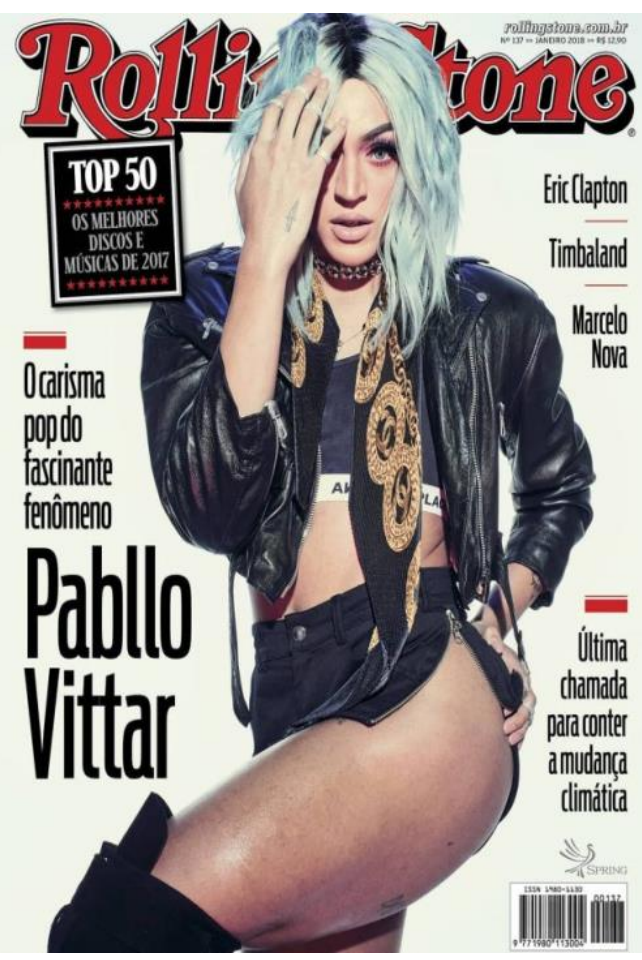

Revista Rolling Stone - Edição n. 137 (janeiro de 2018) 


\section{As práticas linguísticas relacionadas a Pabllo Vittar na Revista Contigo!}

A primeira revista em que Pabllo Vittar aparece como capa é a Contigo!, publicada em 25 de setembro de 2017, logo após a cantora se apresentar no festival Rock'n Rio daquele ano, causando bastante repercussão.

\section{Quadro 1 - Excertos da revista Contigo!}

\begin{tabular}{|c|}
\hline Excertos destacados: \\
\hline $\begin{array}{l}\text { 1. "A cantora (ou o cantor, já que prefere evitar definição de gênero!) quebra barreiras, atrai } \\
\text { multidões e se posiciona como importante peça na causa LGBT: "não decidimos nossa } \\
\text { sexualidade, nascemos assim" }\end{array}$ \\
\hline 2. "Produção sempre assinada por ela (ou por ele, já que artigos não a definem)" \\
\hline $\begin{array}{l}\text { 3. "Muitas vezes, você se chama no masculino, e outras, no feminino... Depende de que, estado } \\
\text { de espírito? - Artigo para definir pessoas é tipo marcar boi, sabe? A gente é livre para ser o } \\
\text { que quiser e eu sou 'o' ou 'a'. Não será uma letra que definirá meu gênero ou quem eu sou" }\end{array}$ \\
\hline 4. "Apesar de ter uma equipe, sua produção é feita por ela" \\
\hline 5. "[...] foi convidada para ser empresariada" \\
\hline 6. “venerada pelo público" \\
\hline 7. "Solteira, ela brinca $[\ldots] "$ \\
\hline $\begin{array}{l}\text { 8. "Fiquei muito honrado, somos grandes amigas (elelela se refere sempre a si mesmo/a } \\
\text { alternadamente) [...]" }\end{array}$ \\
\hline
\end{tabular}

O primeiro excerto a ser analisado, “A cantora (ou o cantor, já que prefere evitar definição de gênero!) quebra barreiras, atrai multidões e se posiciona como importante peça na causa LGBT: 'não decidimos nossa sexualidade, nascemos assim"”, aparece como resposta à pergunta que intitula a capa da edição - "Pabllo Vittar, quem é este fenômeno?" O uso de elementos masculinos e femininos em uma mesma frase - "a cantora (ou cantor...)" - ocorre, a nosso ver, por dois motivos: o primeiro parece estar relacionado à necessidade inicial da revista em apresentar e explicar em que consiste a figura apresentada, uma vez que se trata da primeira revista a vincular, em sua capa, uma artista a qual aceita ser mencionada tanto por elementos femininos como por elementos masculinos; o segundo, decorrente do primeiro, refere-se ao caráter também pedagógico de uma revista como a Contigo!, especializada em retratar a vida de famosos e de celebridades. Como observa Fischer (2012), a preocupação apresentada pela mídia não se vincula apenas a entreter ou a oferecer notícias, mas também se posicionar "como lócus de educação, de formação, de condução da vida e de como esse fato tem importantes repercussões nas práticas sociais" (FISCHER, 2012, p. 113). Nesse sentido, o subtítulo da capa, “a cantora (ou o cantor, já que prefere evitar definição de gênero!)” se encarrega 
em retomar e explicar as questões que circundam a figura de Pabllo Vittar - uma artista, que possui um nome masculino, mas que aceita ser tratada tanto como cantor quanto como cantora.

Sob essa perspectiva, observa-se uma matéria dividida em dois momentos: no primeiro, constante inicialmente da capa da revista, parece haver a preocupação em explicar e definir o emprego concomitante dos gêneros masculino e feminino para se referir a Pabllo Vittar; no segundo instituídas as devidas explicações -, a livre utilização de elementos masculinos e femininos em uma mesma frase. Isso ocorre, a nosso ver, porque inicialmente se torna preciso explicar como uma cantora, a qual apresenta um nome masculino, se apropria de elementos linguísticos que transitam pelo binômio masculino-feminino com a finalidade de construir sua performance artística. Ademais, tal explicação consolida as escolhas linguísticas apresentadas pela revista no decorrer da matéria.

No excerto subsequente da matéria, a não regularidade do uso e concordância com o gênero é retomada no excerto "Produção sempre assinada por ela (ou por ele, já que artigos não a definem)", constante do parágrafo de introdução da entrevista. Tal excerto, além de resgatar o caráter pedagógico apresentado no subtítulo da capa da revista, relaciona-se, em particular a explicação entre parênteses, com a resposta da terceira pergunta da entrevista: "Muitas vezes, você se chama no masculino, e outras, no feminino... Depende de que, estado de espírito?" A resposta dada pela cantora ganha ênfase na página seguinte - "Artigo para definir pessoas é tipo marcar boi, sabe? A gente é livre para ser o que quiser e eu sou 'o' ou 'a'. Não será uma letra que definirá meu gênero ou quem eu sou” -, retomando o caráter pedagógico que a revista, por ser a responsável em apresentar Pabllo Vittar ao grande público, parece assumir, em particular no que se refere à preocupação em explicar e definir o emprego concomitante dos gêneros masculino e feminino para aludir à cantora.

Portanto, dado o devido destaque, uma vez mais, à explicação sobre as práticas linguísticas relacionadas a Pabllo Vittar, a revista parece ampliar seu posicionamento em relação a não normatividade em concordar elementos masculinos com masculinos, ou femininos com femininos. Sempre se referindo a Pabllo Vittar no gênero feminino, tal premissa pode ser constatada nos excertos 4, 5, 6 e 7: "Apesar de ter uma equipe, sua produção é feita por ela”, “[...] foi convidada para ser empresariada", "venerada pelo público" e "Solteira, ela brinca [...]”, os quais compõem legendas de fotos e perguntas da entrevista. De igual modo, quando a cantora se refere a si mesma durante a décima segunda pergunta da entrevista - "Anitta quis te empresariar e você recusou. Isso gerou algum ruído na relação de vocês?" - a coexistência entre elementos masculinos e femininos no excerto que constitui o início da resposta à pergunta - "Fiquei muito honrado, somos grandes amigas (elelela se refere sempre a si mesmo/a alternadamente) [...]", bem como a retomada, constante entre parênteses e em itálico, da explicação do emprego conjunto dos gêneros masculino e feminino para remeter a 
Pabllo Vittar, parece recuperar a análise das práticas linguísticas sobre a cantora desenvolvidas ao longo desta primeira seção.

\section{As práticas linguísticas relacionadas a Pabllo Vittar na revista Rolling Stone}

Importante publicação nas áreas da música e da cultura pop, a revista Rolling Stone, edição publicada em janeiro de 2018, cuja matéria de capa intitula-se "O carisma pop do fascinante fenômeno Pabllo Vittar”, parece caminhar para a naturalização, sem qualquer indício de necessidade de alguma elucidação, a respeito do emprego simultâneo dos gêneros masculino e feminino quando a matéria reporta-se a Pabllo Vittar: a revista parece sentir-se "muito à vontade" para empregar elementos femininos, mesmo referindo-se a um nome artístico na forma masculina, sem qualquer necessidade de alguma adenda que vise a explicar tal uso.

\section{Quadro 2 - Excertos da revista Rolling Stone}

\begin{tabular}{|l|l|}
\hline Excertos destacados: \\
\hline 1. & "[...] onde fica o estúdio em que ela gravaria algumas horas depois. A cantora sacou um celular \\
para trilhar o nosso encontro e ela mesma ficou surpresa ao ouvir que uma faixa sua estava ali \\
naquela playlist. Desmontada, com os cabelos curtos à mostra e calçados chinelos, ela sai mais \\
tímida [...]"
\end{tabular}

Nos excertos destacados acima, apesar de todos referirem-se a Pabllo Vittar, a revista Rolling Stone alude à cantora sempre no gênero feminino - desde o excerto 1, constante do parágrafo que abre a reportagem, até o excerto 7, encontrado na penúltima página da reportagem, registram-se cinco ocorrências do pronome pessoal "ela" (nos excertos 1, 3 e 4), bem como uma ocorrência da forma 
contraída "dela" (no excerto 2) na função de pronome possessivo, e outra ocorrência do pronome oblíquo "a" (no excerto 3). Além disso, o substantivo "cantora" é empregado três vezes (nos excertos 1, 2 e 6) e o adjetivo "brasileira" consta em dois dos excertos (5 e 7). Sobre adjetivações, sempre que usadas em menção a Pabllo Vittar, são registradas no feminino, como "desmontada", nos excertos 1 e 6, "desconhecida" e "abalada", ambas no excerto 3, "cansada", no excerto 6, e "seguida", no excerto 7. Esse traço acerca do predomínio do gênero feminino para referir-se à cantora não requer a necessidade do selo de esclarecimento sobre a primazia das referências a Pabllo Vittar no feminino a revista sente-se "muito à vontade" para utilizar elementos femininos em referência a um nome artístico que se apresenta na forma masculina.

Nesse andar, o emprego dos sintagmas "uma Pabllo", no excerto 3, e "uma Pabllo Vittar", no excerto 6, parecem convergir para esse entendimento da revista Rolling Stone apresentado no final do parágrafo anterior, ou seja, a comodidade da revista em empregar o pronome indefinido "uma" acompanhando o substantivo próprio "Pabllo (Vittar)". Considerando que "Pabllo" é um substantivo próprio "masculino", o posicionamento da revista parece flutuar para além das noções de feminino e de masculino, conectando elementos linguísticos que não parecem obedecer à ordem binária preestabelecida na língua portuguesa, conforme destacada por Deleuze e Guattari (1997). Em outras palavras, dilui a concordância de gênero que tal construção linguística demandaria, ou ainda, o próprio binômio masculino-feminino que organiza e estrutura nosso entendimento acerca de concordância nominal entre pronome e substantivo. Esse posicionamento parece conduzir a outro entendimento sobre o caráter pedagógico da cultura pop, observado, ainda que em grau diferente, na análise precedente da revista Contigo! - sem a necessidade de explicar esses usos linguísticos, mas de certa forma naturalizando-os, empregando-os sem a obrigação de qualquer comentário elucidativo em relação a esses usos. É nesse clima de não demarcação binária do gênero, de alternância entre as formas masculina e feminina, mas também privilegiando as formas femininas para se referir a Pabllo Vittar, que ambas as revistas aqui analisadas parecem contribuir para o (re)dimensionamento do binômio masculino-feminino constituinte da concepção de língua.

\section{Considerações finais}

Neste artigo, analisamos as práticas linguísticas relacionadas à cantora Pabllo Vittar nas edições n. 2.192 e 137 das revistas Contigo! e Rolling Stone, respectivamente, publicadas no período compreendido entre setembro de 2017 e janeiro de 2018, de modo a compreender o posicionamento das referidas revistas sobre como referir-se à cantora Pabllo Vittar, mediante uma concepção de língua 
pautada pelo paradigma monolíngue (e suas características pré-estabelecidas por severas normas), herdeiro do pensamento arborescente, com suas posições fixas e sua lógica binária, o qual contribui para o apagamento e/ou a exclusão de quaisquer influências que fujam de suas características "naturais", rotulando-as como "imundície verbal" que apenas serve para desestabilizar a língua portuguesa e suas bases duais.

O posicionamento das revistas aqui analisadas parece reafirmar o caráter pedagógico da cultura pop para além do consumo, da frivolidade e do supérfluo: seja por meio de comentários elucidativos a respeito do uso concomitante dos gêneros masculino e feminino para se referir à cantora Pabllo Vittar, seja naturalizando tal uso, sem a necessidade de qualquer explicitação sobre tal concomitância, ou ainda privilegiando as formas femininas para se referir a Pabllo Vittar, ambas as revistas parecem contribuir para o (re)dimensionamento do rígido binômio masculino-feminino constituinte da língua portuguesa. De fato, conforme abordamos em outro passo, aprendemos modos outros de ser e estar no mundo por meio da cultura pop, ou, como diria a própria Pabllo Vittar na entrevista para a revista Contigo!, “a gente é livre para ser o que quiser e eu sou 'o' ou 'a'. Não será uma letra que definirá meu gênero ou quem eu sou". Talvez ler revistas consideradas apenas como “de entretenimento" possa apresentar um caráter pedagógico mais condizente com os tempos atuais.

\section{Referências}

BORBA, R; LOPES A. C. Escrituras de gênero e políticas de différance: imundície verbal e letramentos de intervenção no cotidiano escolar. Linguagem \& Ensino, v. 21, 2018, p. 241-285.

BUTLER. J. Problemas de gênero: feminismo e subversão da identidade. Rio de Janeiro: Civilização Brasileira, 2003.

DELEUZE, G.; GUATTARI, F. Mil platôs - capitalismo e esquizofrenia, vol. 2. Trad. Ana Lúcia de Oliveira e Lúcia Cláudia Leão. São Paulo: Ed. 34, 1. ed., 2. reimp., 1997.

DELEUZE, G.; GUATTARI, F.. Introdução: rizoma. In: DELEUZE, G.; GUATTARI, F. Mil platôs - capitalismo e esquizofrenia, vol. 1. Trad. Aurélio Guerra Neto. São Paulo: Ed. 34, 2. ed., 1. reimp., 2014, p. 17-49.

FISCHER, R. M. B. Trabalhar com Foucault: arqueologia de uma paixão. Belo Horizonte: Autêntica, 2012. 
LIMA, F.; BORBA, R. Sobre (des)aprendizagem e multidões queer: rizomas, multiplicidades e a política menor. In: ALVES, D. S. (Org.). Gênero e diversidade sexual: teoria, política e educação em perspectiva. Tubarão: Copiart, 2016, p. 79-114.

RAMALHO, V.; RESENDE, V. M. Análise de discurso (para a) crítica: o texto como material de pesquisa. Campinas: Pontes, 2011.

SÁ, S. P.; CARREIRO, R. FERRARAZ, R. (Orgs.). Cultura pop. Salvador: EdUFBA, 2015.

SEVERO, C. G. A invenção colonial das línguas da América. Alfa, São Paulo, v. 1, p. 11-28, 2016.

SOARES, T. Percursos para estudos sobre música pop. In: SÁ, S. P.; CARREIRO, R. FERRARAZ, R. (Orgs.). Cultura pop. Salvador: EdUFBA, 2015, p. 19-33. 
http://dx.doi.org/10.18542/rmi.v14i22.9646

\title{
"BANDIDO BOM É BANDIDO MORTO"? ANÁLISE DO DISCURSO CRÍTICA APLICADA A REAÇÕES SOBRE CHACINAS PUBLICADAS PELO JORNAL DIÁRIO ONLINE EM SUA PÁGINA NO FACEBOOK
}

\author{
"A NICE BANDIT IS A DEAD BANDIT"? ANALYSIS OF THE CRITICAL SPEECH \\ APPLIED TO REACTIONS ON CHACINAS PUBLISHED BY THE ONLINE DAILY \\ NEWSPAPER ON HIS FACEBOOK PAGE
}

Vivianne Carolina Oliveira de Sousa LEITE ${ }^{1}$

Instituto Federal do Pará

Breno Rodrigo de Oliveira ALENCAR ${ }^{2}$

Instituto Federal do Pará

\begin{abstract}
Resumo: Este trabalho apresenta os resultados de uma pesquisa sobre as reações de internautas ao noticiário da violência em redes sociais, em particular aquelas relacionadas às chacinas de Belém (2014), Tapanã (2018) e Guamá (2019) ocorridas na cidade de Belém e publicadas pelo jornal Diário Online (DOL) em sua página no Facebook. Por meio de dele procuramos identificar padrões de reações às manchetes; analisar a intencionalidade das manchetes do jornal Diário Online; e interpretar os significados sociais em torno de reações dos usuários das redes sociais sobre o fenômeno da violência urbana na cidade de Belém. Para atingir estes objetivos fizemos uso da Análise do Discurso Crítico como metodologia de análise das reações dos internautas às manchetes sobre chacinas publicadas pelo Jornal Diário Online em sua página no Facebook entre os anos de 2016, 2017, 2018 e 2019.
\end{abstract}

Palavras-chave: Chacina. Redes Sociais. Facebook. Análise do Discurso Crítica.

\begin{abstract}
This paper presents the results of research on the reactions of Internet users to the news of violence on social networks, in particular those related to the massacres of Belém (2014), Tapanã (2018) and Guamá (2019) that took place in the city of Belém and published by the newspaper Diário Online (DOL) on its Facebook page. Through it, we seek to identify patterns of reaction to headlines; analyze the intentionality of the headlines in the Diário Online newspaper; and interpret the social meanings around reactions of users of social networks on the phenomenon of urban violence in the city of Belém. To achieve these goals, we used Critical Discourse Analysis as a methodology for analyzing Internet users' reactions to the headlines about massacres published by the Diário Online newspaper on their Facebook page between the years 2016, 2017, 2018, and 2019.
\end{abstract}

Keywords: Massacre. Social networks. Facebook. Critical Discourse Analysis

\footnotetext{
${ }^{1}$ Estudante da Especialização em Saberes, Linguagens e Práticas Educacionais na Amazônia (IFPA/Campus Belém). Email: leitecarol29@gmail.com

${ }^{2}$ Professor e Líder do Grupo de Pesquisa em Cultura, Educação e Política (GICEP) do Instituto Federal do Pará,

Campus Belém. E-mail: breno.alencar@ifpa.edu.br
} 


\section{Introdução}

Conforme observou Castells (1999), a era da informação inaugurou uma nova forma de produção e de consumo de conteúdo. Com o surgimento das redes sociais, este fenômeno alcançou um novo patamar a partir do momento em que as mídias, em especial os jornais de grande circulação, migraram da imprensa tradicional para o ambiente virtual. Se antes o leitor anônimo era visto como mero receptor de seu conteúdo, o avanço dos mecanismos de reação e interação com a notícia lhe deram cada vez mais voz, rosto e protagonismo. O resultado disso é que nos últimos anos a notícia tem sido posta em circulação visando aos usuários das redes sociais, pois é a sua impressão, interpretação e reação que parecem definir o significado dos conteúdos produzidos.

Em se tratando de um ambiente virtual de interação social mediada por conteúdos produzidos por outros usuários, a sensação de "liberdade" é proporcionada na medida em que o leitor enxerga esse ambiente como um "mundo" separado do qual ele vive. Dentro deste movimento de democratização da internet, podemos apontar as práticas associadas ao que ficou conhecido como "discurso de ódio" e suas consequências, como o cyberbullying, o linchamento virtual e, mais recentemente, o cancelamento. Trata-se de fenômenos contemporâneos à ascensão de visões ultraconservadoras ou reacionárias que descambam para o racismo, a xenofobia ou o incentivo a ações estatais ou paramilitares que ferem convenções de direitos humanos sob a alegação de que "bandido bom é bandido morto".

Este tipo de declaração ganhou o imaginário social brasileiro ao longo das décadas de 2000 e 2010 através de programas de televisão cuja audiência fora potencializada por reportagens sensacionalistas e o sentimento de indignação da população com a segurança pública. A expressão, no entanto, passou a fazer parte do cotidiano ao ser naturalizada pelo então candidato e atual presidente da república, Jair Bolsonaro, e seus eleitores/seguidores, em circunstâncias cujos crimes significassem uma forma de "fazer justiça com as próprias mãos", a exemplo do sentido atribuído às chacinas ocorridas em áreas urbanas.

Além de estar presente em comentários em relações presenciais, a expressão "bandido bom é bandido morto" também passou a fazer parte de textos, vídeos e comentários despertando ora indignação, ora simpatia. Por essa razão, o presente artigo se dedica a avaliar a percepção dos usuários de redes sociais tendo como referência o significado atribuído a esta expressão por meio de notícias acerca de chacinas em áreas urbanas.

Quanto a escolha do tema, ressaltamos que foi levado em consideração a grande repercussão das chacinas na sociedade belemense e seu impacto causado nos meios de comunicação local, que ao 
longo da última década tem se aproveitado da violência para estampar em suas páginas, sejam elas impressas ou virtuais, manchetes sensacionalistas que têm atraído o leitor/usuário para conhecer detalhes do ocorrido, seja visualização de vídeos e/ou imagens de vítimas, seja identificação de atores associados às chacinas, como as milícias armadas e o temido "carro prata".

Do mesmo modo, salientamos que as chacinas ocorridas em Belém são um fenômeno que vêm se repetindo há mais de 25 anos e o intervalo entre os acontecimentos está se reduzindo atestando a recorrência desse tipo de violência em alguns bairros, conforme demonstrou o documento da Comissão Parlamentar de Inquérito para apuração de grupos de extermínio e milícias no estado do Pará: relatório final, que foi produzido pela Assembleia Legislativa do Estado do Pará (PARÁ, 2015), no qual há o registro das chacinas do bairro do Tapanã, em 1994; chacina do bairro Paar, em 1995; chacina do bairro de Icoaraci, em 2011; chacina de Belém (ocorrida em seis bairros), em 2014; chacina da RMB e a chacina do bairro da Condor, em 2017.

\section{Método e teoria da análise do discurso}

Primeiramente, é importante frisar a escolha do jornal, e consequentemente, da fanpage analisada. Essa página foi escolhida por representar um dos maiores jornais do estado do Pará, portanto com grande visibilidade para a atração de interação dos usuários. Posteriormente, foram escolhidos nas mesmas datas os comentários utilizando o filtro "mais relevantes" da própria plataforma, pois estes contêm o maior número de reações dos internautas.

Também é importante esclarecer que este trabalho é fruto de uma disciplina chamada "Discursos midiáticos: cinema e televisão", da pós-graduação lato sensu Saberes, Linguagens e Práticas Educacionais na Amazônia do Instituto Federal de Educação, Ciência e Tecnologia do Pará, campus Belém. Além do mais, foi desenvolvido a partir da linha de pesquisa "Saberes, Imagens e Tecnologias Audiovisuais" do Grupo Interdisciplinar de Estudos e Pesquisas em Cultura, Educação e Política (GICEP) do Instituto Federal do Pará, Campus Belém.

Nesse sentido, a primeira ação da pesquisa se deu pela escolha das manchetes que tinham como temática comum as chacinas que ocorreram nos bairros de Belém. Foi feita a visita à página do jornal Diário Online, no Facebook, assim como uma pesquisa na aba de publicações utilizando o termo "chacina". Mediante a isso, as chacinas com a maior quantidade de materiais publicados na fanpage foram as escolhidas para pesquisa. A análise acontece em torno de três chacinas ocorridas 
na cidade de Belém entre os anos de 2014 e 2019, conhecidas como “chacina de Belém” (2014), “chacina do Tapanã" (2018) e "chacina do Guamá" (2019).

Posterior à escolha das manchetes, a segunda ação foi recorrer à análise das interações produzidas pelos leitores da página do jornal Diário Online no Facebook através dos ícones ou botões "curti", "amei", "haha", "uau", "triste" e "grr", nos quais as matérias a respeito das chacinas foram veiculadas. Em seguida fora montado um banco de dados com o recorte temporal dos anos dos acontecimentos.

Como base teórica, a pesquisa recorreu à Análise do Discurso Crítica (ADC), formulada pelo do modelo tridimensional de Fairclough (1995). Assim, a terceira ação da pesquisa foi analisar os dados coletados procurando identificar os três recursos discursivos presentes na interação dos usuários com a rede social, quais sejam: texto (escrita), prática discursiva (processos de produção, distribuição e consumo dos textos) e eventos discursivos como instâncias da prática sociocultural.

Segundo este método, análise do objeto se divide em três partes: Eventos Sociais (texto): Vocabulário, gramática, coesão e estrutura textual; Práticas Sociais (ordens do discurso): Tipos de fala, coerência e intertextualidade; Estruturas Sociais (linguagem): ideologia e hegemonia. Este foi o método aplicado nos comentários e nas reações. É importante citar que as categorias da ADC baseadas no modelo tridimensional de Fairclough escolhidas para analisar as reações às manchetes das postagens do DOL foram "Práticas Sociais" e "Estruturas Sociais", já que estas mais se adequam ao objeto.

Mas para que se obtenha uma maior compreensão do que é a ADC, é importante fazer um breve "passeio" histórico para chegar até o que hoje conhecemos. Começando pelo Estruturalismo, desenvolvido nos anos 30 pelo linguista Ferdinand de Saussure, sua base teórica reconhecia a língua como uma mera estrutura ou um sistema, logo não se fazia relação entre o sujeito e seu contexto. Porém, foi de extrema importância para o desenvolvimento dos estudos linguísticos futuros. No estruturalismo, o conceito de discurso trabalhado é o de um amontoado de palavras e vocábulos, assim como o sujeito é apenas aquele que reproduz esse sistema da língua simplesmente para decifrá-lo.

Seguindo para a Sociolinguística, trabalhada a partir de 1960, cujo estudioso principal foi William Labov, abordava a relação entre a língua e a sociedade no que tange as variáveis sociais. Nota-se uma mudança da corrente anterior a esta, haja vista que o entrelace da língua e sociedade já era possível nesse momento, mas não o suficiente.

Um pouco mais adiante, em 1968, a Análise do Discurso surge, na França, pelos estudos de Michel Pecheux. Essa corrente teórica misturava a linguística com a teoria social e a teoria do sujeito. 
Percebe-se que os estudos já perpassam mais o campo sociológico, sendo uma mudança fundamental para a criação da ADC. Contudo, o discurso é tido como a concretização de ideologias, e o sujeito, seu repositório.

Na década de 70, houve o surgimento da Linguística Crítica. Michel Halliday é o nome principal para essa corrente dos estudos linguísticos. De acordo com a LC, a teorização da linguagem nada mais é do que uma intervenção nela, por ela mesma com o objetivo de chegar à estrutura social. A grande contribuição para a ADC foi a Análise Funcional da Sentença que consiste na identificação das três funções sociais da linguagem.

Para a análise teórica realizada no presente trabalho, utilizou-se outro ramo de estudos advindos da AD: a Análise do Discurso Crítica. Na obra Análise de Discurso Crítica para linguistas e não linguistas, organizado por Batista Jr. (2018), é apresentada a concepção do sujeito como um dos principais pontos de discrepância entre AD e ADC. Para a primeira, o sujeito é julgado em suas interações sociais, discursivamente dadas e, além disso, o sujeito é visto como assujeitado pelo próprio discurso. Já para a ADC, o sujeito é construído e constrói seus processos discursivos. Também é demonstrada as semelhanças e diferenças entre os ramos de estudo da seguinte forma:

AD e ADC preocupam-se com relações de poder e ambas têm o discurso como objeto de análise, porém, para a ADC, a relação entre discurso e práticas sociais é dialética, os sujeitos sofrem e atuam sobre esses discursos e vice-versa [...]. A ADC busca ser uma prática social transformadora da sociedade porque atribui aos analistas o papel de interventores sociais por meio de seu trabalho de análise, opondo-se às estratégias e aos discursos das elites. (BATISTA JR., 2018, p. 63.)

Sobre a Análise do Discurso, Brandão em sua obra Introdução à Análise do Discurso define:

Inscrevendo-se em um quadro que articula o linguístico com o social, a AD vê seu campo estender-se para outras áreas do conhecimento e assiste-se a uma verdadeira proliferação dos usos da expressão "análise do discurso". A polissemia de que se investe o termo "discurso" nos mais diferentes esforços analíticos então compreendidos faz com que a AD se mova num terreno mais ou menos fluido. (BRANDÃO, 2004, p. 16)

As abordagens de investigação linguística se subdividem em abordagens formalista e funcionalista. Esta analisa as formas por função da linguagem; aquela, analisa a estrutura de sistemas das formas de uma língua. Tais abordagens originam-se de duas definições distintas de discurso: "no paradigma formalista, o discurso é definido como unidade acima da sentença; no funcionalismo, como a linguagem em uso." (RESENDE, 2019 p. 14). Porém, Schiffrin (1994) notou um equívoco: o discurso e as sentenças não têm estruturas convergentes, assim como as sentenças são parte do discurso. Logo, não se pode analisar separadamente um elemento fora daquilo que o constitui. 
Sendo assim, a abordagem formalista mostrou-se mais cabível para a aplicação prática haja vista que procura entender como os sistemas linguísticos operam nos eventos da linguagem, bem como constituem as relações sociais na sua ordenação e nas controvérsias das primazias no discurso.

Então, a ADC vem da necessidade de equilibrar a forma e a função da linguagem no que tange à análise. Essa necessidade advém também de que não se pode limitar os estudos da linguagem a uma análise convencional, tampouco restringi-los à análise do contexto social. Portanto, a ADC se configura como mais adequado ao objeto de estudo aqui analisado, as chacinas, uma vez que possui uma abordagem transdisciplinar que alia os estudos da forma e socio-discursivos.

Desse modo, associando-se à Linguística Crítica, a ADC surge, na década de 80, por meio de Norman Fairclough, linguista britânico que tem o contexto não necessariamente ligado ou reduzido ao conceito presente na linguística sistemática, mas sim no que há de político no exercício da língua, afinal, a linguagem é uma prática social.

Situado na Universidade de Lancaster, Fairclough assinalou o termo "Análise de Discurso Crítica" ao publicar um artigo em 1985, no Journal of Pragmatics. Situando-a de modo disciplinar, a ADC dá continuidade aos estudos da Linguística Crítica cujo desenvolvimento se deu na Universidade de East Anglia (RESENDE, 2019, p. 14). Assim sendo, é um equívoco afirmar que este método de análise seja uma ampliação da Análise do Discurso Francesa, posto que procede de áreas dispares dos estudos linguísticos.

Foi em outra obra do autor, Language and Power (2001 [1989]), que a ADC começou a ser consolidada como uma ciência cuja criticidade sobre a linguagem era a principal abordagem. Norman, "visava a contribuir tanto para a conscientização sobre os efeitos sociais de textos como para mudanças sociais que superassem relações assimétricas de poder" (RESENDE, 2019 p. 22). Aproximando-se dos estudos de Bakthin (2002), o estudo crítica tem como objetivo mostrar aproximações e intenções veladas, em contrapartida, proporcionar uma intercessão social corroborando com a transformação daqueles que se encontram em um contexto prejudicial (FAIRCLOUGH, 2001, p. 28). Em vista disso, ele propõe uma "análise de discurso orientada linguisticamente e um pensamento social e político relevante para o discurso e a linguagem na forma de um quadro que será adequado para uso na pesquisa científica social e, especificamente, no estudo da mudança social" (FAIRCLOUGH, 2001 p. 89).

A fim de atingir este propósito, “a ADC assenta-se, primeiro, em uma visão científica de crítica social, segundo, no campo da pesquisa social crítica sobre a modernidade tardia, e terceiro, na teoria e na análise linguística e semiótica.” (RESENDE, 2019 p. 22). Esse tipo de pesquisa, em âmbito 
social, visa promover uma base científica que tenha subsídio para questionamentos que analisam a vida no que se refere à justiça social e o poder. (RESENDE, 2019 p. 23)

A abordagem de análise da ADC chama-se a Teoria Social do Discurso cujo desenvolvimento também se deu por Fairclough. Essa teoria tem dois conceitos principais: discurso e prática social. Associando esses dois conceitos pode-se entender que o discurso não só é uma prática que se dá no âmbito social como também constitui identidades sociais. A TSD fornece um modelo teóricometodológico que trata de diversificadas práticas existentes na vida social cujas estruturas são o encadeamento dos recursos linguísticos aplicados pelos atores sociais e grupos sociais inseridos por intermédio da prática discursiva (RESENDE, 2019, p. 27).

A TSD dispõe de um modelo tridimensional (FAIRCLOUGH, 2001) contendo os seguintes elementos: prática social, tex to e prática discursiva. Cada uma delas possui suas respectivas categorias de análise, que funcionam como organizadoras da análise. Ambas podem ser representadas como segue:

Figura 1 - Concepção tridimensional do discurso em Fairclough (2001)

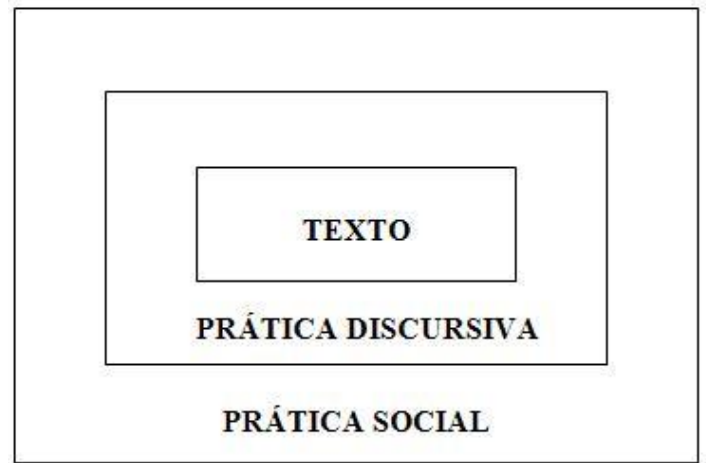

Quadro 1 - Categorias analíticas propostas pelo modelo tridimensional de Fairclough (RESENDE, 2019)

\begin{tabular}{|l|l|c|}
\hline \multicolumn{1}{|c|}{ TEXTO } & PRÁTICA DISCURSIVA & PRÁTICA SOCIAL \\
\hline Vocabulário & Produção & Ideologia \\
\hline Gramática & Distribuição & Sentidos \\
\hline Coesão & Consumo & Pressuposições \\
\hline Estrutura social & Contexto & Metáforas \\
\hline \multirow{3}{*}{} & Força & Hegemonia \\
\cline { 2 - 2 } & Coerência & $\begin{array}{l}\text { Orientações econômicas, } \\
\text { políticas, culturais, } \\
\text { ideológicas }\end{array}$ \\
\cline { 2 - 3 } & Intertextualidade & \\
& & \\
\hline
\end{tabular}


Como na ADC a linguagem é vista como prática social, é necessário levar o contexto em conta a fim de se desvelar o que está por trás do discurso - o que influenciou as escolhas linguísticas, discursivas e textuais. É através da ADC que é possível analisar os processos de dominação que ocorreram - e ainda ocorrem - no mundo. A utilização do domínio das palavras foi capaz de dominar nações, sem que houvesse noção do poder de manipulação. É esse poder de manipulação que ainda se instaura em muitos meios sociais e é papel da ADC buscar analisar tais influenciadores.

A ADC é transdisciplinar visto que atravessa os estudos linguísticos e sociológicos para promover a reflexão sobre como a língua pode perpetuar desigualdades sociais. Sendo assim, necessário também conhecer alguns conceitos básicos dela, a saber: discurso, poder, hegemonia e ideologia. No que tange ao primeiro conceito, a obra de Batista Jr. o define da seguinte forma: "[...] é linguagem como forma de prática social, e não puramente individual ou situacional.”. (BATISTA JR., 2018, p. 57). Visto que a ADC se baseia nos estudos de Fairclough, discurso relaciona-se à texto e interação e é influenciado por crenças, valores e desejos dos atores sociais envolvidos. Para Orlandi (1993), discurso se constitui como uma prática e não um conjunto de textos e está relacionado a enunciação.

Em ADC, poder não está relacionado a um sujeito em si, mas "ao conjunto de relações que permeiam o corpo social” (BATISTA JR., 2018, p. 58). Ou seja, em sua base há a ideia de dominação e, consequentemente, atrela-se também o conceito de hegemonia. Esta, por sua vez, trata-se de uma "relação de dominação baseada no consentimento, que envolve a naturalização de práticas, daí o conceito de hegemonia enfatizar a importância da ideologia" (BATISTA JR., 2018, p. 59). Revisitando o conceito de Gramsci (1988), os pesquisadores ressaltam ainda que hegemonia corresponde a tentativa de universalizar o particular.

Quanto a ideologia, Batista Jr. baseia-se no conceito de Thompson (1995) o qual afirma que ideologias são formas como o sentido serve para compor e sustentar relações de dominação. Tal conceito relaciona-se também com o que está sendo dito e por quem dentro de um discurso e com qual objetivo é feita a enunciação - é a ideologia que sustenta e estabelece relações de dominação e pode estar presente ou não nos discursos. Por fim, compreender o discurso a ser analisado como uma prática social - realizada em determinado momento e socialmente constituída - e como prática discursiva - presente dentro da prática social, envolve contextos específicos - ajudará o analista do discurso a realizar a pesquisa.

Além disso, é através dos gêneros textuais que são utilizados para análise do uso em sociedade e sua multiplicidade que é possível interpretar os discursos feitos em cada contexto social. Ainda 
sobre esses discursos e seu poder sobre os atores sociais afirma-se em Análise do Discurso para Linguistas e Não-Linguistas:

É importante perceber os mecanismos de convencimento implícitos em determinados textos que manipulam o pensamento das pessoas. Com eles, a sociedade pode ser controlada e submetida à dominação política cultural. Se a ADC considera os sujeitos ativos, e não passivos, ponderamos que, quanto mais esclarecidos forem os cidadãos, mais perceberão quando estão sendo controlados e mais resistentes se tornarão aos processos de dominação (BATISTA JR., 2018, p. 50).

A partir dessa concepção compreendemos a importância da conscientização de cada indivíduo em saber assimilar as informações que chegam até eles, o modo e intuito no qual elas são trabalhadas, o contexto que estão vivendo e as possíveis motivações que levam aqueles que discursam a transmitir determinados textos, não se deixando levar pelos discursos minuciosamente elaborados.

\section{Emoção, interação e informação: a sociabilidade no Facebook}

Em termos gerais, as emoções, os sentimentos e as expressões de afeto, embora variem semanticamente, possuem estreita relação entre si, podendo ser descritos como reações de natureza fisiológica e intersubjetiva (cognitiva) a fenômenos naturais ou culturais. Elas fazem parte de esquemas ou padrões de ação apreendidos em interação com o ambiente social e cultural, que são internalizados no início da infância e acionados de acordo com cada contexto (REZENDE e COELHO, 2010, p. 30).

Ao nos referirmos as emoções no mundo virtual, é importante reconhecer que elas têm procurado mecanismos ou ferramentas para sua expressão, como demonstram os ícones ou botões de aplicativos, como os existentes no Facebook, no Instagram, no Twitter ou no Tinder. É por meio deles que somos capazes de exprimir nossas reações a textos, sons ou imagens que, em sua totalidade, representam sentimentos socialmente compartilhados. Mas a expressão social das emoções no mundo virtual, assim como nos contextos de interação presencial, tem acompanhado o desenvolvimento da tecnologia e se adaptado as suas finalidades e características culturais.

Essa interação toda só foi possível por meio da evolução da comunicação digital, pois a distribuição de dados passou a se propagar com maior velocidade, intensificando o processo de atualização informativa e interação dos usuários. Esse longo alcance de informações tornou-se possível através da internet que, por meio de um processo evolutivo, passou a fazer parte do cotidiano das pessoas, tornando mais fácil não só o acesso a conteúdos, mas também a maior interação entre as pessoas. São bem notórias as mudanças que ocorreram com o acesso mais rápido e fácil à internet. Antigamente, a comunicação pela internet se limitava aos e-mails 
e salas de bate-papo, porém seu funcionamento, hoje, se expandiu com as redes sociais e todo o suporte que elas oferecem (SCHROEDER, 2018).

No Brasil, a propagação das redes sociais se deu no início dos anos 2000 por conta da popularização dos smartphones. Obviamente que, hoje em dia, esses dispositivos têm muito mais funções do que as do início, por isso o nome "celular inteligente". Logo, com o avanço tecnológico, abriu-se as portas para a internet. Com esse alcance, o público que antes se limitava a ler notícias passou também a participar ativamente de sua construção, dando opiniões e expressando como se sentem em relação aos fatos que ocorrem no Brasil e no mundo.

A esse respeito disso, Santos e Cypriano (2014) procuram mostrar a aproximação às novas formas da vida social que são vivenciadas nas redes e como a sociabilidade se manifesta nelas. Para isso, os autores utilizam a concepção de Simmel (1983) acerca da "ação recíproca" que possui similaridade com o conceito de sociabilidade cujo ponto de encontro é a reciprocidade das experiências. A teoria simmeliana é apropriada pelos teóricos a fim de evidenciar que há uma ação que resulta numa permuta na vida dos envolvidos de forma acordada e assimilada por eles. Para Georg Simmel, um dos fundadores da sociologia alemã, essa interação é um processo resultante da sociabilidade. Desse modo, para o autor, a sociedade é existente uma vez que a ação de um sujeito tem interferência na vida do outro criando uma coexistência social.

Tendo em vista toda a transformação que a internet sofreu diante das novas demandas de seus usuários, é importante reconhecer o papel que ela tem na vida daqueles que a utilizam. “O que está em jogo aqui é a mudança na utilização da web, que passa de uma ênfase prioritariamente instrumental para uma amplamente relacional" (SANTOS e CYPRIANO, 2014 p. 64, grifos no original). Era instrumental visto que sua utilização tinha fins acadêmicos e profissionais, por exemplo. Contudo, com a explosão das redes sociais, as pessoas assumiram um papel que ampliou essa relação mudando seu o objetivo original.

As redes sociais proporcionam aos seus usuários experiências que excedem o "mundo real" e são nelas que encontram um local de descanso da vida off-line. Sendo assim, escolhem o que podem ser nesse momento de interação, inclusive até criando perfis fakes demonstrando até uma vontade de vivenciar situações que não pertencem à sua identidade original. Isso se dá porque acreditam que a vida ao vivo tem muitos limites com os quais eles não conseguem lidar ou respeitar. Afinal,

É assim que os frequentadores de redes sociais, individualmente ou em coletivos, podem partilhar uns com os outros, muitas vezes de forma imediata, ou um registro em imagem, ou o relato preciso de cada experiência vivida, onde quer que ela se dê, por mais íntima seja, 
desde que as condições tecnológicas de conexão sejam satisfeitas. Pelo afrouxamento dos limites entre a vida puramente subjetiva e a objetiva se apresentam as similaridades pelas quais são tecidos os elos entre indivíduos distintos em suas singularidades. (SANTOS e CYPRIANO, 2014 p. 72).

Lopes e Alves (2011) fizeram um estudo de caso sobre a transformação do vínculo entre a imprensa e a comunidade no que diz respeito à entrada dessas novas vozes por meio das redes sociais. Eles constaram que a internet trouxe a interação que o jornal comum não tinha: a participação dos leitores que são os usuários das redes sociais de hoje. Com isso, o surgimento dos blogs possibilitou que o compartilhamento de notícias deixasse de ser concentrado nas mãos da indústria midiática e deu lugar às pessoas que não faziam parte desse grupo fechado. Isso é denominado no texto como "mídia horizontal” na qual o alcance era muito mais democrático, englobando a participação dos usuários.

E foi a partir dessa "ruptura de papéis" e a maior utilização da internet que corroboraram para o grande consumo das notícias pelas redes sociais. Hoje em dia, é possível encontrar notícias por meio de contas no Facebook, Twitter e Instagram de pessoas que não necessariamente fazem parte da comunidade de jornalistas, mas abrem seus perfis para desempenharem o papel do meio informacional mais dinâmico e acessível para aqueles que não têm mais o costume de comprar jornal impresso. Dessa forma, os perfis dos jornais impressos se popularizaram nas redes sociais fazendo com que a atualização das informações seja instantânea, o que demonstra ser um ganho muito grande para os usuários uma vez que o jornal impresso só noticiava uma vez ao dia devido a produção ser no dia anterior.

Pensando na linguagem jornalística, tudo o que é anunciado é elaborado estrategicamente para atrair o leitor. Admitindo que os jornalistas se utilizam dessas estratégias, é válido se perguntar "o quanto de influência as mídias sociais têm sobre nós?”. Essa pergunta é importante a partir do momento em que assumimos que muitas vezes caímos nesse jogo da conquista por meio de manchetes e imagens que nos chocam. Sendo assim, não é diferente quando se trata de notícias dentro das redes sociais. O jogo é o mesmo, porém é esperado um feedback do leitor por meio das reações ou comentários acerca do conteúdo tratado. Essa interação entre os discursos da postagem, das manchetes, da reportagem e dos usuários é o que nos importa aqui. 
Beleli (2016), analisa impacto na recepção do conteúdo produzido nas redes socais e discute justamente a necessidade de tomada de posicionamento dos usuários em relação às notícias, mais especificamente feitas por movimentos sociais nas redes sociais. Em sua pesquisa, foi observado que o discurso dos usuários foi influenciado pela manchete visto que que estupradores não eram tratados como criminosos, mas a vítima era questionada por sua integridade.

Outra percepção foi sobre a mescla dos mundos online/offline que não eram o ponto crucial para analisar episódios como esse, mas sim pensar que depois da democratização da participação da comunidade não jornalística, os usuários passaram a produzir opiniões sem fundamentos causando tumulto na internet. No entanto, as consequências recaem apenas sobre o indivíduo que na verdade é vítima, e o culpado é inocentado.

Obviamente que as redes sociais propiciam um espaço amplo de debate, por isso a variedade de notícias é de praxe nos jornais em qualquer modalidade uma vez que alcançar o maior número de pessoas é o objetivo. Desse modo, qualquer postagem de notícia pode ter interação, todavia, no cenário atual, os leitores são bombardeados principalmente por notícias que envolvem política e/ou violência de forma geral, por serem assuntos mais recorrentes na plataforma. Propositalmente, claro, a construção desses discursos é feita de maneira que esse usuário não apenas role a tela do seu Facebook, mas sim pare e interaja com essa postagem. Dessa forma, "menos do que marcar a separação on/off-line, o mais interessante é refletir sobre essa interação que, a partir do on-line, cruza cenários políticos e moralidades (BELELI, 2016 p. 4).

Em se tratando de um ambiente virtual de interação social mediada por conteúdos produzidos por outros usuários, a sensação de "liberdade" é proporcionada na medida em que o leitor enxerga esse ambiente como um "mundo" separado do qual ele vive. Ele se esquece (ou finge esquecer) de que está num ambiente em que também há outras pessoas que podem ou não concordar com os seus pensamentos compartilhados na internet. Essa falsa liberdade abre espaço para todo tipo de comportamento adequado ou não dentro da plataforma e pode causar debates calorosos no Facebook. É perceptível que

Esses discursos, proferidos de maneira aberta, rápida e despreocupada têm-se tornado virais, constituindo uma espécie de tribunal de inquisição, cuja lei passa ao largo, dado que acreditam no anonimato e, portanto, na impunidade, mesmo que violem e ofendam coletividades. (BELELI, 2016, p. 10).

Acreditando na existência de uma "cortina" que separa o mundo online do off-line, esse usuário expõe aquilo que considera cabível ao ambiente virtual que, muitas das vezes, não é o mesmo fora dele. Essa separação permite a ele uma espécie de máscara na qual ocorre a sustentação de um personagem que pode 
falar aquilo que bem entende sem se importar com o impacto no outro que lê. Portanto, esse usuário entende que a internet é um ambiente permissível para todo tipo de violência.

A partir de tudo o que foi exposto sobre a relação do usuário com os conteúdos postados na plataforma, foi escolhida para esta análise a rede social Facebook. A primeira forma de interação que o usuário tem com a rede social é o visual - rolando a time line e lendo as postagens - e posteriormente ele escolhe ter ou não uma interação ativa perante elas. Uma das participações ativas são as reações, elas são "curti”, “amei”, "triste”, “uau”, "grr” e "haha”. Elas são uma forma de interação mais rápida, porém muito significativa para a recepção do conteúdo. Dentro desta rede social, serão analisadas, a seguir, as reações dos usuários nas postagens das manchetes escolhidas.

\section{Chacina de 2014}

A primeira chacina abordada é a ocorrida na noite do dia 04/11/2014, em seis bairros de Belém. Segundo noticiário publicado na página do Jornal Diário Online, o que deu início foi o assassinato do cabo da Polícia Militar, Antônio Marcos da Silva Figueiredo. Ele fora alvejado por três homens que o abordaram em frente à sua casa no bairro do Guamá. O PM estava respondendo por homicídio e por isso estava afastado do exercício de seu cargo. Após a execução, houve um forte compartilhamento de mensagens e áudios no Whatsapp, supostamente de policiais amigos do cabo, alertando sobre o "toque de recolher" que haveria naquela mesma noite a fim de localizar os criminosos. A partir da disseminação das mensagens, as execuções foram acontecendo nos bairros da Terra Firme, Marco, Guamá, Jurunas, Sideral e Tapanã. A partir desse contexto, temos, posteriormente, as manchetes selecionadas e as suas reações:

Quadro 2: Manchetes do jornal DOL sobre a chacina de 2014

\begin{tabular}{|l|l|}
\hline Manchete & \multicolumn{1}{c|}{ Título } \\
\hline M1 & "Marcha marca os 2 anos da 'Chacina de Belém'" (17/11/2016) \\
\hline M2 & "Dia de mortes reaviva memória da chacina de 2014" (20/01/2017) \\
\hline M3 & "PM miliciano é condenado a 29 anos de prisão" (22/03/2017) \\
\hline M4 & $\begin{array}{l}\text { "Familiares das vítimas de chacina de Belém ainda aguardam justiça" } \\
(09 / 12 / 2018)\end{array}$ \\
\hline
\end{tabular}

Tabela 1: Quantidade de reações às manchetes do jornal DOL sobre a chacina de 2014

\begin{tabular}{|l|l|l|l|l|l|l|l|l|l|l|l|l|}
\hline Reações & Curti & $\%$ & Amei & $\%$ & Triste & $\%$ & Uau & $\%$ & Grr & $\%$ & Haha & $\%$ \\
\hline
\end{tabular}




\begin{tabular}{|l|r|r|r|r|r|r|r|r|r|r|r|r|}
\hline M1 & 85 & $98 \%$ & 1 & $1 \%$ & 1 & $1 \%$ & 0 & $0 \%$ & 0 & $0 \%$ & 0 & $0 \%$ \\
\hline M2 & 1.655 & $88 \%$ & 8 & $0 \%$ & 141 & $7 \%$ & 57 & $3 \%$ & 15 & $1 \%$ & 13 & $1 \%$ \\
\hline M3 & 1.405 & $87 \%$ & 41 & $2 \%$ & 10 & $1 \%$ & 81 & $5 \%$ & 27 & $2 \%$ & 58 & $3 \%$ \\
\hline M4 & 97 & $87 \%$ & 0 & $0 \%$ & 8 & $7 \%$ & 0 & $0 \%$ & 0 & $0 \%$ & 6 & $6 \%$ \\
\hline Média & 810,5 & $90 \%$ & 12,5 & $0,8 \%$ & 40 & $4 \%$ & 34,5 & $2 \%$ & 10,5 & $0,8 \%$ & 19,3 & $2,5 \%$ \\
\hline
\end{tabular}

As manchetes escolhidas são dos anos 2016, 2017 e 2018 e é importante perceber o intervalo de tempo entre as postagens visto que todas são posteriores a chacina. Tendo em vista esse intervalo, todas elas funcionam como uma espécie de rememoração acerca desse episódio, o que pode ter influenciado no que diz respeito a distribuição, ao consumo e a força nas interações das postagens.

Ao analisar as reações das manchetes, percebe-se uma diferença em seu consumo dependendo do ano da postagem. Por exemplo, em 2014, não existiam todas as reações disponíveis no Facebook como na atualidade, impossibilitando, assim, a produção do discurso pelas reações. Então, o primeiro fato a se observar é a ausência de algumas dessas reações, o que pode prejudicar a força de alcance da postagem.

De acordo com a Tabela 1, pode-se perceber em relação à Manchete 1 (M1) a presença de três reações: "curti", "amei” e "triste”, porém a que mais se manifesta é a primeira. "Curti” foi a primeira reação criada pela rede social Facebook, portanto, no ano da postagem da manchete (2016), ainda era muito comum usar apenas este tipo de interação, conforme demonstram $98 \%$ das reações analisadas. No entanto, já havia usuários que gostavam de se manifestar por meio das novas reações como "amei" e "triste", ainda que resultando em menor número: $1 \%$.

É possível observar também que nas postagens das manchetes M1 e M4, nos anos de 2016 e 2018, respectivamente, ainda que no último ano citado já houvesse todas as reações, o público não teve a sua atenção capturada como nos outros anos por serem manchetes que têm um distanciamento de dois a quatro anos do ocorrido.

Considerando essa informação, percebe-se a grande diferença existente entre as manchetes M1 e M4 e as manchetes M2 e M3 (ambas de 2017), uma vez que a interação por meio da opção "curti”, vê-se reduzida para $87 \%$ e $88 \%$, respectivamente, dando espaço às outras formas de interação, como "triste", "uau" e "haha". Consideramos que o fato das reações "triste" e "uau" estarem em maiores porcentagens na M2 (7\% e 3\%, respectivamente) está relacionada ao estímulo provocado pela imagem de um cadáver anexada à manchete que aparece de forma repentina enquanto o leitor/usuário "rola" o feed de notícias. 
Já na M3, as reações "uau" e "haha" estariam em maior porcentagem (5\% e 3\%) por se tratar da notícia "PM miliciano é condenado a 29 anos de prisão". Em episódios de violência em que a polícia é autora do crime não é comum que ela seja indiciada, então esse tipo de manchete causa uma surpresa e até desconfiança, pois os autores podem não chegar, de fato, a serem punidos.

É válido pontuar que o jornal DOL não tem postagens do ano da chacina na página e isso pode ter influenciado nas reações aplicadas às manchetes escolhidas. Nesse sentido, as que obtiveram mais reações foram as do ano de 2017, provavelmente, por serem manchetes que relembram uma chacina ocorrida três anos antes (M2); e por retratar a punição dada a um policial (M3), visto que é um resultado não muito recorrente, inclusive, em chacinas.

O discurso demonstrado pelas reações à chacina de 2014, de acordo com as porcentagens das reações presentes no quadro, é de uma possível neutralidade em relação a violência. Muitos utilizaram a reação “curti”, - até mesmo quando a plataforma já tinha as demais reações, pois surgiram no ano da primeira manchete escolhida (2016) - cujo possível significado atribuído nesta pesquisa, seria de apenas ler a manchete sem esboçar empatia ou qualquer outro sentimento que expressasse solidariedade ao ocorrido. Podemos supor, também, sobre a questão da neutralidade, já que as reações eram interações novas da plataforma, o que pode ter influenciado na sua utilização diante as postagens. Logo, diante da análise feita, a violência presente na chacina de 2014 não chamou tanto a atenção dos leitores/usuários da rede social Facebook que tiverem contato com a matéria divulgada pelo jornal Diário On-line.

\section{Chacina de 2018}

A segunda chacina abordada é a do bairro do Tapanã, ocorrida na tarde do dia 29/11/2018, resultando em 10 mortes. Esse segundo episódio também teve como origem o assassinato de um policial militar, o sargento João Batista Menezes Dias, morto com inúmeros tiros na cabeça. Testemunhas contam que a chacina iniciou por volta das 18 horas e foi executada por quatro homens, em motocicletas que disparavam aleatoriamente em quem quer que estivesse no momento transitando nas vias públicas. As mortes se deram em vários pontos do bairro e a faixa etária das vítimas era de 18 a 25 anos, todos homens. Diante desse contexto, a seguir, as manchetes escolhidas e suas reações:

\section{Quadro 3: Manchetes do jornal DOL sobre a chacina de 2018}

\begin{tabular}{|l|l|}
\hline Manchete & \multicolumn{1}{c|}{ Título } \\
\hline M5 & $\begin{array}{l}\text { "Chacina no Tapanã deixa pelo menos cinco mortos com sinais de execução" } \\
(29 / 10 / 2018)(19: 00)\end{array}$ \\
\hline M6 & $\begin{array}{l}\text { "Chacina no Tapanã: vídeo mostra motoqueiros fugindo após crimes. Veja!" } \\
(29 / 10 / 2018)(21: 36)\end{array}$ \\
\hline
\end{tabular}




\begin{tabular}{|l|l|}
\hline M7 & $\begin{array}{l}\text { "Morto na chacina do Tapanã gravou vídeo sobre dar valor à vida. Veja!" } \\
(30 / 10 / 2018)(00: 11)\end{array}$ \\
\hline M8 & $\begin{array}{l}\text { "Chacina: polícia não descarta crimes terem sido praticados por milícia ou facção" } \\
(30 / 10 / 2018)(22: 52)\end{array}$ \\
\hline
\end{tabular}

Tabela 2: Quantidade de reações às manchetes do jornal Dol sobre a chacina de 2018

\begin{tabular}{|l|r|r|r|r|r|r|r|r|r|r|r|r|}
\hline Reações & Curtir & \multicolumn{1}{c}{$\%$} & Amei & $\%$ & Triste & \multicolumn{1}{c}{$\%$} & Uau & $\%$ & Grr & $\%$ & Haha & $\%$ \\
\hline M5 & 1.249 & $67 \%$ & 1 & $0 \%$ & 406 & $22 \%$ & 188 & $10 \%$ & 8 & $1 \%$ & 4 & $0 \%$ \\
\hline M6 & 1.992 & $72 \%$ & 2 & $0 \%$ & 520 & $19 \%$ & 230 & $8 \%$ & 28 & $1 \%$ & 0 & $0 \%$ \\
\hline M7 & 3.425 & $65 \%$ & 6 & $0 \%$ & 1.580 & $30 \%$ & 226 & $4 \%$ & 2 & $0 \%$ & 25 & $1 \%$ \\
\hline M8 & 718 & $85 \%$ & 1 & $0 \%$ & 97 & $12 \%$ & 18 & $2 \%$ & 6 & $1 \%$ & 2 & $0 \%$ \\
\hline Média & 1.846 & $72 \%$ & 2,5 & $0 \%$ & 650,7 & $21 \%$ & 165,5 & $6 \%$ & 11 & $1 \%$ & 7,8 & $0 \%$ \\
\hline
\end{tabular}

É importante frisar que as manchetes escolhidas são duas do dia 29/11 e duas do dia 30/11, diferenciadas apenas pelo horário. Tendo em vista as diferenças de tempo entre as postagens, isso pode ter influenciado na recepção dessas notícias. A priori, é notória a diferença na quantidade de pessoas que reagiram às postagens da chacina de 2018 em relação a de 2014, julgando pelo número das reações dos usuários. O que denota diferenças na distribuição, no consumo e na força delas.

A M5 foi publicada uma hora após a chacina no mesmo dia, logo, sendo então a primeira notícia que o usuário teve contato sobre o ocorrido. Como demonstra a Tabela 2, a reação em maior quantidade é a “curti”, apresentando intertextualidade em relação as outras chacinas. Porém, diferentemente das manchetes de 2014, essa opção ocorre em menor proporção: 67\%. Isto porque o leitor/usuário que teve acesso a essa manchete também se sensibilizou (22\% "triste") e surpreendeu ( $10 \%$ "uau”) com o acontecido.

A M6 foi a segunda manchete publicada no mesmo dia, um pouco mais de três horas, após a primeira manchete. Esta manchete se distingue das demais por ser apresentada na forma de texto acompanhada de vídeo contendo imagens de uma das execuções. A julgar pelo número de "curtidas", nota-se um aumento no número de pessoas que tiveram acesso a manchete, muito provavelmente em razão do modo como ela foi construída, o que lhe acresceu poder de consumo. Esse tipo de manchete que pede a interação do usuário tem muito mais repercussão de interação, principalmente, quando se trata de um vídeo dos causadores do crime. Sendo assim, as reações "uau" (8\%) e "triste" (19\%) demonstram que, possivelmente, este usuário assistiu ao vídeo. O que desencadeia a terceira reação mais recorrente: "grr" (1\% $=28$ usuários). 
A M7 é a primeira manchete do dia 30 de outubro. É interessante ver a repercussão dessa manchete, pois foi a que teve o maior número de reações entre as quatro postagens: 5.264 usuários. Aqui, também pode-se afirmar que o vídeo teve bastante influência em sua repercussão de modo que a manchete, além de convidar o usuário a lê-la/visualizá-la, também o sensibiliza por ser um vídeo que retrata as emoções compartilhadas por uma das vítimas. A construção das manchetes é bem parecida, bem como o seu conteúdo, o que corrobora para a intertextualidade entre elas. Portanto, as reações que mais se sobressaem são "triste" e "uau".

A M8 teve a sua publicação quase 24 horas após a M7 e isso pode influenciar a recepção dela. Ainda que tenha tido o menor número de interações, pode-se afirmar que em relação a chacina de 2014, esta teve seu início, ápice e fim em um intervalo de tempo muito curto. Todavia, ainda há de se notar que as reações mais utilizadas continuam sendo "triste" $(12 \%)$ e "uau" $(2 \%)$ e estariam demonstrando a sensibilização e surpresa em relação ao fato noticiado.

De modo geral, em comparação entre as reações às manchetes publicadas pelo Jornal Diário Online sobre a chacina de 2014, na chacina de 2018 a reação "curti” continua sendo a mais utilizada, sendo seguida pelas reações "triste" e o "uau", respectivamente, comprovando a intertextualidade entre ambas. Uma diferença em relação a chacina anterior é a grande utilização de todas as reações uma vez que os usuários já estavam familiarizados com sua utilização junto a rede social Facebook. Portanto, pode-se observar que a grande utilização do "curti” continua, porém dá lugar às outras reações as quais são determinantes para a análise desta chacina. Dito isto, constatouse que os usuários demonstraram maior inclinação para expressar a gama de sentimentos presentes nas ferramentas de interação da plataforma acerca da chacina de 2018 do que da chacina de 2014.

Estas reações também permitem conjecturar que os usuários estão mais habituados à ação das milícias nas ruas de Belém, o que pode demonstrar maior envolvimento emocional (vide porcentagem da reação "triste") deles. Uma das estratégias do jornal para atingir este objetivo foi, justamente, usar imagens e vídeos nas postagens das notícias. O aumento no número de reações (mas também o de comentários, que não foram objeto de análise neste artigo, mas constam da pesquisa que o originou) é uma evidência disso, podendo sugerir que ao lado de uma maior familiaridade com os recursos de interação da rede social os leitores/usuários das manchetes sobre a chacina de 2018 encontram-se mais sensibilizados com a violência do que na chacina anterior.

\section{Chacina de 2019}


A terceira e última chacina abordada é a do bairro do Guamá que ocorreu no dia 19/05/2019 às 15 horas. Segundo o noticiário, sete homens encapuzados invadiram o bar em três carros e uma moto disparando contra as vítimas, a maioria atingida na cabeça. Este crime resultou em 11 mortos, seis mulheres e cinco homens, e não se sabe o motivo até hoje. Primeiramente, há de se perceber que essa chacina sai do padrão no que se refere às vítimas, pois enquanto nas outras as vítimas eram sempre homens, nessa há mulheres e elas estão maior número também. À vista deste contexto, têmse as últimas manchetes escolhidas e suas reações:

Quadro 4: Manchetes do jornal DOL sobre a chacina de 2019

\begin{tabular}{|l|l|}
\hline Manchete & \multicolumn{1}{c|}{ Título } \\
\hline M9 & "Chacina no bairro do Guamá deixa 11 mortos neste domingo" (19/05/2019) (15:55) \\
\hline M10 & $\begin{array}{l}\text { "Veja o vídeo feito logo após a chacina no bairro do Guamá. Imagens chocantes!" } \\
(19 / 05 / 2019)(16: 28)\end{array}$ \\
\hline M11 & $\begin{array}{l}\text { "'Se esta ação foi para intimidar, esqueçam’, garante Helder após chacina do } \\
\text { Guamá." (19/05/2019) (22:02) }\end{array}$ \\
\hline M12 & $\begin{array}{l}\text { "Mais um PM envolvido na Chacina do Guamá é preso na madrugada deste domingo } \\
\text { (26)" (26/05/2019) }\end{array}$ \\
\hline
\end{tabular}

Tabela 3: Quantidade de reações às manchetes do jornal Dol sobre a chacina de 2019

\begin{tabular}{|l|r|r|r|r|r|r|r|r|r|r|r|r|}
\hline Reações & Curtir & $\%$ & Amei & $\%$ & Triste & $\%$ & Uau & $\%$ & Grr & $\%$ & Haha & $\%$ \\
\hline M9 & 2.258 & $47 \%$ & 9 & $0 \%$ & 1.652 & $35 \%$ & 810 & $17 \%$ & 25 & $1 \%$ & 11 & $0 \%$ \\
\hline M10 & 971 & $54 \%$ & 0 & $0 \%$ & 638 & $35 \%$ & 197 & $11 \%$ & 6 & $0 \%$ & 6 & $0 \%$ \\
\hline M11 & 1.017 & $74 \%$ & 14 & $1 \%$ & 59 & $4 \%$ & 15 & $1 \%$ & 19 & $2 \%$ & 248 & $18 \%$ \\
\hline M12 & 1.898 & $80 \%$ & 50 & $2 \%$ & 124 & $5 \%$ & 191 & $8 \%$ & 59 & $3 \%$ & 40 & $2 \%$ \\
\hline Média & $1.536,0$ & $63,8 \%$ & 18,3 & $0,8 \%$ & 618,3 & $19,8 \%$ & 303,3 & $9,3 \%$ & 27,3 & $1,5 \%$ & 76,3 & $5 \%$ \\
\hline
\end{tabular}

A M9 postada logo após a chacina, foi a que reuniu o maior número de interações, assegurandolhe ampla distribuição, consumo e força em termos de prática discursiva. As interações que mais se sobressaem são "curti", "triste" e "uau". Dentre as chacinas aqui pesquisadas, a M9 é a postagem que tem mais interações quando se trata da manchete que noticia o fato pela primeira vez, o que sugere maior familiaridade dos leitores/usuários com as ferramentas de interação da rede social e as publicações realizadas pelo jornal Diário Online. 
Quanto a M10, a segunda publicação na página sobre a postagem, percebe-se um comportamento fora do padrão. A postagem noticia um vídeo que foi filmado após a chacina. Em contraposição com a M6 da chacina de 2018 (2.772 reações), têm-se um menor número de reações em relação a M10 da chacina de 2019 (1.818 reações), mais uma intertextualidade constatada, o que pode significar menor interesse pelo veículo de transmissão da informação e, com isso, menor interesse pelo tipo de conteúdo que ele possui, qual seja, a possibilidade de visualizar o cometimento do crime.

Na manchete M11, também se nota uma similaridade com a M3 da chacina de 2014: todas as reações foram usadas de modo significativo. A M3, "PM miliciano é condenado a 29 anos de prisão", noticia um acontecimento diferente da M11, “'Se esta ação foi para intimidar, esqueçam', garante Helder após chacina do Guamá", porém desperta sensações bem parecidas. As demais emoções que mais se destacam são diferentes, enquanto na M3 a reação mais utilizada é "uau" (35\%), na M11 é "haha" (18\%). Essas reações são influenciadas pelo conteúdo de suas manchetes uma vez que a primeira aborda a notícia de uma autoridade, anteriormente mencionada, tendo sua punição cabível, e a segunda trata de uma autoridade ainda maior, o governador do estado, achando que a chacina foi feita para atacar o seu mandato. Tais reações podem conferir surpresa e ironia por parte dos usuários.

Assim como as manchetes M3 e M11, na M12 também se pode encontrar o uso de todas as reações de forma bem significativa. Embora tenha sido publicada uma semana após a chacina, o que poderia indicar uma "consolidação" do acontecido e, consequentemente, uma menor interação, essa postagem teve 2.362 reações. Assim como nas demais chacinas, essa também é uma notícia sobre a punição de um policial, apontando a intertextualidade entre elas. O diferencial é que a manchete indica que este não foi o único indiciado. Portanto, a reação mais utilizada nessa postagem depois de "curti" foi "uau".

Na chacina de 2019, a reação "curti” ainda continua sendo a mais utilizada, em seguida, temos o "triste" e o "haha", respectivamente. Esta última reação, no entanto, é a que se define como diferencial para esta última análise. Ao contrário das chacinas anteriores, houve um aumento expressivo no uso da reação "haha", mais especificamente, na M11. O que pode ter ocorrido por ser uma manchete contendo a fala de um político conhecido no nosso estado levando o usuário a reagir com ironia à postagem.

Um ponto de intertextualidade com a chacina de 2014 é a falta de credibilidade que a polícia tem ao julgar a milícia como praticante dos crimes, como pode ser percebido pela reação "haha" na 
M12. Outro aspecto interessante a ser comentado é que a chacina de 2019 é a única que contém reações de "amei" na postagem que abre as notícias sobre o acontecido. Embora não seja uma quantidade significativa, ao darmos atenção apenas para esta reação nas três chacinas, ela aparece na de 2019 e nas demais não, sugerindo uma possível mudança na percepção da violência. Desse modo, pôde-se concluir que, na chacina de 2019, os usuários estariam mais familiarizados com esse tipo de violência, chegando ao ponto de concordar com sua prática, já que o "amei” pode significar simpatia pelos assassinatos.

\section{Conclusão: bandido bom é bandido morto?}

Este trabalho teve como objetivo analisar as reações de usuários da rede social Facebook às publicações sobre chacinas ocorridas na cidade de Belém realizadas pelo jornal Diário Online (DOL) nos anos de 2014, 2018 e 2019. Por meio dele, pretendemos se esta rede social, enquanto expressão sociotécnica da interação humana, pode servir de guia ou instrumento metodológico capaz de oferecer elementos para pensar e compreender a sociabilidade observada no mundo real.

Para alcançar este objetivo, recorremos aos recursos discursivos presentes na interação dos usuários com a rede social tomando como base o modelo tridimensional presente na Análise do Discurso Crítica, por meio do qual se procurou identificar suas três categorias, quais sejam: textualidade (escrita), prática discursiva (processos de produção, distribuição e consumo dos textos) e eventos discursivos como instâncias da prática sociocultural.

Com base na aplicação deste método, chegamos à conclusão de que o Facebook pode ser considerado uma importante ferramenta para compreender a dinâmica da vida social entre aqueles que o utilizam como meio de interação com os meios de comunicação e de expressão de suas emoções com as notícias por eles veiculadas.

Assim, os dados obtidos com base na identificação e análise das reações a violência representada pelo noticiário em torno das chacinas ocorridas, permitem inferir que os usuários do Facebook se utilizam de seus ícones ou botões para expressar o que sentem em relação a este fenômeno social. Contudo, considerando que estes ícones são formas de interação cujos significados são pré-estabelecidos, não podemos definir com precisão o que cada usuário pretende expressar ao utilizá-lo. Podemos apenas demonstrar, por meio de sua quantificação e comparação, que em sua totalidade estas reações dizem "algo" sobre o comportamento social do grupo analisado. 
Em termos gerais, se pode afirmar que o uso das redes sociais como plataforma de divulgação do noticiário por jornais locais, a exemplo do Jornal Diário do Pará, se apresenta como uma importante forma de interlocução com seus usuários. Assim, para cada vez mais reduzir o público leitor do jornal impresso, esta plataforma ocupa um importante espaço de divulgação e acesso às informações sobre os eventos e a vida social local.

Quanto a interação dos usuários com as matérias publicadas sobre as chacinas ocorridas na cidade Belém, observou-se que o ícone "curti” foi o mais utilizado em todos os períodos analisados, em média $75,3 \%$. Contudo, seu uso variou negativamente $29 \%$ entre a primeira chacina analisada, ocorrida em 2014, e a última, em 2019. Este declínio se explica pelas mudanças incorporadas pela plataforma do Facebook, que a partir de 2016 incluiu novos ícones de reação, levando os usuários a se familiarizarem com novos tipos de interação com as notícias publicadas. Somada a esta mudança, o jornal Diário Online também alterou sua estratégia de divulgação das notícias, incorporando imagens e vídeos referentes às chacinas.

A familiarização com a plataforma, a inserção de novos ícones e a inclusão de imagens e vídeos nas postagens do jornal Diário online explicam, assim, a mudança nas reações às notícias sobre as chacinas ocorridas entre 2016 e 2019, conforme demonstrado pelo aumento significativo de reações "triste" (variação de 425\%) e "uau" (365\%) observado na análise dos dados.

Se considerarmos que até 2016 o ícone “curti”, era a única reação possível podendo, dentre outras coisas, sugerir que o usuário da rede social havia lido a notícia ou desejava exprimir algum sentimento em relação a ela. Com o emprego dos novos ícones, a escolha pelas reações "triste" e "uau" demonstram que o tema da chacina gera sentimentos de consternação e surpresa pelos usuários, dialogando, assim, com reações observadas em interações presenciais. Isto permite sustentar que, se a hipótese inicial apontava para uma simpatia com a expressão "bandido bom é bando morto", estes dados evidenciam um possível repúdio a sua naturalização.

Por outro lado, não se pode ignorar que, embora sejam menos representativas, as reações que indicam simpatia ("amei”), aversão ("grr”) e contentamento ("haha”) com o conteúdo da notícia, merecem atenção dos estudiosos, pois podem denunciar mudanças gradativas na percepção de usuários de redes sociais sobre as chacinas como um fenômeno social. A ênfase nestes estudos pode, desse modo, oferecer aportes metodológicos para avaliar padrões e significados socioculturais associados à reação da população à violência urbana. 


\section{Referências Bibliográficas}

ASSEMBLÉIA LEGILATIVA DO ESTADO DO PARÁ. Comissão Parlamentar de Inquérito para apuração de grupos de extermínio e milícias no estado do Pará: relatório final. Requerimento $\mathrm{n}^{\mathrm{o}}$ 310/2014, Belém, 30 de janeiro de 2015. Disponível em https://www.alepa.pa.gov.br/midias/midias/11_relatorio_final_da_comissao_parlamentar_de_inquer ito_para_apuracao_da_atuacao_de_grupos_de_exterminio_e_milicias_no_estado_do_para-testeenvio.pdf

BAKHTIN, M. M. Questões de literatura e de estética: a teoria do romance. São Paulo: Annablume, 2002.

BATISTA JR., J. R. L. Análise de discurso crítica para linguistas e não linguistas. São Paulo: Parábola, 2018.

BELELI, I. Novos cenários: entre o "estupro coletivo" e a "farsa do estupro" na sociedade em rede. Cadernos Pagu, n. 47, e164710, set./ 2016.

BRANDÃO, N. H. Introdução a análise do discurso. Campinas, SP: Editora da UNICAMP, 2004.

CASTELLS, M. A Era da Informação: Economia, Sociedade e Cultura. São Paulo: Paz e Terra, 1999.

FAIRCLOUGH, N. Critical discourse analysis: the critical study of language. Londres: Longman, 1995.

FAIRCLOUGH, N. Language and power. London: Longman, 1989.

GRAMSCI, A. Os intelectuais e a organização da cultura. São Paulo: Círculo de Leitura 1988.

LOPES, F. V; ALVES, W. Discurso e redes sociais: o caso Voz da Comunidade. Ciberlegenda, v. 1, p. 111$123,2011$.

ORLANDI, E. P. Análise de discurso: princípios e procedimentos. Campinas: Pontes, 2005.

RESENDE, V. de M. Análise de discurso crítica. São Paulo: Contexto, 2019.

REZENDE, C. B.; COELHO, M. C. Antropologia das emoções. Rio de Janeiro: Editora FGV, 2010.

SANTOS, F. C.; CYPRIANO, C. P. Redes sociais, redes de sociabilidade. Revista Brasileira de Ciências Sociais, São Paulo, v. 29, n. 85, p. 63-78, jun., 2014.

SCHIFFRIN, D. Approaches to Discourse Text. Oxford: Blackwell, 1994.

SHROEDER, R. Social theory after the Internet. UCL Press: Londres, 2018.

SIMMEL, G. "Sociabilidade, um exemplo de sociologia pura ou formal". In. MORAES FILHO, E. (org.). Georg Simmel: sociologia. São Paulo: Ática, 1983.

THOMPSON, J. B. Ideologia e cultura moderna: Teoria social crítica na era dos meios de comunicação de massa. Rio de janeiro: Vozes, 1995. 


\section{O MULTICULTURALISMO NA EDUCAÇÃO}

\section{MULTICULTURALISM IN EDUCATION}

\section{Bruno Freitas SANTOS}

Resumo: Este trabalho apresenta uma discussão sobre o universo do multiculturalismo educacional. O objetivo do presente artigo é trazer reflexões sobre a relevância do multiculturalismo na educação, cujo deveria, ser enquadrado dentro da matriz curricular, tornando a prática docente cada vez mais ampla e plural. A metodologia utilizada neste estudo, foi realizada por meio de fonte bibliográfica e as contribuições deixadas por especialistas na área, no qual desenvolveram estudos e pesquisas no campo curricular e em cultura escolar. Os resultados dessa pesquisa têm como finalidade perceber, que a educação requer inúmeras ações e intervenções para que a mesma se torne ampla, plural e completa. A conclusão deste artigo é perceber melhor o que é o universo multicultural, e toda sua amplitude, sendo o mesmo um importante requisito educacional, que deve ser trabalhado e tratado com singularidade e respeito as diferenças, que vão desde as raciais, éticas, culturais, sociais e religiosas.

Palavras chaves: Currículo, educação, Formação, Cultura.

\begin{abstract}
This work presents an discussion about the universe of educational multiculturalism. The objective of this article is to bring reflections on the relevance of multiculturalism in education, in which it must be framed within the curricular matrix, making teaching practice increasingly broad and plural. The methodology used in this study was carried out through a bibliographic source and the contributions left by specialists in the area, in which they developed studies and research in the curricular field and in school culture. The results of this research aim to realize that education requires numerous actions and interventions in order for it to become broad, plural and complete. The conclusion of this article is to better understand what the multicultural universe is, and all its breadth, being an important educational requirement, which must be worked and treated with singularity and respect for differences, ranging from racial, ethical, cultural, social and religious. The structure of this work will be in chapters and with clear and objective ideas.
\end{abstract}

Keywords: Curriculum, education, training, culture.

\footnotetext{
${ }^{1}$ Graduado em Letras (português e inglês) pela Faculdade de Tecnologia e Ciências (BA) do ano de 2006 a 2009, Pós-graduado em Literatura e Linguagem pela Faculdade Evangélica Cristo Rei (PI) no ano de 2013, Mestrando em Educação pela University Anne Sullivan, desde 2015. E-mail: bs1926019@gmail.com
} 


\section{Introdução}

Destaca-se como relevante que a educação esteja vinculada com as questões culturais de forma interdisciplinar, ou melhor, dizendo com o multiculturalismo, porque a educação também é cultura. E, isso sem sombras de dúvidas é muito importante na formação de valores éticos e sociais como: tolerância, cidadania criticidade, alta valorização da pluralidade cultural, conceitos e valores, que cada vez mais estão escassos na sociedade atual, sendo necessário que haja sempre um trabalho de exercício e de estímulo nesse sentido. Porque em partes a cultura pode se perder ou ser esquecida no decorrer dos anos.

$\mathrm{O}$ educador transformador do meio em que vive, precisa estar comprometida com a transformação de sua sociedade, de sua comunidade, e de seu núcleo de atuação. E para que isso seja possível, é necessária uma matriz curricular, que respeite de fato as diferenças e semelhanças culturais, das quais se tratando de Brasil, há uma grande riqueza a ser trabalhadas e exploradas, uma vez que o pais é miscigenado.

O multiculturalismo é uma realidade, e não pode mais ser omitido ou deixando para apenas aulas extras, ou datas comemorativas. Faz-se necessária sua implantação, como uma disciplina obrigatória com o objetivo de estimular e valorizar cada cultura e sua peculiaridades, principalmente se tratando de um país tão rico em miscigenação, como o Brasil. O termo multiculturalismo possui uma polissemia de significados. E se faz necessário conhecer e explorar toda essa polissemia.

Para Silva (2007) entende-se, que o multiculturalismo se refere aos estudos voltados para as diferentes culturas, que estão espalhadas nas cinco regiões do Brasil, cada uma com suas particularidades e especificidades. O referido autor, ainda traz a relevância da construção de uma aprendizagem, que seja multiculturalista, com o intuito de amenizar os conflitos sociais, principalmente com determinados grupos, tais como negros, índios, mulheres e outros, algo que ainda é comum e ao mesmo conflitante.

O desrespeito e a desvalorização são apresentados como problemas encontrado dentro dessa pesquisa, que é cometido contra as diferentes culturas existentes dentro do espaço escolar, seguida da desinformação acerca do funcionamento e da criação de uma matriz curricular, que contemple os aspectos que compõem o multiculturalismo. E ainda ressaltar, que a educação só será completa, quando houver o respeito mútuo ao negro, ao índio, ao homem branco, ou seja, as três culturas que constituem esse país. Os procedimentos usados para a elaboração desse trabalho é a leitura e a pesquisa, seguida do levantamento bibliográfico de autores, que estão relacionados ao tema. 
A principal justificativa pela escolha desse tema, foi construir uma nova e ampla visão, que seja muito mais abrangente, acerca do multiculturalismo dentro do currículo escolar e o seu funcionamento, bem como um novo agir docente, a partir do respeito mútuo, que necessita está contextualizado dentro do multiculturalismo e sua essência.

O referencial teórico dessa pesquisa está embasado nos estudos de pesquisadores, que trazem á tona essa importante discussão sobre currículos e culturas, no qual deixaram suas contribuições para uma aprendizagem muito mais eficiente. A coleta de dados ocorreu por meio de leitura e a releitura de obras científicas, com essa temática, sendo transcrita em ideias, que aqui foram desenvolvidas. A estrutura desse trabalho se dará por capítulos e com ideias claras e objetivas.

\section{Metodologia}

Nesta obra cientifica de cunho bibliográfico, como afirma Cervo, Bervian e Silva (2007, p.61), a pesquisa bibliográfica "constitui o procedimento básico para os estudos e pesquisas científicas". Essa fase é crucial para o desenvolvimento de uma obra cientifica, é também um ponto de partida que permite a coleta e a construção das informações que estão em pauta.

O método aqui utilizado é o bibliográfico, que tem como principal característica "explorar por

meio de diferentes autores a essência de um determinado assunto" (LAKATOS, 2007, p 107). Permitindo que fosse construído passo a passo o referencial teórico desse trabalho.

Dessa forma, foram utilizadas pesquisas referentes ao multiculturalismo, alertando para os perigos que a violência cultural pode trazer. Para tanto, foram feitas consultas em sites com artigos, que apresentavam informações pertinentes, acerca dessa temática em seus vários aspectos.

\section{Multiculturalismo e educação: Destrinchando a temática}

No cenário educacional, muito se tem discutido sobre a diversidade cultural no contexto escolar, em referência ao ensino multicultural, no qual tem ganhado muita força nos últimos anos, e pode perceber a importância do mesmo para uma educação muito mais integral e plena. Para melhor compreensão Santos, (2006) define o multiculturalismo como um reconhecimento efetivo e respeitoso das outras culturas. E tudo para ser exitoso, se começa pelo respeito, um princípio essencial na construção do processo escolar.

O multiculturalismo é uma vasta área a ser estudada e explorada no contexto escolar, no qual tem despertado o interesse de pesquisadores, teóricos, sociólogos, antropólogos e educadores, que 
tem buscado a construção de um currículo emancipatório e independente. Essa deve ser uma meta, que a educação deve alcançar, principalmente se tratando de uma educação construtivista, onde se valoriza tais princípios e valores.

Assim, é preciso entender a origem do multiculturalismo, que segundo Silva e Brandim (2008) o movimento multiculturalista se iniciou no final do século XIX nos Estados Unidos. E o interessante é que tudo isso, começou alicerçado em um problema social, que até hoje requer serias e drásticas ações e intervenções: O preconceito racial contra os negros. E de acordo com os referidos autores, os negros sempre lutaram e buscaram por direitos de igualdade e equidade, sendo que nessa época muitos dos seus direitos eram negados e desrespeitados. Como aconteceu em anos anteriores, no então Brasil colonial.

Para Silva e Brandim (2008) os precursores do multiculturalismo foram professores, doutores afro-americanos, docentes que estavam insatisfeitos e revoltados com o nível de preconceito e de exclusão, que vinha há anos sendo cometidas contra os negros. O que, infelizmente até os dias atuais, ainda acontece de forma mascarada ou escancarada. De acordo com os referidos autores eram priorizadas também as questões sociais, políticas e culturais de interesse do homem negro. E, essa luta trouxe de nobre a valorização do homem negro, frente a uma sociedade discriminatória e exclusivista. Como se tem visto até os dias atuais, só que hoje de forma camuflada.

$\mathrm{Na}$ visão de Moreira é ressaltado, que a sociedade é multicultural, dessa forma a escola também deve ser multicultural:

"Numa sociedade que se percebe cada vez mais multicultural, cuja "pluralidade de culturas, etnias, religiões, visões de mundo e outras dimensões das identidades infiltra-se, cada vez mais, nos diversos campos da vida contemporânea." (MOREIRA, 2001, p. 41).

De acordo com o autor é de fácil percepção, enxergar toda essa pluralidade de culturas, etnias, religiões, diferentes visões de mundo, múltiplas identidades dentro da escola e fora dela. Todos esses pontos são minuciosos e decisivos na construção do conhecimento científico. Nesse sentido é necessário valorizar os saberes gerais, particulares e locais de cada região e de cada escola. E nunca cometer ou estimular a violência cultural contra o sujeito, pois o que deve prevalecer dentro do espaço escolar é a tolerância e o respeito às diferenças do outro, independentemente da cor de pele, da condição social ou do credo religiosos.

Como confirma Silva e Bradim (2008) o multiculturalismo, visa respeitar e levantar a bandeira da pluralidade de identidades culturais, a heterogeneidade. Em sua fala ainda acrescenta que, é 
necessária uma construção harmônica das relações sociais entre os indivíduos em meio as suas muitas diferenças, algo que é desafiador e ao mesmo tempo necessário. È necessário, que aconteça a convivência pacifica e tolerante entre os indivíduos, mesmo reconhecendo que a sociedade em sua grande maioria age e se comporta de forma discriminatória, preconceituosa ou excludente. Porque a visão do homem está voltada ao capitalismo, o que torna o homem preconceituoso e inclinado a exercer as diferentes formas de exclusão.

Estabelecer uma educação multicultural, significa romper com as rupturas e os modelos estabelecidos pela educação tradicional europeia, modificando o velho e batido currículo escolar, que se tem hoje. Nesse sentido é dado a abertura para a implantação de um novo currículo com muito mais abrangência, transformado de fato o conhecimento em significados úteis para a vida social, fora do ambiente escolar, o que tornaria a aprendizagem muito mais significativa.

De acordo com Moreira (2001), a educação multicultural requer inicialmente um pensamento abrangente sobre o que é uma educação multicultural, isso nos leva a questionar se o professor em exercício de sua profissão, tem ou não uma visão pluralista sobre educação e cultura ou cultura e educação.

Para esse autor a primeira mudança dentro da educação multicultural, deve partir da figura principal do processo de ensino aprendizagem: O professor. Ele é o instrumento humano de formação e construção de opiniões, se ele está fora do contexto de uma educação multicultural, seu trabalho não será produtivo. A partir dessa fundamentação, observa-se que é necessário à qualificação inicial e continuada de cursos para que, essa prática docente seja, cada vez mais aperfeiçoada e produtiva. Porque ainda existe, muito o perfil de profissionais ultrapassados e que, não se adequaram às necessidades dessa nova forma de educar e de construir saberes.

A escola de hoje, precisa de várias reformulações, desde as mais simples até as mais complexas, principalmente se tratando de multiculturalismo escolar. Faz se necessário, apagar do currículo certo saberes, que não irão estimular uma reflexão crítica do aluno. Valorizando no seu cotidiano as práticas pertencentes à cultura e a sua diversidade, onde poderão ser inseridos a igualdade de gêneros, a resiliência, a solidariedade e o respeito mútuo. Focos esses, que cada vez mais precisam ser trabalhados e explorados.

Na visão dos autores Mclaren e Giroux (2000, p.26), a educação multicultural deve propor uma: "a formação precisa desenvolver nos sujeitos a capacidade de questionar os conhecimentos e práticas legitimadas provendo-os contra discursos". 
Essa teoria afirma que, uma educação multicultural é aquela que tem o objetivo de desenvolver nos indivíduos uma excelência no nível de capacidade, de questionamento, de tomada de decisões e resolução de problemas. Quando o indivíduo consegue atingir um bom nível de criticidade e de questionamento, ele consegue fluir melhor com os conhecimentos construídos, durante os anos de escolarização, aplicando-os melhor na vida prática.

Investir de maneira enfática, numa formação pedagógica multiculturalmente é imprescindível. Numa formação pedagógica a partir da perspectiva multicultural é a chave para que a educação dê um salto em qualidade. Uma vez que, ao se priorizar esse tipo de educação, em concordância com as políticas educacionais, que comtemplem a educação multipluralizada, funcionam com maior eficácia, e com objetivos maiores, que sejam de fatos alcançados.

Adotar as políticas multiculturais, dentro da educação é uma grande cartada, na qual deu muito certo como, por exemplo, nos Estados Unidos, Canadá, Portugal entre outros países a cultura é valorizada sob o princípio do respeito e da tolerância. No Brasil essas políticas multiculturais é algo ainda muito recente, no qual tem sido incorporado pouco a pouco na matriz curricular, e isso tem sido muito benéfico para uma educação muito mais ampla e significativa.

O termo multiculturalismo é uma expressão muito abrangente, no qual incluem diferentes definições e perspectivas, dependendo da visão dos autores e pesquisadores. Todavia, todas essas visões são muito pertinentes e válidas.

Para o autor Hall, o multiculturalismo é definido como:

O termo multiculturalismo é substantivo. Refere-se às estratégias e políticas adotadas para governar ou administrar problemas de diversidade e multiplicidade gerados pelas sociedades multiculturais. É usualmente utilizado no singular, significando a filosofia específica ou a doutrina que sustenta as estratégias multiculturais. (HALL, 2006, p. 50)

Para esse autor o multiculturalismo é uma política educacional, que tem o objetivo de administrar as questões multiculturais de uma determinada sociedade. Tratando-se de Brasil o multiculturalismo é mais do que obrigatório, não só como um tema transversal, mais como uma área especifica do conhecimento, que deve ser trabalhado com cautela e objetividade, construindo o respeito mútuo e a alta valorização da cultura, já que o Brasil é um país multicultural.

O significado do multiculturalismo é muito abrangente, o autor acima ressalta, que o multiculturalismo é uma estratégia, que sustenta uma doutrina filosófica multicultural. Esse tipo de estratégia deve ser enquadrado dentro do contexto escolar, com o intuito de transformar a educação 
em um ensino muito mais democrático e diverso, respeitando toda essa riqueza cultural que existe, usando como um recurso útil para melhor contextualizar o processo de ensino aprendizagem.

Lidar socialmente com uma sociedade multicultural é cada vez mais desafiador, porque a situação de conflitos culturais é sempre presentes nas relações humanas, e toda essa problemática deve ser previamente trabalhada com sabedoria, evitando a violência cultural, algo muito comum na sociedade atual, devido as diferenças de classes sociais, outro grave problema, que reflete na educação.

O multiculturalismo pode ser visto, por diferentes óticas. De acordo com o autor Silva (2007) pode ser entendido como uma relação de poder, ao afirmar que "o multiculturalismo não pode ser separado das relações humanas, antes de qualquer coisa, obrigam essas diferentes culturas raciais, étnicas e nacionais a viverem no mesmo espaço". (SILVA, 2007, p. 85)

Nesse pensamento, o multiculturalismo é uma área indissociável das relações humanas, porque as ações humanas são regidas pela cultura, desde a linguagem até as diferentes formas de aprendizagens, tudo é refletido pelo grau de cultura, que desde o nascimento dos indivíduos, estão entrelaçados em todos os aspectos da maneira de viver, de falar, de se vestir, e em cada comportamento de cada sujeito.

Segundo Canen e Oliveira, a definição para o multiculturalismo é:

O multiculturalismo é um termo polissêmico que engloba desde visões mais liberais ou folclóricas, que tratam da valorização da pluralidade cultural, até visões mais críticas, cujo foco é o questionamento a racismos, sexismos e preconceitos de forma geral, buscando perspectivas transformadoras nos espaços culturais, sociais e organizacionais. (CANEN \& OLIVEIRA, p.26, 2002).

De acordo com esses autores, o termo multiculturalismo é conceituado de uma forma bem clara, consiste no englobamento de diferentes visões, seja ela liberal ou folclórica. O objetivo final do multiculturalismo é propor um questionamento pessoal nos indivíduos, que serve de subsídio para combater o racismo e o preconceito. Dois pontos alvos, que devem ser sabiamente trabalhados, já que a sociedade em que o homem está inserido é tão preconceituosa, excludente e racista.

Por fim, o propósito do multiculturalismo é a busca de novas perspectivas, que sejam transformadoras nos espaços culturais, sociais e organizacionais, incluindo a escola. É essa mudança, que é necessária para uma educação significativa, e essa tão sonhada mudança é fruto de uma educação multicultural. Como nos confirma Pansini; Nenevé (2012), em uma das suas obras intitulada Educação Multicultural e Formação, onde tudo isso é tratando com tanta clareza e profundidade. 
Analisando a ótica do autor Mclaren, o multiculturalismo crítico é aquele que "o multiculturalismo crítico sustenta que a diversidade deve ser assegurada dentro de uma política crítica e compromisso com a justiça social” (MCLAREN, 1997, p. 123).

Nessa teoria o multiculturalismo crítico tem o poder de provocar mudanças nas relações sociais, culturais e institucionais. E dentro dessas mudanças é possível mudar o contexto cultural escolar e estabelecer um respeito à diversidade cultural, desde muito cedo, e preferencialmente na primeira infância. Essa ação está enquadrada dentro das políticas públicas e críticas, cumprindo uma meta ainda maior, que o cumprimento da justiça social, na qual está inserida dentro da cidadania.

De acordo com o pensamento de Oliveira e Miranda, a educação multicultural é aquela que "a educação multicultural lida diretamente com as diferenças e com as resistências e se compromete com o questionamento das desigualdades sociais" (OLIVEIRA; MIRANDA, 2004, p. 4).

A partir dessa afirmação, percebe-se que o espaço para a educação multicultural é muito mais significativo, do que aquilo, que se imagina, porque abre espaço para uma ação docente, na qual irá trabalhar com as diferenças culturais, de gênero, de classes sociais, econômicas e religiosas. Pontos chaves para uma educação igualitária, onde os princípios e valores sejam de fato respeitados e praticados dentro dessa sociedade, combatendo as inúmeras desigualdades sociais.

Na visão de Moreira (2001) é preciso "que haja professores capazes de uma ação pedagógica multiculturalmente orientada" (p. 43). A preocupação do autor aqui é a falta de profissionais, que exerçam essa função multicultural. Um grave problema na construção de uma educação multicultural é a ausência desse educador, capaz de desenvolver sua ação pedagógica, dentro dessa necessidade e dessa nova realidade. É a partir desse problema, que a União, Estado e Municípios comprometidos com uma educação multicultural, devem ofertar cursos de formação inicial e continuada, para que ocorra essa construção multicultural, dentro da ação docente, que ocorre dentro das salas de aula.

Quando houver uma postura multicultural, por parte de professores e alunos, isso refletirá em toda sociedade, e pouco a pouco ocorrerá mudanças significativas que serão benéficas, mesmo reconhecendo que todo esse trabalho, não é uma tarefa nada fácil.

Ainda na visão de Moreira e Candau, a formação multicultural propicia "a formação multicultural deve ajudar os professores a desenvolverem uma nova identidade, uma nova postura, assim como novos saberes, novos objetivos, novos conteúdos, novas estratégias e novas formas de avaliação" (MOREIRA; CANDAU 2003, p. 157).

Neste sentido é revelado o poder de transformação, que a formação multicultural deve proporcionar dentro da ação pedagógica. Em primeiro lugar desenvolve uma nova identidade; Em 
segundo lugar, desenvolve uma nova postura; Em terceiro lugar são construídos novos saberes, objetivos, conteúdos, estratégias. Fundamentado nesses benefícios, haverá uma educação muito mais inovadora e de maior alcance.

Essa reformulação, deve acontecer principalmente no currículo, depois na sua prática docente. Quando ocorrer essas duas primeiras mudanças, estaremos construindo uma educação de fato multicultural.

De acordo com Moacir Gadotti enfatiza, que a educação multicultural, funciona como "a educação multicultural vem em auxílio do professor para melhor desempenhar sua tarefa de falar ao aluno concreto Ela valoriza a perspectiva do aluno, abrindo o sistema escolar e construindo um currículo mais próximo da sua realidade cultural" (GADOTTI, 1992, p. 4).

Ao analisar a educação multicultural, é possível perceber, que ela serve de auxiliar no processo de aprimoramento e no bom desempenho do professor com os seus alunos, inclusive sua linguagem. Por fim, proporciona um currículo mais próximo da sua realidade, onde esse aluno pode intervir por meio de sua ação, transformando o meio em que ele está inserido, de forma positiva.

$\mathrm{Na}$ visão de Moreira e silva o currículo deve enfatizar “o currículo deve enfatizar a importância de tornar o social, o cultural, o político e o econômico os principais aspectos de análise e avaliação da escolarização" (MOREIRA; SILVA, 2005, p:19).

Nesse contexto, a vida escolar estar intimamente relacionada com os requisitos sociais, culturais, políticos e econômicos, e isso é uma verdade absoluta. Na prática isso, representa que a educação multicultural, não é um sistema unitário ou monolítico, pelo contrário é um processo em coletividade, que acontece em concordância com outras importantes ações. Nesse sentido, surge a enorme necessidade de uma reformulação de toda a matriz curricular, que se tem hoje, para atender essa tamanha necessidade de uma educação multicultural, que abranja os aspectos sociais, culturais, políticos e econômicos de toda uma sociedade, a começar pelo PPP da escola, um documento oficial, que pode ser usando como um recurso multicultural.

A educação é um processo, que em sua essência deve acontecer, sem nenhum tipo de discriminação, mesmo reconhecendo, que é uma tarefa desafiador e difícil. É necessário quebrar muitos preconceitos, muitos tabus e muitos estereótipos, que foram sendo construídos ao longo dos anos pela sociedade, e que até hoje prevalecem com tanta força. Preconceitos, exclusão, rejeição e discriminação, que são enraizados nas pessoas, desde o seu nascimento e que vem se perpetuando de geração em geração, precisam ser combatidos com eficácia. 
A educação multicultural é uma exigência e ao mesmo tempo uma necessidade, assistida pela lei, mas carece de ser mais e mais posta em prática. Lamentavelmente, isso pouco tem sido levado a sério, mas é preciso abrir espaços para as mudanças. Mudanças essas, que nascem a partir da implantação de políticas públicas educacionais, de programas e de projetos educacionais, que abranjam com maior amplitude a educação multicultural com toda a sua riqueza de diversidade.

A escola independente, de onde ela esteja localizada se é no campo, na cidade, na periferia ou no melhor bairro da melhor da capital deve seguir sempre a linha do respeito e da pluralidade cultural, o que é proposto também na reformulação da nova BNCC. E, nesse sentido Menezes (2012) explica, que a escola é um espaço de disseminação e de construções, podendo ser um instrumento pedagógico de prevenção e diminuição do preconceito nas suas mais diversas facetas. Que se tratando em nossa sociedade ele aparece com diferentes nomenclaturas, deixando cicatrizes profundas em toda a sociedade.

A escola sombras de dúvidas, é um relevante sistema aberto que é composto por diversas instituições como: a igreja, família, meios de comunicação e tantos outros. Assim, surge a necessidade de se exercitar a tolerância e o respeito dentro desse tão rico universo multicultural, que é a escola. Que nada mais é do que uma mistura de diferentes classes sociais, costumes, aspectos físicos e culturais de um determinado povo, ou melhor dizendo de diferentes povos.

Menezes (2012) termina sua fala acrescentado, que o espaço escolar com a sua importante função social, que exerce deve priorizar em todas as instâncias a preservação da diversidade cultural, mantendo a mesma viva com seus valores, princípios e ideologias. Porque segundo o autor, ela é total responsável pela promoção da equidade. E é a conquista da equidade social, que fará de todos uma sociedade mais justa e feliz. Onde haverá maiores possibilidades, que todos usufruam dos seus direitos e serviços básicos como cidadão, que são. Por último Menezes (2012), exorta que o preconceito seja ele o racial, o cultural ou o religioso, ou o social cria uma ação perversa e dolorosos. Assim, a educação requer que, haja uma educação cada vez mais humanizadora, onde seja exercitado o respeito, a resiliência pela a identidade cultural do outro.

\section{Considerações Finais}

A escola é uma instituição social, com grande riqueza de multiplicidades e diferenças culturais, sociais, econômicas, étnicas e religiosas, que devem ser trabalhadas dentro desse currículo escolar, no qual se encontra tão deficiente, onde requer sérias reformulações. 
A valorização de uma identidade cultural, deve ser respeitada e preservada, principalmente se tratando da construção dos valores e princípios da cidadania. O papel fundamental da arte do educar é propiciar uma vida harmônica, mesmo em meio a tantas diferenças, conflitos e desigualdades.

Educar de forma multicultural, é construir sujeitos cada vez mais humanos e sensíveis a ele mesmo e aos outros. Já que, certos princípios foram se perdendo ao longo dos tempos, ou não se tem dado a real importância para eles na sociedade contemporânea. Quando é desenvolvido desde muito cedo determinados princípios e valores, as crianças aprendem a ser mais respeitosas culturalmente, e no futuro teremos um adolescente, um jovem e um adulto muito mais comprometido e consciente do seu papel, enquanto cidadão e cidadã.

Essa adaptação de uma nova educação multicultural, deve ser processual, respeitando o tempo necessário para aderir tantas mudanças. Esse tipo de educação deve propiciar fortes mudanças, e para isso o currículo escolar, deve ser flexível a essas mudanças. E isso requer, tempo, comprometimento, amadurecimento e ações interventoras e emergenciais de todos que constroem e fazem a educação de fato fluir e acontecer.

As políticas públicas educacionais, devem combater os diferentes tipos de preconceitos, existente na sociedade atual, um grave problema que, serve de obstáculo para o êxito da educação multicultural em muitos aspectos.

O currículo escolar, só terá um novo sentido e um novo significado quando, o mesmo for de fato produtivo, e reformulado visando não só um pequeno grupo e sim a coletividade. O que se nota, que a educação de qualidade é privilégio para poucos, e existe um número significativo de pessoas as margens da exclusão social.

Deste modo a educação deve ser a primeira prioridade e a primeira preocupação para todas as esferas administrativas de uma sociedade. Quando ocorrer tais mudanças, haverá novos efeitos. E estes efeitos ajudaram de forma significativa a construir seres humanos cada vez melhores consigo mesmo e com os outros.

Por último, em resposta ao objetivo inicial e a situação problema aqui proposta, conclui-se que o objetivo foi atingido, pois a partir dessa discussão foi possível refletir sobre a temática, desconstruindo visões preconceituosas, acerca das demais culturas existentes, reconhecendo que é necessário estabelecer parcerias em prol de uma educação mais inclusiva e menos exclusivista. Como sugestão, indica-se que novos estudos, sejam realizados dentro dessa importante temática, para que sejam aprofundados outros aspectos que estão contextualizados com a temática. 


\section{Referências}

CANEN, A. O multiculturalismo e seus dilemas: implicações na educação. Revista comunicação e política, $\quad$ v.25, n.2, p.091-107, 2007. Disponível em: http://www.cebela.org.br/imagens/Materia/02DED04\%20Ana\%20Caren.pdf. Acesso em: 02 mar. 2019.

CANEN, Ana; OLIVEIRA, Ângela Maria A. de. Multiculturalismo e currículo em ação: um estudo de caso. 2002 Disponível em: <http://www.anped.org.br/reunioes/25/anacanent12.rtf> Acesso em 7 jul. 2018.

CERVO, A. L.; BERVIAN, P. A.; SILVA, R. Metodologia científica. 6. ed. São Paulo: Pearson Prentice Hall, 2007.

HALL, Stuart. A questão multicultural. In. SOVIK, Liv (Org.). Da diáspora: Identidade e mediações culturais: Belo Horizonte: UFMG, 2006.

LAKATOS, Eva Maria; MARCONI, Marina de Andrade. Fundamentos de metodologia científica. 5.ed. São Paulo: Atlas, 2003.

MENEZES, Waléria. O Preconceito Racial e suas Repercussões na Instituição Escola. maringa.odiario.com/.../o-preconceito-racial-e-suas-repercussoes-na-. (Acessado em 05/2018).

MCLAREN, P. E GIROUX, H. Escrevendo das margens: geografias de identidade, pedagogia e poder. In: Mclaren, $P$. Multiculturalismo revolucionário: pedagogia do dissenso para o novo milênio. Porto Alegre: ed. ArtMed, p. 25-50. (2000).

MOREIRA, A. F. B. Currículo, cultura e formação de professores. Revista Educar, Curitiba, Editora da UFPR, n. 17, p. 39-52. Moreira, A. F. B. e Candau, V. M. (2003). Educação escolar e cultura(s): construindo caminhos. Revista Brasileira de Educação. no. 23. Rio de Janeiro, Mar/Ago, p. 156-168. (2001).

MOREIRA, A. F. B. e Silva, T. T. da. (orgs.). Currículo, Cultura e Sociedade. São Paulo: Cortez. Oliveira, O. V. de \& Miranda, C. Multiculturalismo crítico, relações raciais e política curricular: a questão do hibridismo na Escola Sara. Revista Brasileira de Educação. n. 25, Jan./Abr, p. 67- (2005).

PANSINI, Flávia, NENEVÉ, Miguel. Educação Multicultural e Formação Docente.www.curriculosemfronteiras.org/vol8iss1article/pansini_neneve.pdf. (Acessado em 04/2018). 
SANTOS, José Luiz dos, 1949. O que é cultura. São Paulo: Brasiliense, 2006. (Coleção primeiros passos; 110)

SILVA, T. T. da. Documentos de identidade: uma introdução às teorias do currículo. 2 ed. Belo Horizonte: Autêntica. Simon, R. I. A Pedagogia como uma tecnologia cultural. In: SILVA, T. T. da. (org.) Alienígenas na sala de aula: uma introdução aos estudos culturais em educação. Petrópolis, RJ: Vozes, p. 61-84. (2005).

SILVA. Maria José Albuquerque. BRANDIM, Maria Rejane Lima. Multiculturalismo e educação: em defesa da diversidade cultural. versão: ano I - no I: pp. 56-61, jan./jun, 2008. Disponível em: http://www.ufpi.br/subsiteFiles/parnaiba/arquivos/files/rd-ed1ano1-artigo4_mariasilva.pdf.

Acessado em 13 de nov. de 2019. 
http://dx.doi.org/10.18542/rmi.v14i22.9648

\title{
DINÂMICA ESPACIAL DE USO E OCUPAÇÃO DO SOLO URBANO NO MUNICÍPIO DE BREU BRANCO-PA
}

\section{SPATIAL DYNAMICS OF USE AND OCCUPATION OF URBAN SOIL IN THE MUNICIPALITY OF BREU BRANCO-PA}

\author{
Wagner Luiz Gonçalves da SILVA ${ }^{1}$ \\ Instituto Federal do Pará \\ Gilberto de Miranda ROCHA ${ }^{2}$ \\ Universidade Federal do Pará
}

\begin{abstract}
Resumo: Breu Branco é um município do estado do Pará, localizado na microrregião do lago de Tucuruí. Ao longo dos anos o município experimentou um crescimento populacional acelerado, consequência da migração de pessoas oriundas de outras regiões em busca de trabalho e moradia próximos às obras de barragem. $O$ crescimento espacial tem forte relação com a Hidroelétrica. Além do fator populacional, outros três fatores foram importantes para o crescimento espacial de Breu Branco: o preço da terra, a topografia da área de expansão e a falta de políticas de proteção ambiental no município. Nesse trabalho utilizamos ferramentas cartográficas e sensoriamento remoto para a construção de mapas em três períodos 1996, 2006 e 2016. Os resultados obtidos mostram novas dinâmicas espaciais, como a duplicação da área urbana, saturação do núcleo projetado da cidade em direção ao norte, conversão de áreas de floresta e preservação (APP) em ocupações, concentração imobiliária e especulação sobre novas áreas, do ponto de vista populacional um aumento de $58 \%$ da população em vinte anos.
\end{abstract}

Palavras-chave: Hidroelétrica. Território, Dinâmicas de uso e ocupação do solo. Cartografia. Plano diretor.

\begin{abstract}
Breu Branco is a municipality in the state of Pará, located in the microregion of Lake Tucuruí. Over the years, the municipality experienced an accelerated population growth, a consequence of the migration of people from other municipalities of Pará and the northeast region of Brazil in search of work and housing near the works. The spatial growth has a strong relationship with the implementation phases of the Tucurui HPP. In addition to the population factor, three other factors were important for the Breu Branco spatial growth: the price of land, the topography of the expansion area and the lack of environmental protection policies the municipality. In this work, we used cartographic tools and remote sensing for the construction of maps in three periods 1996, 2006 and 2016. The results obtained show new spatial dynamics, such as the duplication of the urban area, saturation of the projected nucleus of the city towards the north, conversion of forest and preservation areas (APP) into occupations, real estate concentration and speculation about new areas, from the point of view. population view an increase of $58 \%$ of the population in twenty years.
\end{abstract}

Keywords: Hydroelectric.Territory. Dynamics of use and Soil occupation. Cartography. Master Plan.

\footnotetext{
${ }^{1}$ Msc. em Gestão de Recursos Naturais e Desenvolvimento Local (UFPA). Professor do Instituto Federal do Pará (IFPA). E-mail: wagner.goncalves@ifpa.edu.br

${ }^{2}$ Dr. em Geografia, (USP). Pós-doutor em Ordenamento Territorial (Universite Paris 13NORD). Professor do Programa de Pós - Graduação em Gestão de Recursos Naturais e Desenvolvimento Local na Amazônia (UFPA). E-mail: gilrocha29@gmail.com
} 


\section{Introdução}

A Amazônia foi uma região prioritária para a integração nacional nos anos 1965-1985 (BECKER, 2009). A ação do estado nesse período esteve voltada à lógica da formação da malha territorial, tanto técnica, quanto política para produção do espaço, de construir o território e posteriormente produzir um espaço político.

No século passado, várias estratégias de gestão do espaço foram implantadas na Amazônia, o ordenamento territorial foi pautado em programas governamentais de acesso a terra, muito discutido, se foram estratégias positivas ou não de ocupação, mas o fato é que impulsionaram a colonização da região sob a égide da integração, que favoreceu o assentamento de pessoas teoricamente "sem terras" vindas de outras regiões do país, para um vazio demográfico que era a região amazônica (BECKER,1998). No contexto do sudeste paraense a implantação de projetos mineradores e de beneficiamento de alumínio, demandava estabilidade no suprimento de energia. Segundo Locatelli (2009), o macroplanejamento na década de 70, por exemplo, tinha como meta, desenvolver regiões atrasadas através da implantação de polos de crescimento econômico. A lógica desenvolvimentista desse período incentivou a distribuição de terras, implantação de projetos de mineração, agropecuária e produção energética, o que subsidiou a construção da Usina Hidroelétrica de Tucuruí (UHE Tucuruí), projetada com a finalidade, sobretudo, de subsidiar a energia necessária aos projetos de exploração mineral nos Estados do Pará e Maranhão. A execução das obras para sua implantação condicionou uma mudança na paisagem da região sudeste do Pará, impulsionando a formação de cidades como Tucuruí e Breu Branco.

Segundo a Organização das Nações Unidas (ONU), nos países em desenvolvimento, vivem 2,9 bilhões de pessoas. A maioria das populações desses países vive em áreas urbanas e demandam serviços diversos como infraestrutura, saúde, manejo de resíduos sólidos e consumo de energia. Em relação a este último item, em especial, a matriz energética tem forte contribuição das usinas hidroelétricas, a exemplo de Brasil e China. A construção dessas usinas ocorre para atender a "mega projetos" de investimento de capital, além da demanda de consumo por energia elétrica (FEARNSIDE, 2015). Porém, a implantação de hidroelétricas, muda o contexto do meio ambiente local e a dinâmica de ocupação do espaço no entorno desses empreendimentos. No caso do município de Breu Branco, no estado do Pará, os impactos ambientais por conta da barragem, deslocaram compulsoriamente a população afetada principalmente a jusante (Rocha, 2016), que após o alagamento de seu território, foram realocadas nas áreas do entorno das obras, que somados ao 
contingente de trabalhadores diretos e indiretos contratados para as atividades de construção, mais tarde vieram a compor a grande maioria da população do atual município de Breu Branco.

Conforme o pensamento de Raffestin (1993), a produção do território é feita a partir do espaço e por meio do uso do território pela sociedade, sendo produto das relações exercidas pelos usuários sobre determinado espaço. As cidades apresentam diversas relações sociais que produzem territorialidades diversas dentro do contexto urbano, essas diferenças são explicadas pelo histórico de formação da população das cidades no Brasil, principalmente após a década de 50, através dos fluxos rural-urbano, nos quais as pessoas buscavam oportunidades de emprego e qualidade de vida nas zonas industriais, o que resultou no crescimento das principais cidades brasileiras (MARTINS, 2012).

A construção da Usina Hidroelétrica de Tucuruí (UHE Tucuruí) atraiu mão de obra de diversas regiões para o contexto breuense. Para Rocha (2005), houve um efeito polarizador no entorno da UHE, que transformou o padrão de ocupação regional, reorganizando o espaço anterior, já que ao se implantar a usina, alteraram-se os padrões históricos de localização das atividades. É esse contexto de dinamismo populacional, territorial e ambiental em que se concentram as discussões desse trabalho, no intuito de mostrar as mudanças no contingente populacional e espacial provocadas pela implantação da usina. Esse crescimento significativo criou um cenário diferente do contexto inicial projetado para o município de Breu Branco. Se o contingente populacional extrapolou em poucos anos as ofertas de habitação e espaços regularizados na sede e seu entorno, qual o impacto espacial a ocupação dos vazios urbanos trouxe para a conjuntura atual da área urbana do município? Quais fatores, além do contingente populacional contribuíram para a ocupação de novas áreas? Quais estratégias o poder público municipal deve adotar para ordenar o território sob a perspectiva da sustentabilidade?

\section{Metodologia}

A construção do trabalho se deu com base em dados coletados através de pesquisa bibliográfica, entrevistas e dados de satélite. As entrevistas ocorreram entre julho e outubro de 2018, buscando informações junto à prefeitura municipal, especificamente às secretarias de obras e meio ambiente, e associações de moradores de bairro. O objetivo foi coletar dados de malha territorial como; mapas, plantas topográficas, memorial descritivo, informações da origem do município e como se deu a ocupação dos bairros mais recentes como Liberdade, Japonês e Santa Catarina. As entrevistas foram coletadas na forma de áudio, informalmente, nos quais ouvimos moradores, secretários 
municipais e representantes de sindicatos. No momento da pesquisa o município passava por conflitos administrativos, por tanto optamos por conversas gravadas em áudio, segundo Gil (1999), a entrevista informal é o menos estruturado possível e só se distingue da simples conversação porque tem como objetivo básico a coleta de dados.

O outro braço metodológico consiste no uso de dados cartográficos. O município de Breu Branco dispõe de poucas informações espaciais, assim toda base de dados cartográfica do presente trabalho, provém de fonte pública, como do Instituto Nacional de Pesquisas Espaciais (INPE) e Secretaria de Estados e Meio Ambiente do Pará (SEMA). Esses dados foram posteriormente processados em ambiente computacional, no âmbito do Laboratório de Cartografia no Núcleo de Meio Ambiente da Universidade Federal do Pará (UFPA). Utilizamos classificação supervisionada em imagens do Satélite Cino - Brasileiro (CBERS), para produzir os mapas de uso e ocupação do solo, referente a 1996, 2006 e 2016. Segundo Xavier e Bastos (2010), fora do campo da modelagem e simulação de cenários futuros, os dados espaciais podem ser estudados através da integração e interpretação de dados da evolução temporal da mancha urbana, critério usado para análise das dinâmicas espaciais desse trabalho.

\section{Dinâmica populacional}

Segundo o Instituto Brasileiro Geografia e Estatística - IBGE, Breu Branco em 2016 possuía uma população de aproximadamente 64.000 habitantes. A ênfase no contexto populacional no município é relevante em função de ser uma cidade localizada na área de influência direta da UHETucuruí. Segundo Rocha (2016), entre 2000 e 2007, Breu Branco apresentou um ritmo de crescimento "galopante" em relação a municípios como Goianésia e Novo Repartimento, que estão na microrregião região do lago de Tucuruí, porém mais afastados da área de construção da barragem. $\mathrm{O}$ crescimento foi da ordem de $4,7 \%$, superior ao ritmo de crescimento do estado do Pará, que segundo Rocha et al (2016) era de 1,67\% no mesmo período. Com base nos números de crescimento dos últimos anos, estimamos que a população cresceu a uma taxa de incremento de aproximadamente 1.850 habitantes por ano. As primeiras fases das obras da hidroelétrica iniciaram oficialmente em 1975 e estenderam-se até 1992, tendo uma pausa e retomando a segunda fase em 1998, seguindo até 2010. No recorte de pesquisa, os dados referentes ao período entre 1996 e 2010, apresentam números populacionais saindo de pouco mais de 20.000 habitantes para mais de 50.000 habitantes (Figura 1). O percentual de crescimento populacional foi da ordem de $58 \%$ de aumento, e o período 2010 e 2016 , teve aproximadamente $23 \%$ de aumento populacional. 
O crescimento rápido está diretamente relacionado à implantação da hidroelétrica. A evolução populacional após o termino das obras da barragem, teve um percentual menor de crescimento.

Figura 1 - Evolução populacional no período 1996 a 2016

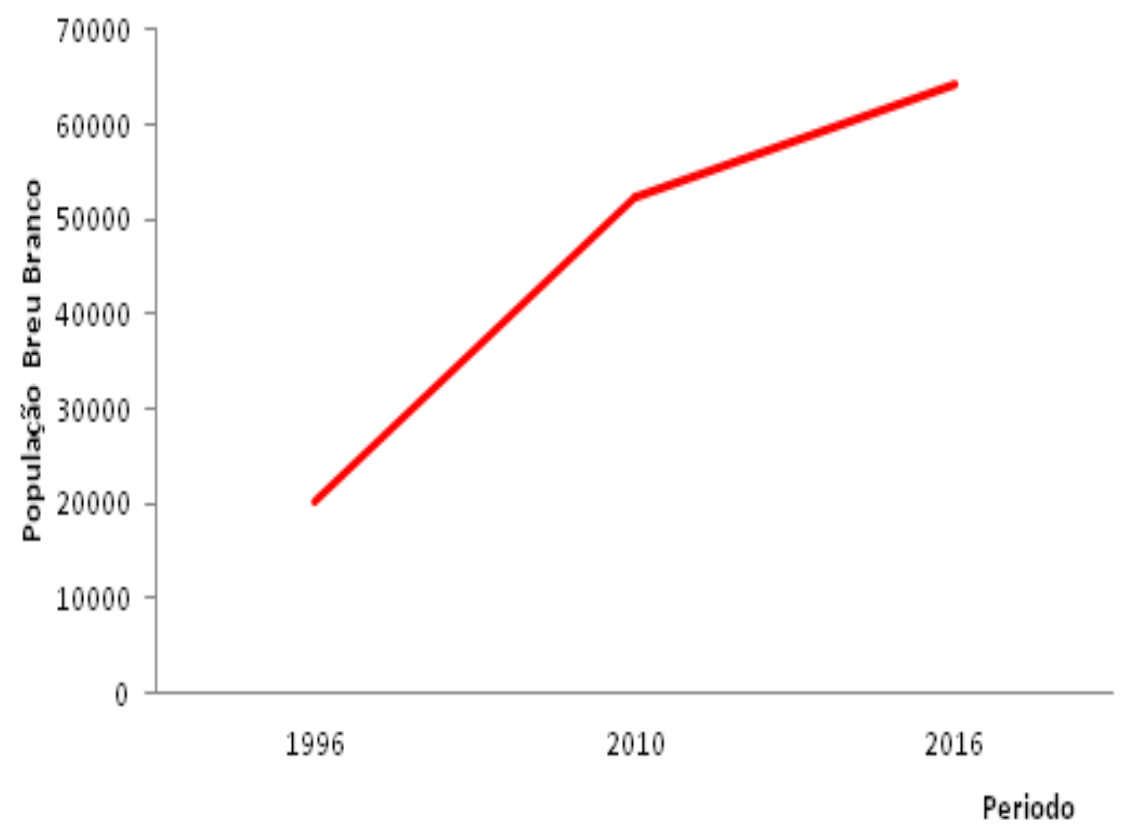

Fonte: Elaborado pelo autor, 2019.

\section{Dinâmica territorial}

Os momentos econômicos no município ditaram a velocidade de apropriação urbana sobre a floresta. Partindo da configuração espacial inicial da zona urbana, concentrada em um primeiro momento na porção sul do que é o município hoje, a população antes de 1996, se concentrava entre a Rodovia PA-263 e as margens do reservatório da barragem no rio Tocantins. O segundo momento, que vai de 1996 a 2006, apresenta no território o resultado do crescimento populacional, principalmente na porção norte da sede, sobre áreas verdes. A análise da Fígura 2, mostra a configuração espacial urbana nesse período, a PA-263 limitava o núcleo urbano, ao norte do município, e o comportamento da cobertura vegetal era de padrão relevante. A área rural ao norte da rodovia foi convertida em poucos anos em ocupações espontâneas e posteriormente em bairros. Esse avanço permite inferir que houve uma supressão vegetal de aproximadamente $2,3 \mathrm{~km}^{2}$. 
Fígura 2 - Área urbana de Breu Branco em 1996

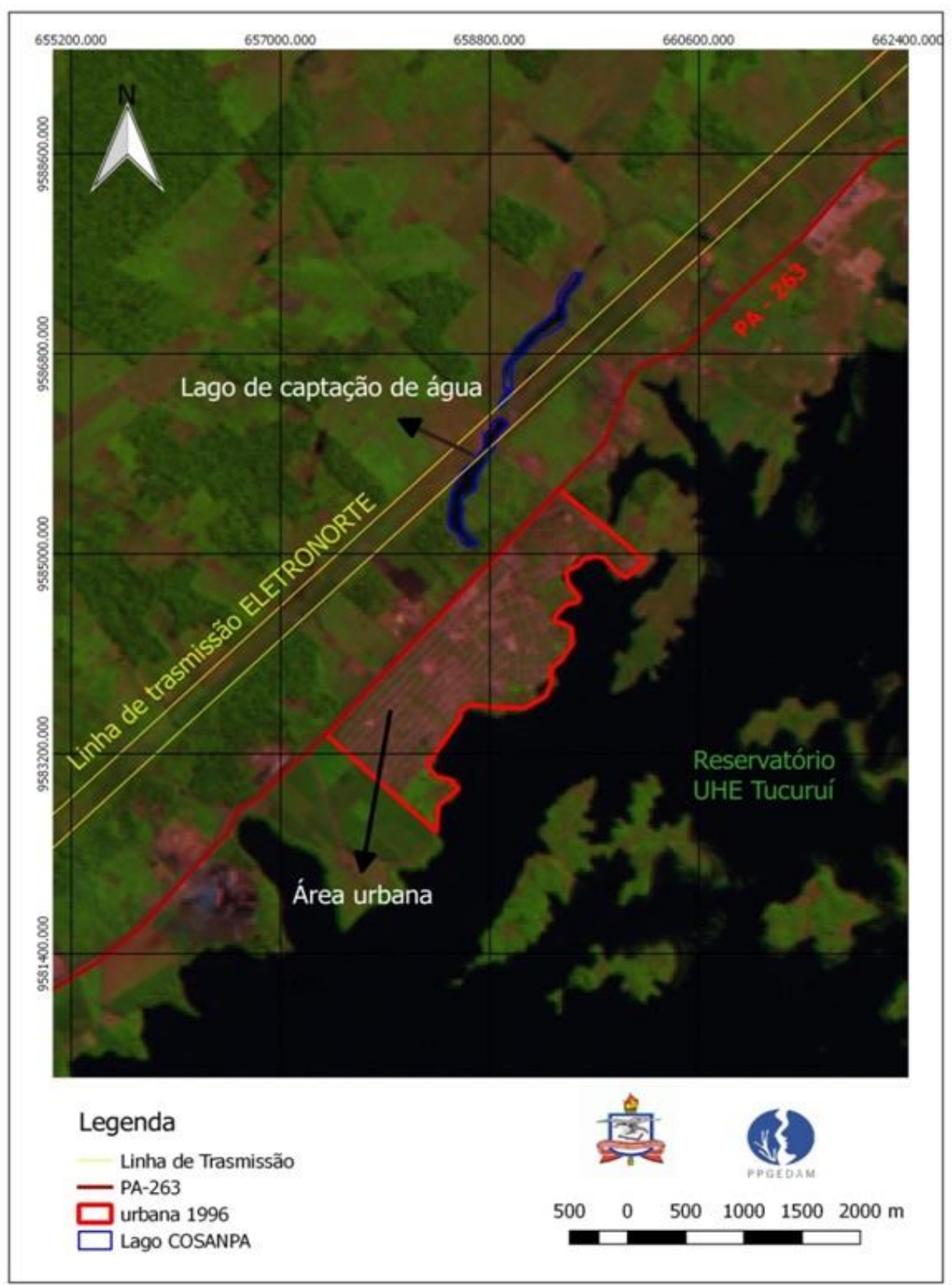

Fonte: Elaborado pelo autor, 2019.

Em 2006, a população de Breu Branco, segundo o IBGE, era da ordem de 46 mil habitantes, ou seja, a população saiu de aproximadamente 20.000 para 46.000 habitantes, um crescimento de aproximadamente $130 \%$ em dez anos. Sua área territorial saiu de $3,8 \mathrm{~km}^{2}$ para aproximadamente 6 km². Em 2006, o Plano Diretor de Breu Branco, fazia referência a existência de sete bairros, incluindo os já consolidados na parte sul, mas sua área territorial já era quase o dobro de sua área emancipada.

A linha de transmissão de energia elétrica, transversal ao movimento de crescimento 
horizontal, funcionou como uma barreira física para o avanço dos bairros; Santa Catarina, Conquista e Liberdade. Porém, não impediu que ao redor do lago de captação, fosse ocupado. Quando observamos o mapa de 1996 (Fígura 3), claramente observamos que não havia pressão urbana no entorno do lago. A expansão territorial, na região do bairro Conquista e Liberdade sobre a vegetação, resultou na mudança da paisagem no entorno do lago. Com base nas mensurações de distância realizadas em ambiente SIG (Sistema de Informação Geográfica), a evolução urbana em direção ao lago, equivale a um avanço de aproximadamente 60 metros por ano, ou seja, esse valor está relacionado à velocidade de conversão de biomassa vegetal em cidade. A seguir, a Figura 3 mostra a evolução territorial da área urbana de Breu Branco no período de estudo. A cor vermelha representa a classe solo, que apresenta o comportamento espectral da área urbana contendo solo exposto, e áreas residenciais, na cor verde, a vegetação mais clara é vegetação secundária, em verde escuro a vegetação é ombrófila, e na cor azul os espelhos de água e parte do reservatório da UHE Tucuruí.

Figura 3 - Dinâmica espacial e temporal da área urbana de Breu Branco - PA.

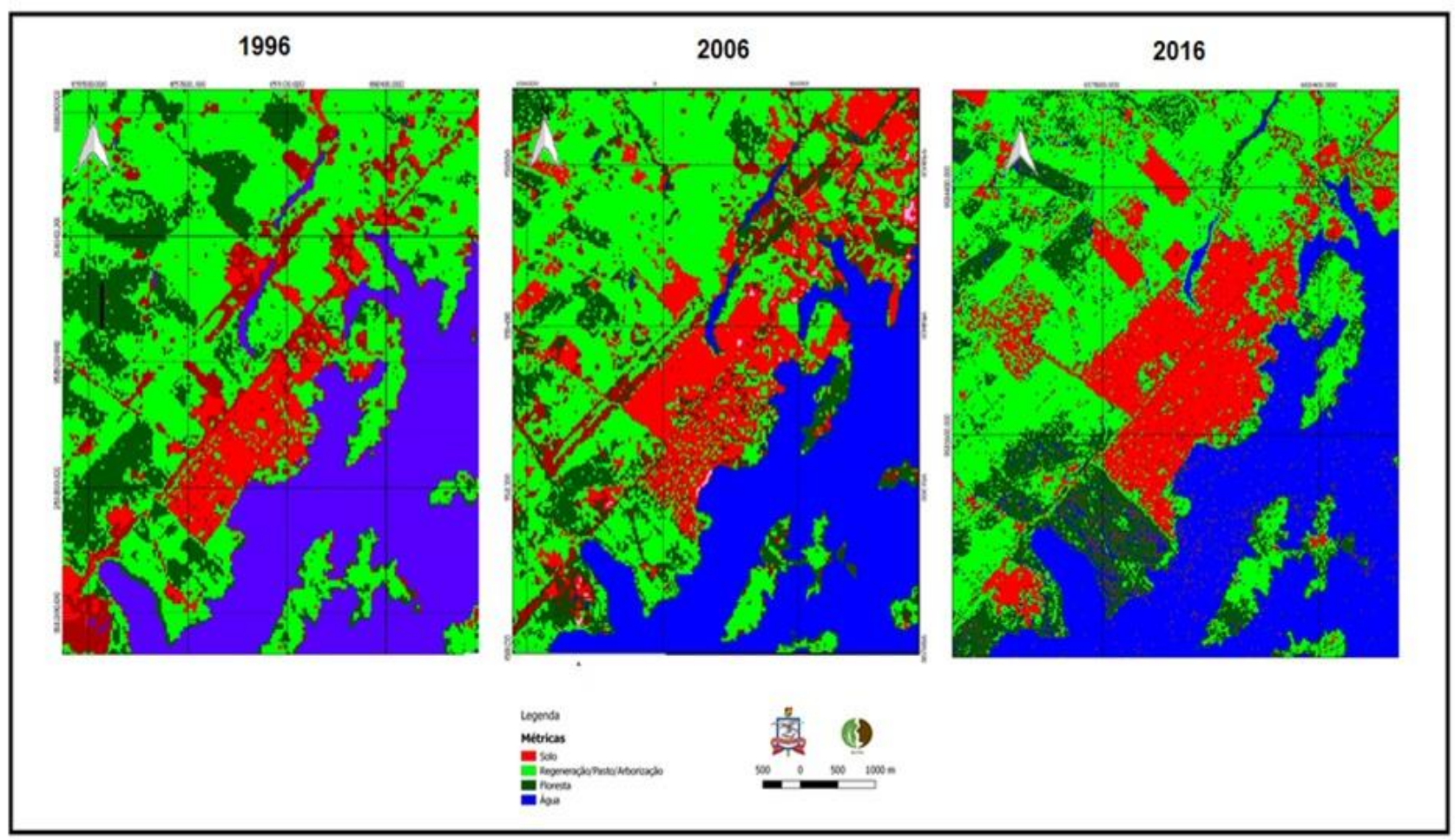

Fonte: Elaborado pelo autor, 2019.

\section{Elementos tendenciais a expansão urbana}

Vamos abordar alguns elementos que considerados relevante para a expansão da área urbana de Breu Branco, como a topografia, o a valor da terra e a condição ambiental. 


\subsection{Topografia}

Para analisar o nível de declividade do solo em Breu Branco, geramos um MDE - Modelo Digital de Elevação, a partir de curvas de nível também extraídas de imagens do Shuttle ou Missão Topográfica de Radar (SRTM), produzindo o mapa da Figura 4 a seguir, onde os níveis de declividade são expressos por cores, em que varia do tom pastel para área de menor declive a tons avermelhados para área de maior declividade.

A área urbana de Breu Branco, conforme o modelo de elevação está sobre uma área com baixos valores de declividade, ou seja, área plana, em função da cor do gradiente de declividade onde estão os polígonos do município que representam a área urbana consolidada, percebe-se que o centro e seu entorno possuem topografia regular, sua declividade é de 0 a $3 \%$ na maioria das áreas urbanas e periurbanas, a variação da declividade nas áreas de expansão podem variar à $8 \%$, apresentando um relevo plano e suavemente ondulado.

Figura 4 - Altimetria da área urbana de Breu Branco.

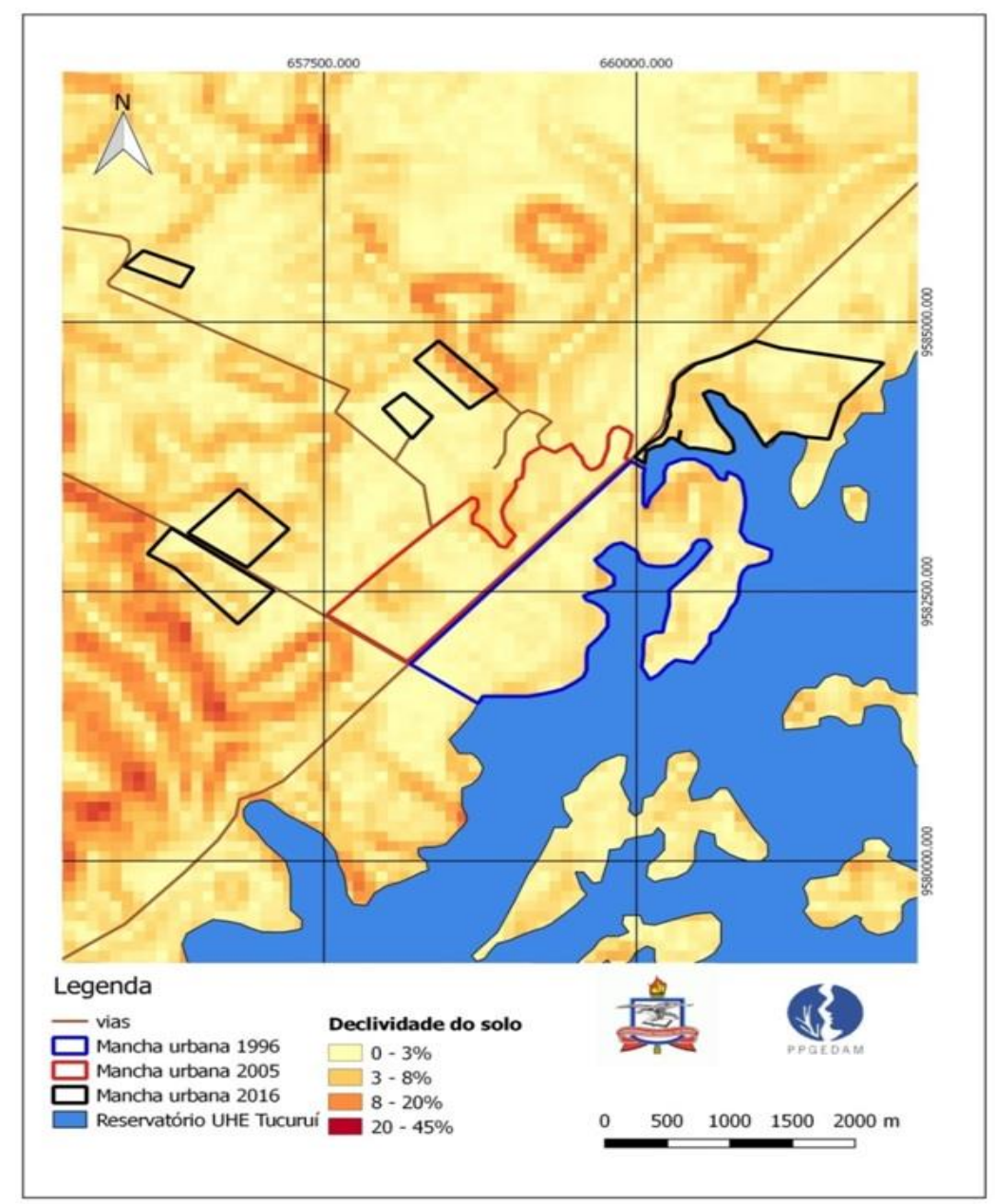

Fonte: Elaborado pelo autor, 2019. 


\subsection{Valor da Terra}

Partimos da comparação entre os valores da terra em área urbana e rural, por metro quadrado. $\mathrm{Na}$ área rural a estimativa do metro quadrado foi feita com base no Valor da Terra Nua - VTN, publicados pelo Instituto de Terras do Pará (ITERPA). Segundo a resolução ${ }^{\circ} 001$ de abril de 2015 do Conselho Estadual de Política Agrícola - CEPAF. Capítulo 01, Art. 02, o cálculo do VTN adota os fatores distância, ancianidade, acesso e dimensão da área, sobre os quais incidirão índices correspondentes às características do imóvel, que exercem influência no valor de referência do hectare do município. O Valor da Terra Nua é obtido com a aplicação dos índices dos respectivos fatores sobre o valor de referência do hectare, mediante o emprego da expressão:

\section{VTN $=($ VrT $x$ IFa $x$ IFb $\times$ IFc $x$ IFd $) \times$ Sr}

Onde:

VTN $=$ Valor da Terra Nua VrT = Valor de Referência da Terra para o município de inserção da área requerida, em reais $\mathrm{IFa}=$ Índice do fator distância à sede municipal ou ao centro urbano mais próximo $\mathrm{IFb}=$ Índice do fator acesso ao imóvel IFc = Índice do fator ancianidade da ocupação $\mathrm{IFd}=$ Índice do fator dimensão da área $\mathrm{Sr}=$ Área requerida (em hectare)

Considerando as microrregiões geográficas, na Tabela 1 segue o valor do hectare na zona rural dos municípios da região de integração do lago de Tucuruí:

Tabela 1. Valor do VTN, na microrregião de Tucuruí, segundo o ITERPA.

\begin{tabular}{ccc}
\hline Microrregião & Munícipio & Valor do hectare \\
\hline & Breu Branco & $\mathrm{R} \$ 878,00$ \\
Nova Ipixuna & $\mathrm{R} \$ 945,00$ \\
Tucuruí & Itupiranga & $\mathrm{R} \$ 825,00$ \\
& Jacundá & $\mathrm{R} \$ 878,00$ \\
& Novo Repartimento & $\mathrm{R} \$ 878,00$ \\
& Tucuruí & $\mathrm{R} \$ 878,00$
\end{tabular}

Fonte: Dados produzidos pelo Instituto de Terras do Pará - ITERPA, (2015). Adaptado pelo autor, 2019. 
Considerando que o hectare na zona rural de Breu Branco custa 878,00 reais, e que 1 (um) hectare equivale a uma área de 100 x 100 metros lineares, ou seja, o hectare possui 10.000 (dez mil) metros quadrados, analogamente 1 (um) metro quadrado de terra nua em Breu Branco custa 0,087 reais. Vale observar que o VTN é um valor de referência, e não inclui as benfeitorias existentes no imóvel, expressando somente o valor da terra, porém é o valor estipulado tecnicamente para valoração de imóveis na área rural. Os dados referentes ao valor de imóveis na área urbana foram obtidos com base em pesquisas junto a Secretaria de Finanças de Breu Branco (SEFIN), e através de pesquisas em imóveis com placas de venda na parte central da sede. Os valores aproximados seguem na tabela 2:

Tabela 2. Estimativa de valor da terra, na cidade de Breu Branco.

\begin{tabular}{cccc}
\hline Bairro & Valor estimado & $\begin{array}{c}\text { Valor médio do } \\
\mathbf{m}^{\mathbf{2}}\end{array}$ & Condição urbana \\
\hline Centro & $50.000,00-200.000,00$ & 416,70 & Consolidado \\
Liberdade & $10.000,00-15.000,00$ & 41,80 & Em consolidação \\
Vilela & $5.000,00-8.000,00$ & 21,60 & Expansão \\
Castanheira & $3.000,00-5.000,00$ & 13,30 & Expansão \\
União & $2.000,00-3.000,00$ & 8,30 & Expansão \\
\hline
\end{tabular}

Os valores do metro quadrado no bairro Centro, foi o mais elevado, apresentando um valor aproximado de $416,70 / \mathrm{m}^{2}$. Vale observar que esse bairro, possui os principais serviços urbanos de Breu Branco, além de ter boas vias de circulação, drenagem de água pluvial, coleta regular de lixo, escolas e universidades, além de agências bancárias e a sede da prefeitura. Esse bairro foi organizado para receber os habitantes das terras alagadas pelo reservatório da UHE e alguns trabalhadores da usina no fim da década de 80 (FEARNSIDE, 2005), é o bairro mais antigo de Breu Branco. Quando comparamos o valor do metro quadrado do Centro, com os demais bairros a diferença é significativa. $\mathrm{O}$ bairro de Liberdade tem o metro quadrado de aproximadamente 41,80 reais, e foi formado sobre áreas rurais entre os anos de 2000 e 2005, no contexto da segunda fase da barragem. O Vilela, é uma ocupação recente, fica localizado as margens da PA 263 no sentido do município de Goianésia, e não apresenta infraestrutura urbana como os outros bairros citados, mas o valor do metro quadrado é diferente dos outros bairros em zona de expansão $\left(21,60\right.$ reais $\left./ \mathrm{m}^{2}\right)$, provavelmente por estar localizado às margens da rodovia e ainda no lado sul do município próximo a região central. 
Os bairros do Castanheira e União, tiveram os menores valores em metro quadrado, os dois bairros também foram áreas de ocupação espontânea, ao longo da avenida Galet, com precárias instalações urbanas, ficam localizados no fim da zona urbana do município, limitando com áreas rurais ao norte. $\mathrm{O}$ valor do metro quadrado estimado foi de 13,30 e 8,30 reais $/ \mathrm{m}^{2}$, respectivamente.

\subsection{Fatores Ambientais}

A busca por um contexto urbano justo e ambientalmente aceitável tem sido muito discutida nos últimos anos. A saída viável para o modelo de desenvolvimento urbano atual, só é possível do ponto de vista sustentável. Porém urbano e ambiental foram conceitos separados por muito tempo, parecendo coisas opostas (COSTA, 1999). Com o crescimento urbano ganhando espaço como temática, várias discussões sobre modelos de cidade têm sido adotados, além de diversas alternativas de ordenamento espacial, como zoneamento ambiental nas áreas urbanas (BARBOSA, 2010; BATISTELA 2007) ou Zoneamento de Interesse Social para regularização de áreas ocupadas espontaneamente (MIRANDA, 2007). A lagoa de captação de água para abastecimento da cidade de Breu Branco está localizada entre os bairros Conquista e Liberdade. Possuindo uma área de aproximadamente $111 \mathrm{mil} \mathrm{m}^{2}$, apresenta características no seu entorno, diferente do que se espera de uma área de proteção ambiental. Segundo a Lei federal de 12.651/2012, os rios ou lagos em áreas urbanas, fazem parte da paisagem e da vida da urbe. Entende-se por Área de Preservação Permanente (APP): “Área protegida, coberta ou não por vegetação nativa, com a função ambiental de preservar os recursos hídricos, a paisagem, a estabilidade geológica e a biodiversidade, facilitar o fluxo gênico de fauna e flora, proteger o solo e assegurar o bem-estar das populações humanas." Segundo Castro et al (2018), o entorno de lagoas, lagos e reservatórios naturais possuem faixas de preservação variando de 30 a 100 metros de largura, a depender de sua localização e área superficial. O crescimento da cidade, a demanda por espaço, empurram os menos favorecidos em direção aos recursos naturais. A perspectiva de cidades ambientalmente justas e sustentáveis considera que os espaços urbanos devem ser planejados, destinados de acordo com o uso econômico, social e ambiental (Rocha et al, 2018). A falta de planejamento como no caso de Breu Branco, uma cidade fundada em 1991, permitiu que as ocupações ocorressem desordenadas, principalmente na parte norte da sede do município, a consequência desse processo, fica evidente quando a imagem de satélite da Figura 5, mostra o entorno da área do lago no ano de 2018, totalmente ocupada no entorno, ainda há de se considerar, que sobre o lago, existe a rede de energia elétrica do linha de distribuição de Tucuruí, ou 
seja, se não fosse a existência da linha, hoje o lago poderia ser ainda mais obstruído. Para dimensionar as ocupações em relação ao bordo do lago, elaboramos uma linha perimetral com base nas normas de proteção ambiental definidas pelo novo código florestal. Segundo o código florestal no seu artigo $4^{\circ}$, o limite de área de APP, para lagoas em áreas urbanas, deve ser uma faixa continua de preservação, correspondente a 30 metros da linha de água do lago.

Utilizando as ferramentas cartográficas, construímos o limite da faixa de APP, conforme a Figura 5. Como resultado a área de Preservação Permanente do lago de captação de Breu Branco deveria ter hoje aproximadamente $88 \mathrm{mil} \mathrm{m}^{2}$, livre de ocupações e preferencialmente com uma boa cobertura florestal.

Figura 5 - Buffer da área de preservação do lago de captação.

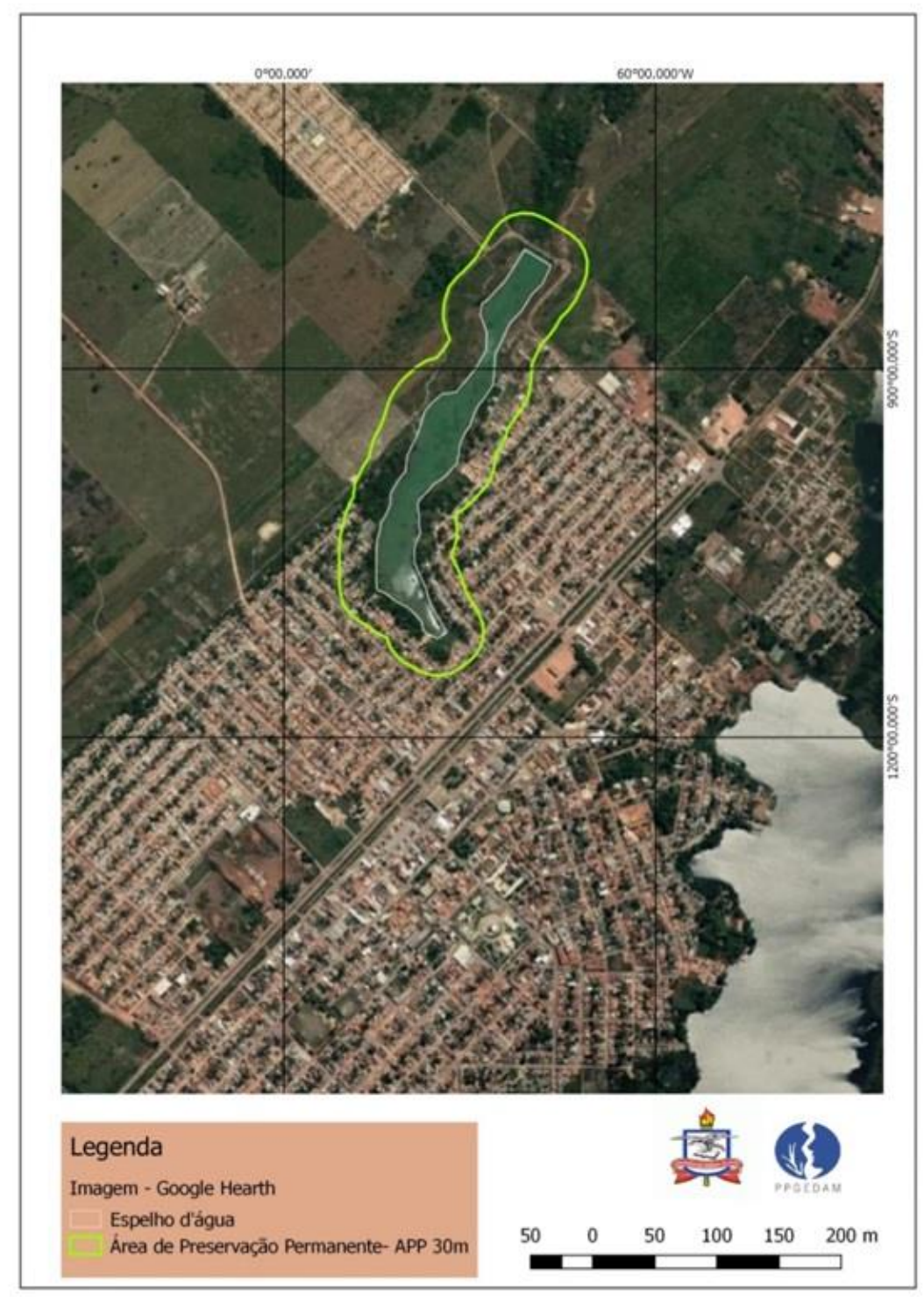

Fonte: Elaborado pelo autor, 2019. 
É importante lembrar, que o Plano Diretor Municipal de Breu Branco (2006-2016), não fez referência às áreas de proteção ambiental urbanas do município. Segundo Castro et al (2018), as definições na medida provisória (MP) 2.166-67 de 2001 em relação a área de APP em zonas urbanas, foi integralmente mantida no novo código florestal de 2012, ou seja, não houve atenção do planejamento publico para a questão ambiental em Breu Branco.

\section{Considerações finais}

As características de uso e ocupação urbana em Breu Branco estão intrinsecamente ligadas à construção da hidroelétrica de Tucuruí. A produção do espaço urbano reflete a forma como o capital na lógica da barragem, influenciou a formação do espaço urbano, amplamente discutido por Lafebvre (2001), em o "direito a cidade".

Em pouco mais de 10 anos, Breu Branco triplicou sua população e duplicou sua área urbana. Vários bairros surgiram da ocupação de terras públicas e privadas.

A construção dos planos diretores não aconteceu como estratégia de gestão. O crescimento urbano sobre áreas verdes comprova que não houve uma sequencia de políticas públicas voltadas para o desenvolvimento territorial.

O conceito de Zonas Especiais de Interesse Social - ZEIS, previstas no estatuto das cidades lei (10.257/2001), que tem a função de delimitar espaços públicos para implantação de Habitações de Interesse Sociais - HIS, pode ser uma boa ferramenta de gestão territorial para os próximos anos.

\section{Referências}

BARBOSA, C.; CARVALHO, P. F. Zoneamento urbano-ambiental: possibilidades de compatibilização entre análise geomorfológica e padrões de ocupação urbanos para a construção de cidades sustentáveis. In: seminário latino americano de geografia física, 6.; seminário ibero americano de geografia física, 2., 2010, Coimbra. Anais... Universidade de Coimbra, 2010.

BATISTELA, T. S. O zoneamento ambiental e o desafio da construção da gestão ambiental urbana. 2007. 159 f. Dissertação (Mestrado em Arquitetura e Urbanismo) - Faculdade de Arquitetura e Urbanismo, Universidade de Brasília, Brasília.

BECKER, B. K. Amazônia: geopolítica na virada do III milênio. 6. ed. São Paulo: Ática, 1998. BECKER, B. K. O governo do território em questão: uma perspectiva a partir do Brasil. Parcerias Estratégicas, Brasília, v. 14, n. 28, p. 33-50, jan./jun. 2009. 
Presidência da República. Lei n. 10.257, de 10 de julho de 2001. Estabelece diretrizes gerais da política urbana e dá outras providências. Diário Oficial da União, Brasília, DF, 11 jul. 2001. Disponível em:<https://www2.camara.leg.br/legin/fed/lei/2001/lei-10257-10-julho2001-327901-publicacaooriginal-1-pl.html>. Acesso em: 19 abr. 2019.

Presidência da República. Lei n. 12.651, de 12 de maio de 2012. Dispõe sobre vegetação nativa. Diário Oficial da União, Brasília, DF, 25 maio. 2012. Disponível em: <https://

http://www.planalto.gov.br/ccivil_03/_ato2011-2014/2012/lei/112651.htm>. Acesso em: 06 outubro. 2020.

BREU BRANCO. Prefeitura Municipal. Plano diretor do município de Breu Branco. 2006. Disponível em:<http://www.sedurb.pa.gov.br/pdm/breu_branco/Plano_Diretor.pdf >. Acesso em 18 abr. 2019.

CASTRO, S.L.I.; MAY, L.R.; GARCIAS, C,M.; Meio ambiente e cidades - áreas de preservação permanente (apps) marginais urbanas na lei federal n. 12.651/12. Ciênc. Florest. vol.28 no.3 Santa Maria July/Sept. 2018. jul./dez. 2009.

COSTA, H. S. M. Desenvolvimento urbano sustentável: uma contradição de termos?. Revista brasileira de estudos urbanos e regionais, n. 2, nov. 1999.

EMBRAPA. Centro Nacional de Pesquisa de Solos. Manual de métodos de análise de solo. 1. ed. Rio de Janeiro, 1997. 212 p.

FEARNSIDE, Philip M.: Hidrelétricas na Amazônia: impactos ambientais e sociais na tomada de decisões sobre grandes obras. Manaus: Editora do INPA, 2015.

GIL, A. C. Como elaborar projetos de pesquisa. Métodos e técnicas de pesquisa social, São Paulo, v. 6, p. 22-23, 1999

INSTITUTO BRASILEIRO DE GEOGRAFIA E ESTATÍSTICA - IBGE. Estimativas da população residente nos municípios e para as unidades da federação brasileiros com data de referência em $\mathbf{1}^{\mathbf{0}}$ de julho de 2016. Rio de Janeiro: IBGE, 2016.

INSTITUTO NACIONAL DE PESQUISAS ESPACIAIS - INPE. Sistema de Processamento de Informações Georeferenciais: classificação de imagens. 
2006. Disponível em:<http://www.dpi.inpe.br/spring/portugues/tutorial/classific.html >. Acesso em: 25 abr. 2019.

LAFEBVRE, Henri. O direito à cidade. Tradução de Rubens Eduardo Frias. 5 ed. São Paulo: Centauro, 2001.

LOCATELli, Selena. Plano Amazônia Sustentável: uma nova concepção estatal de desenvolvimento para a Amazônia?. 2009. 107 f. Dissertação (Mestrado em Sociologia) - Instituto de Ciências Sociais, Universidade de Brasília, Brasília.

MASCARENHAS, A. L. S.; VIDAL, M. R. Declividade e hipsometria do perímetro urbano da cidade de Marabá-PA: aportes conceituais de geomorfologia urbana. In: CONGRESSO BRASILEIRO DE GEOGRÁFOS, 7., 2014, Vitória. Anais... Vitória: AGB, 2014.

MARTINS, K. G. Expansão urbana desordenada e aumento dos riscos ambientais a saúde humana: o caso brasileiro. 2012. 65 f. Monografia (Graduação em Gestão Ambiental) - Faculdade UnB Planaltina - Universidade de Brasilia, Planaltina, DF.

MIRANDA, Lívia; MORAES, Demóstenes. O Plano de Regularização das Zonas Especiais de Interesse Social (Prezeis) do Recife: democratização da gestão e planejamento participativo. Habitação social nas metrópoles brasileiras: uma avaliação das políticas habitacionais em Belém, Belo Horizonte, Porto Alegre, Recife, Rio de Janeiro e São Paulo no final do século XX. Porto Alegre: IPPUR, 2007.

RAFFESTIN, C. Por uma geografia do poder. Tradução de Maria Cecília França. São Paulo: Ática, 1993.

ROCHA, G. Reordenamento territorial e político-institucional e desenvolvimento local na Amazônia: o caso de Tucuruí (PA). In: Encontro de Geógrafos da América Latina, 10., 2005, São Paulo. Anais... São Paulo: Universidade de São Paulo, 2005.

ROCHA, G.; TEISERENC, P; VASCONCELLOS SOBRINHO, M. Aprendizagem territorial: dinâmicas territoriais, participação social e ação local na Amazônia. Belém: Núcleo de meio ambiente, UFPA, 2016.

ROCHA, G.; TEISERENC, P; VASCONCELLOS SOBRINHO, M. Cidades, comunidades e territórios. Belém: Núcleo de meio ambiente, UFPA, 2018. 
XAVIER, S. C; BASTOS, C. A. B. Estudo do crescimento urbano aplicado ao mapeamento geotécnico: uma metodologia de análise. Revista Brasileira de Cartografia, n. 62/04, 2010. 
http://dx.doi.org/10.18542/rmi.v14i22.9649

\section{AS ORGANIZAÇÕES NÃO GOVERNAMENTAIS E O PROGRAMA CISTERNAS EM BARREIRA (CE)}

\section{NON-GOVERNMENTAL ORGANIZATIONS AND THE CISTERNAL PROGRAM IN BARREIRA (CE)}

Victória de Sousa XAVIER ${ }^{1}$

Universidade da Integração Internacional da Lusofonia Afro-brasileira

Andrea Yumi Sugishita KANIKADAN ${ }^{2}$

Universidade da Integração Internacional da Lusofonia Afro-brasileira

\begin{abstract}
Resumo: O presente trabalho propõe-se a estudar o Programa de Cisternas, implementado na região rural do município de Barreira (CE), uma vez que o acesso à água é um tema frequentemente discutido na comunidade. Na região, os problemas acerca do abastecimento de água são diversos, principalmente para as comunidades mais afastadas do centro da cidade. Trata-se de identificar em que medida a população-alvo foi beneficiada pelo programa, cuja iniciativa pertence a duas organizações não governamentais atuantes no local, uma nacional e a outra internacional. Utilizou-se a pesquisa qualitativa, com técnicas de pesquisa bibliográfica $e$ documental, além da aplicação de entrevistas às famílias participantes do programa. Os resultados da pesquisa, mostram que o programa trouxe melhorias, tais como a facilidade e garantia no acesso à água, porém suscita questões muito mais profundas e complexas relacionadas à aspectos financeiros, de gênero, políticos $e$ de desenvolvimento local.
\end{abstract}

Palavras-chave: Terceiro setor. Organizações não governamentais. Programa de Cisternas.

\begin{abstract}
This study aims to analyze the Cisterns Program, implemented in the rural region of the Barreira city (CE). The access to water is a topic frequently discussed in the community. In the region, water supply problems are diverse, especially for communities located far away from downtown. It intends to identify the extent to which the target population was benefited by the program, whose initiative belongs to two nongovernmental organizations operating on the location, a national and an international ones. It was conducted a qualitative research, with bibliographic and documentary research techniques, in addition to the application of interviews to families attending the program. The survey results show that the program has brought improvements, such as ease and guarantee access to water supply, but it raises much deeper and more complex issues related to financial, gender, political and local development aspects.
\end{abstract}

Keywords: Third sector. Non-governmental organizations. Cisterns Program

\footnotetext{
${ }^{1}$ Graduada em Administração Pública pela Universidade da Integração Internacional da Lusofonia Afro-Brasileira. Email: victoria.xavier.397@gmail.com

2 Doutora em Ecologia Aplicada da Escola Superior de Agricultura Luiz de Queiroz da Universidade de São Paulo ESALQ/USP, professora adjunta do curso de Administração Pública do Instituto de Ciências Sociais Aplicadas da Universidade da Integração Internacional da Lusofonia Afro-Brasileira (ICSA/UNILAB). E-mail: akanikadan@unilab.edu.br
} 


\section{Introdução}

Os problemas sociais, tais como desigualdade, desemprego, violência, criminalidade, saúde precária, baixo investimento em educação, ausência de habitação estiveram sempre presentes na história da vida em sociedade. A região Nordeste, com uma área de 1.554.291,744 km², questões relacionadas à seca e a escassez de água são recorrentes. São $982.566 \mathrm{~km}^{2}$ de extensão do Semiárido brasileiro, cerca de $18 \%$ do território nacional. No Ceará, é onde está concentrada a maior parte deste semiárido; segundo a Articulação no Semiárido Brasileiro (ASA Brasil), são 175 municípios cearenses que fazem parte deste espaço (ASA, 2019).

A ASA Brasil caracteriza o semiárido como região com baixo volume de chuvas, com alta variabilidade espacial e temporal responsável pelas secas e a baixa absorção de água no solo. Em todo o Nordeste, é sabido dos problemas relacionados à água, seja por fatores estruturais, como problemas nas gestões locais e ausência de políticas públicas; seja por fatores naturais, como o clima e temperatura, escassez de água nos rios e de chuvas, que atingem diretamente as casas de muitas famílias no interior do Ceará. No município de Barreira (CE), que faz parte do semiárido brasileiro, essa situação não é diferente, os problemas de falta de água são frequentes.

No entanto, as ações e políticas sociais que buscam lidar com essas questões ainda não são suficientes. As discussões sobre o semiárido brasileiro são crescentes; nota-se um cenário de preocupação com o bem-estar das famílias que vivem nessa realidade. Com isso duas organizações não governamentais engajaram-se nessa causa. A Associação Internacional ${ }^{3}$ criou o Programa de Cisternas em cooperação com a Organização $\mathrm{Nacional}^{4}$. O programa tem como objetivo auxiliar pela construção de cisternas, a captação de água para famílias que estão localizadas nas áreas mais afastadas do acesso a água no estado do Ceará. Com isso, o presente trabalho busca responder a seguinte questão: Em quais aspectos da vida dessas famílias foi percebida uma maior melhoria após o programa?

Este trabalho justifica-se pela necessidade de se compreender o papel das organizações não governamentais na execução de projetos sociais. Deseja-se conhecer a sua efetividade na utilização dos recursos, na perspectiva dos beneficiários dos projetos e sua contribuição para a gestão pública.

A partir das questões levantadas, o objetivo geral deste estudo é: analisar o Programa de Cisternas desenvolvido pela Associação Internacional em cooperação com a organização Nacional e

\footnotetext{
${ }^{3}$ Optou-se por omitir o nome das organizações não-governamentais

${ }^{4}$ Idem
} 
observar os aspectos que melhoraram as vidas das famílias beneficiadas do município de Barreira no Estado do Ceará.

\section{Terceiro Setor e as Organizações Não Governamentais (ONGs)}

O termo terceiro setor é apresentado como uma justificativa ideológica do desengajamento das ações do Estado (FRANÇA FILHO, 2002). Por isso, na década de 90 é que o terceiro setor teve grande consolidação, com a criação da Lei do Terceiro Setor, a qualificação de Organizações da Sociedade Civil de Interesse Público, as OSCIPs, o que permitiu parcerias com órgãos públicos e privados (OLIVEIRA \& GODÓI-DE-SOUSA, 2015).

No Brasil, o terceiro setor tem início com movimentos religiosos da época, mais especificamente com a criação da Santa Casa de Misericórdia de Santos, em 1943, que tinha apoio da Igreja Católica. Com o regime militar e devido às várias mudanças que ocorreram nessa época, os movimentos sociais ganharam força diante da crescente onda de insatisfação da população referente à política (DE ALBUQUERQUE, 2006).

O Terceiro Setor corresponde a fundações, associações, organizações não governamentais, entidades filantrópicas, ou seja, instituições de iniciativa privada sem fins lucrativos (FERNANDES, 1994). Segundo Salomon e Anheier (1992, apud, FRANÇA FILHO, 2002, p. 10.) e segundo a pesquisa intitulada As Fundações Privadas e Associações sem fins Lucrativos no Brasil - FASFIL, são utilizados os critérios elaborados pela ONU junto a Universidade John Hopkins (IBGE, 2019) para caracterizar as organizações do terceiro setor, ou seja, devem apresentar cinco características essenciais, sendo elas: 1) formais ou legalmente constituídas; 2) privadas, que não integram o aparelho do Estado; 3) independentes, tendo capacidade de administrar suas próprias ações e atividades; 4) sem fins lucrativos, que não terão como principal finalidade a geração de lucros, podendo ainda tê-los e não serão distribuídos para os seus integrantes; 5) apresentar certo nível de participação voluntária. França Filho (2002) complementa e diz que estas organizações não devem fazer parte de partidos políticos e nem ser de gênero religioso.

Por muito tempo as organizações do terceiro setor enfrentaram dificuldades com relação a sua regulamentação, uma vez que não existiam normas que as regulassem, além de dificuldades relacionadas à captação de recursos, principalmente as pequenas instituições. Esses fatores trouxeram como consequência a ausência de controle de recursos, da prestação de contas e de verificadores da atividade prestada. Foi criada a Lei 13.019/2014, sancionada em 31 de julho de 2014, estabelecendo 
o Marco Regulatório das Organizações da Sociedade Civil (MROSC), que regulamentou as parcerias entre a Administração Pública e as Organizações da Sociedade Civil. A lei define, além de outros pontos, diretrizes para o fomento da colaboração dos governos com organizações da sociedade civil.

As Organizações da Sociedade Civil (OSC) refere-se a um termo empregado recentemente pela Lei do Terceiro Setor, considerando qualquer entidade privada sem fins lucrativos com objetivo social, as sociedades cooperativas e as organizações religiosas. Nesse conceito, encontram-se as Organizações não Governamentais (ONGs), entidades criadas para atender as necessidades da população compostas pela própria sociedade.

As Organizações não governamentais foram utilizadas popularmente para se referir a qualquer organização social, porém juridicamente, as organizações não governamentais são correspondentes às fundações e associações. Por muito tempo, utilizou-se o termo para designar organizações dos movimentos populares, organizações filantrópicas e de caridade, assim Organizações Sociais, Associações e ONGs eram tidas como sinônimo. "Quando falamos de Organizações Não Governamentais - ou ONGs - no seu sentido mais estrito, falamos de organizações ligadas ao desenvolvimento e à defesa de direitos, ou seja, de uma parte da sociedade civil no seu sentido mais politizado" (MENDONÇA, 2013, p.8).

No Brasil, as ONGs aparecem com maior significado no período da ditadura militar através da resistência da população em lutar pelos seus direitos e necessidades. Mas o termo ONG foi entendido e começou a ser consolidado na conferência mundial da Organização das Nações Unidas - ONU, no Rio de Janeiro, Brasil, na Eco-92, como sinônimo de entidades sem fins lucrativos (OLIVEIRA \& HADDAD, 2001).

As ONGs são entidades do terceiro setor, de caráter privado, que tem como função desenvolver trabalhos e atividades sem a finalidade de obter lucro. As ONGs tem atuação diversificada, podendo exercer trabalhos nas áreas sociais, de saúde, ambientais, entre vários outros. Assim como foi falado sobre o terceiro setor, as ONGs surgiram como parte dele, com o objetivo de suprir a ausência do Estado com relação a sua atuação em benefício da sociedade.

Para a Associação Brasileira de Organizações não governamentais (ABONG), segundo o que está disposto em seu estatuto no art. $2^{\circ}$, são consideradas Organizações Não Governamentais, as entidades juridicamente constituídas sob a forma de fundação ou associação, sem fins lucrativos, autônomas e pluralistas. Elas devem ter o compromisso com a construção de uma sociedade democrática, participativa e com o fortalecimento dos movimentos sociais de caráter democrático, atestadas pelas suas trajetórias institucionais e pelos termos dos seus estatutos (ABONG, 2016). 
Trabalham em defesa de uma causa social e/ou política. As ONGs surgiram principalmente em locais e regiões que buscavam a solução para grandes problemas. Muitas delas atuam em comunidades distantes com pouco ou nenhum acesso às políticas governamentais.

O Marco Regulatório das Organizações da Sociedade Civil - MROSC trouxe a normatização para estas organizações, e aquelas notícias sobre ONGs corruptas que praticaram violações diminuíram, uma vez que o controle sobre essas organizações é maior.

\section{Financiamento das Organizações da Sociedade Civil: a Cooperação Internacional}

As principais fontes de financiamento das organizações da sociedade civil são: Recursos Públicos, Cooperação Internacional para o Desenvolvimento, Novos Formatos de Mobilização de Recursos e Investimento Social Privado (ISP) (MENDONÇA et al, 2013).

O Instituto de Pesquisa Econômica Aplicada - IPEA (LOPEZ \& ABREU, 2014) publicou uma pesquisa acerca do que mobilizou o Estado a cooperar com ONGs na implementação de políticas públicas. Com a pesquisa, foi possível considerar que a parceria entre Estado e ONGs está imputada em suas capacidades no que diz respeito à expertise, a capilaridade, a flexibilidade e ao engajamento nas políticas propostas. Ou seja, as ONGs trabalham com mais proximidade dos beneficiários, isso faz com que entendam e definam melhor as necessidades deles.

Por outro lado, a burocracia é importante na implementação de políticas, considerando sua infraestrutura e segurança. Com isso, o estudo reforça o papel que as ONGs tem em fortalecer as políticas executadas pelo Estado.

Dagnino (2004) critica esta relação entre a sociedade civil e o Estado, caracterizando este vínculo como o dilema da confluência perversa. Trata-se de um dilema, pois a autora destaca dois projetos vigentes que necessitam de uma sociedade civil atuante, há o processo de construção democrática em ambos os projetos. De um lado encontra-se o projeto neoliberal com o encolhimento das responsabilidades sociais do Estado e sua transferência para a sociedade civil. De outro lado, há um projeto democratizante, participativo, que emergiu da ditadura militar e dos diferentes esforços nacionais de aprofundamento democrático (Constituição de 1988), com a criação de espaços públicos: conselhos gestores, orçamento participativo. A autora questiona essa larga presença das ONGs como o avanço deste modelo neoliberal, chamando a atenção para um maior aprofundamento dos papeis que desempenham as diferentes organizações, para que se possa diferenciar os projetos políticos que 
respondam aos direitos universais ou que respondam às ações de indivíduos que desejam ser solidários com os mais pobres, numa perspectiva de caridade.

O questionamento reside na redefinição da noção de sociedade civil que sofreu uma aproximação perigosa do termo ONG. Segundo a autora, cada vez mais, as ONGs abandonam seu vínculo com os movimentos sociais, pois tem as agências internacionais e o Estado como financiadores, se tornaram prestadoras de serviços e não mais representam a sociedade civil.

Em grande parte dos espaços abertos à participação de setores da sociedade civil na discussão e na formulação das políticas públicas com respeito a essas questões, estes se defrontam com situações nas quais o que se espera deles é muito mais assumir funções e responsabilidades restritas à implementação e a execução de políticas públicas, provendo serviços antes considerados como deveres do Estado, do que compartilhar o poder de decisão quanto à formulação dessas políticas (DAGNINO, 2004, p. 152).

Esta parceria do Estado com a sociedade civil organizada é uma das fontes de financiamento das ONGs. Muitas delas, dependem em grande parte de recursos públicos. Uma outra forma de captação de recursos, denominada por Mendonça et al (2013) como Novos Formatos de Mobilização de Recursos, referem-se às doações de indivíduos, criação de fundos comunitários, ferramentas que se utilizam da web, das redes sociais e o telemarketing. Há ainda o Investimento Social Privado (ISP) caracterizado como o investimento que é feito por grandes empresas. São cerca de $94 \%$ das organizações privadas com mais de 500 funcionários responsáveis pela doação de recursos para questões sociais (MENDONÇA et al, 2013).

Com o fortalecimento da democracia e da justiça social foi possível a abertura para mais uma forma de financiamento das organizações da sociedade civil, a cooperação internacional, foco deste estudo. A cooperação internacional cresce a cada dia, inclusive para além da figura do Estado-Nação, tendo em vista a importância de organizações não governamentais. A cooperação internacional pode ter por objeto algum bem jurídico ou atividade ligada aos mais diversos ramos jurídicos: penal, administrativo, processual, trabalhista, tributário, previdenciário, dentre tantos outros (VALE, 2014).

A cooperação internacional atua na luta pelos direitos sociais principalmente no cenário de países em desenvolvimento. Buscando gerar mais desenvolvimento de maneira justa, através do envio de recursos financeiros para projetos e programas sociais. Essas instituições podem ser organizações públicas ou privadas.

É importante ressaltar que essas relações entre Estado ou organizações internacionais são de fato complexas em diferentes níveis, mas é fundamental estabelecermos que as ONGs ou OSCs não 
substituem o trabalho realizado pelo Estado, tampouco acredita-se que tenham essa intenção, pois o que muitas vezes ocorre é que ao prestarem serviços públicos e atividades assistencialistas, essas organizações também fazem o papel de cobrar políticas públicas para uma melhor atuação desses projetos, geralmente em âmbito nacional, podendo também ampliar projetos já implementados. Segundo França Filho (2002) ao referenciar Laville, o autor traz uma questão importante, a ligação do terceiro setor com o Estado, dizendo por sua vez, que essa relação de trabalho e contribuição pode fazer com que novas iniciativas e ações públicas sejam geradas. O autor cita como exemplo as sociedades de socorro mútuo na Europa, que trouxeram a ideia da previdência estatal, passando a ser utilizada pelo Estado.

Acredita-se que as relações de parceria entre o Estado e/ou com organizações internacionais são importantes e necessárias, pois a comunidade absorverá muito mais benefícios desta forma, sobretudo se a parceria for justa entre essas organizações e o Estado, e analisando-se sempre criticamente esta relação.

No caso do município de Barreira (CE), políticas públicas voltadas para o semiárido e sua convivência são fundamentais, a evolução dessas políticas e tecnologias trazem muitos benefícios e pontos positivos na convivência com o semiárido e com os problemas relacionados a seca e a falta de água no geral.

Assim, é fundamental ressaltar que o Programa de Cisternas não tem financiamento público, está pautado na cooperação internacional, que atualmente pode ser a melhor alternativa para essas políticas e programas sociais, uma vez que o cenário político atual é preocupante, devido aos governos se ausentarem de suas atribuições.

\section{Metodologia}

Foi utilizado o método de pesquisa exploratória, que tem como objetivo "proporcionar maior familiaridade com o problema, com vistas a torná-lo mais explícito ou a constituir hipóteses” (GIL, 2002, p.41). O estudo baseou-se no Programa de Cisternas desenvolvido pela Associação Internacional em cooperação com a Organização Nacional, quanto à melhora nas vidas das famílias beneficiadas. Para isso a abordagem de pesquisa é classificada como qualitativa, "se preocupa com aspectos da realidade que não podem ser quantificados, centrando-se na compreensão e explicação da dinâmica das relações sociais." (FONSECA, 2002, p.20), uma vez que serão tratados aqui de aspectos subjetivos, que não podem ser expressos numericamente. 
A pesquisa utilizou-se da revisão bibliográfica e documental, com o foco nos temas de "terceiro setor", "organizações não governamentais" e "cooperação internacional”. A pesquisa bibliográfica utiliza-se de registros já disponíveis resultantes de pesquisas anteriores, como livros e artigos. A pesquisa documental se relaciona a coletas de dados, tais como jornais, fotos, filmes, gravações e documentos legais (SEVERINO, 2007, p.122-123) feitas no âmbito da Organização Nacional que foi realizado antes da ida a campo com a finalidade de conhecer e selecionar as famílias.

A análise dos dados foi feita considerando-se o que Cohen e Franco (1993) sugerem para uma análise de projetos sociais quanto à eficiência em sua utilização e a comprovação de sua eficácia para alcançar seus objetivos. Assim, nesta análise, os critérios básicos utilizados são a eficiência e a equidade, que estão relacionadas à satisfação das necessidades básicas dos indivíduos. "A política social cumpre o objetivo de investir em recursos humanos (que pode ser interpretado como "ensinar a pescar") mas necessita que o sistema esteja em condições de demandar esse pessoal" (COHEN \& FRANCO, 1993, p.22).

A Organização Nacional se dispôs a fornecer os dados necessários possíveis para a pesquisa e uma funcionária ficou encarregada de ajudar com as fichas dos beneficiários e a localizá-los no município, visto o seu conhecimento de campo. Esta organização, segundo o que está descrito em seu site (ORGANIZAÇÃO, 2019), foi fundada em 2001 no município de Barreira (CE) a partir das necessidades de promover ações e criar projetos que auxiliassem na promoção do direito a água. Tais ações se circunscreveram ao município de Barreira, mais especificamente àqueles distritos localizados a muitos quilômetros de distância do centro da cidade e seriam equivalentes às políticas públicas de nível municipal (SILVEIRA \& SOUZA, 2016).

Para a pesquisa de campo, durante as visitas feitas a Organização Nacional, as fichas dos beneficiários foram analisadas e com isso foram selecionadas cinco famílias beneficiadas entre os anos de dois mil e dezessete (2017) e dois mil e dezenove (2019) nas comunidades de Jatobá II e Olaria II.

Ambas as comunidades de Jatobá II e Olaria II estão localizadas nas margens periféricas do centro do município de Barreira (CE), situadas em pontos diferentes da cidade, no início da zona rural do município. Socioeconomicamente parecidas, em sua maioria são famílias de baixa renda, geralmente composta por agricultores e agricultoras rurais e pequenos produtores de castanha de caju.

O uso de entrevistas foi utilizado como técnica de pesquisa, a partir de visitas às casas, com um roteiro de doze perguntas semiestruturadas. As entrevistas foram feitas de modo presencial nos dias 17 e 20 de dezembro de 2019. Foram realizadas cinco entrevistas, onde uma pessoa por família 
respondeu perguntas referentes ao programa. Cada entrevista foi feita na casa do respectivo entrevistado, assim os indivíduos poderiam ficar mais à vontade para conversar. Todos os entrevistados assinaram uma autorização onde permitiram o uso dos dados para o presente artigo.

Com relação à Associação Internacional, foi estabelecido contato com o coordenador da instituição, uma vez que esta é a criadora e financiadora do programa. Foi utilizado uma espécie de questionário com 10 perguntas relacionadas a instituição e seu trabalho, este foi encaminhado por $e$ mail e o coordenador do programa respondeu às perguntas. A Associação Internacional também foi bastante prestativa às indagações, levando-se em consideração que sua sede é na Itália.

A Associação Internacional, segundo seu site oficial, é uma entidade sem fins lucrativos fundada em 1998, em Bérgamo, Itália. A associação foi criada por um grupo de amigos cuja primeira iniciativa foi a de ajudar um centro de apoio para crianças portadoras de HIV/AIDS em Salvador (BA). A entidade também ajudou outras associações que trabalham no campo da saúde, educação e construção civil e em outras áreas do mundo como o México, Nicarágua, Turquia, Moçambique, Bósnia e Afeganistão. Atualmente, a associação realiza projetos em todo o estado do Ceará e na Itália.

Com isso, o presente trabalho está pautado em informações obtidas e utilizadas de maneira responsável, levando-se em consideração o respeito à privacidade de todos os indivíduos envolvidos.

\section{O Programa de Cisternas em Barreira (CE)}

O município de Barreira (CE) localiza-se na região do Maciço de Baturité, distante cerca de 72 quilômetros da capital Fortaleza. Sua população estimada em 2018 foi de 21.104 habitantes (IPECE, 2018).

O programa de cisternas foi iniciado no ano de 1999, quando o representante da Associação Internacional junto ao fundador da Organização Nacional conheceram o Pároco da Igreja Matriz de Barreira no Fórum de Semiárido em Fortaleza (CE). Este pediu ajuda às organizações sobre a falta de água na cidade, mas foi um Padre italiano da Pastoral da Terra que deu a ideia das cisternas.

Com isso foi criado o Programa de Cisternas, visando melhorar a qualidade de vida das famílias que

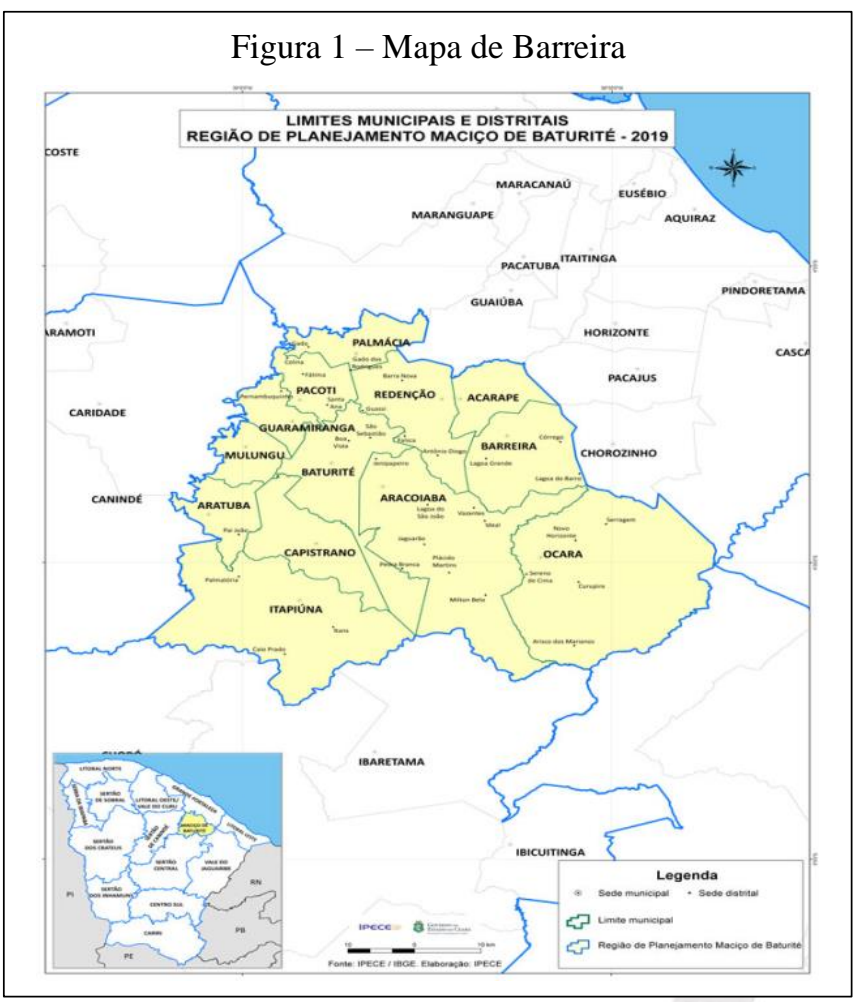


vivem nas áreas mais afastadas do acesso a água no semiárido cearense por meio da construção de cisternas de concreto para o armazenamento de água.

Cabe destacar que o programa de cisternas desenvolvido pela Associação Internacional não é o mesmo programa de cisternas do Governo Federal. Apesar de partirem da mesma problemática, que é a falta d'água, os programas diferem quanto à fonte de recursos financeiros e a utilização dessas águas captadas.

O programa de cisternas do Governo Federal (BRASIL, 2020) tem foco não apenas em famílias que são atingidas pela seca ou que lhes falte água frequentemente. A implementação ocorre também nas escolas e nas atividades produtivas, com capacidade de até 52 mil litros de água. As famílias devem estar registradas no Cadastro Único para Programas Sociais do Governo Federal, este atua principalmente na região semiárida brasileira. O financiador dos recursos é o próprio governo federal que necessita da parceria de organizações da sociedade civil para a construção dessas cisternas. Logo no início do programa, o material utilizado para a construção das cisternas era de plástico, o que gerou muita insatisfação por parte da ASA e de agricultores que relataram os problemas relacionados à durabilidade, deformação e custo. Então, a partir de 2014 passaram a utilizar as cisternas de placa (COSTA, 2014).

O programa de cisternas da Associação Internacional é financiado pela própria entidade por meio da captação de recursos que realiza. Para obter o benefício, as famílias precisam estar afastadas de fontes de acesso à água, sendo o uso basicamente doméstico. Assim como o governo federal, esta associação depende de outra organização da sociedade civil para construir a cisterna, neste caso, a Organização Nacional.

\section{Resultados e Discussões}

Os dados obtidos mostram que até o dia 31 de dezembro de 2019, foram construídas 442 (quatrocentos e quarenta e duas) cisternas, sendo 2.617 pessoas beneficiadas. Conforme o que está disponibilizado no site da Associação Internacional (Internacional, 2020) e como foi disponibilizado pela Organização Nacional, o programa possui duas diretrizes: 1) Construção de cisternas de concreto para a captação de água da chuva: cada família recebe uma cisterna, com capacidade que varia de 10.000 até 16.000 litros. 
Figura 2 - Cisterna construída no quintal de uma das famílias entrevistadas

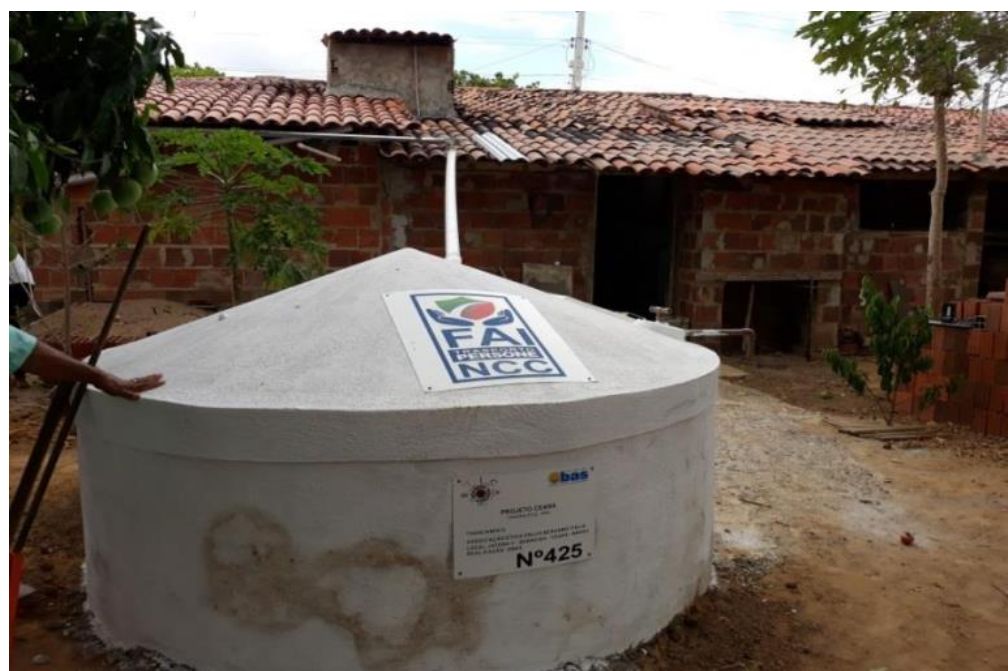

Fonte: autoras (2019)

A seleção desta família é feita com base em três critérios, sendo eles: a) família mais numerosa; b) família que vive mais longe das fontes de água (rios, lagos, represas e poços públicos); e, c) menores de idade devem estar na escola. A outra diretriz: 2) Formação profissional para jovens agricultores especializados em técnicas de convivência com o semiárido nordestino.

Para receber a cisterna de 16.000 litros, a família deve ser composta por no mínimo cinco pessoas. Para a de 10.000 litros, deve ser composta por no mínimo quatro pessoas. Em ambas as famílias devem-se ter filhos. As famílias selecionadas comprometem-se a participar de um curso de manutenção da cisterna, disponibilizado pela Organização Nacional, além de ajudar no trabalho de escavação para construção da cisterna (Organização, 2019).

Uma das dificuldades para manter os projetos sociais reside na captação de recursos. As organizações financiadoras desempenham este papel de suprir cenários de dificuldades, como relatado pela Associação Internacional. A forma como se mantém depende da doação de pessoas físicas e pessoas jurídicas que se interessam pelo projeto de construção de cisternas. Seu representante relembrou a chegada da organização no Brasil, nos anos 1990, no governo de Fernando Henrique Cardoso, quando encontraram um cenário de escassez em relação às ações voltadas às populações mais necessitadas e que atualmente vê um retrocesso no país com relação à utilização de seus recursos.

Na visita de campo, pôde-se perceber primeiramente, que as casas, das famílias beneficiadas, estão localizadas a uma distância considerável do centro do município. As famílias entrevistadas estavam em duas localidades do município de Barreira, Jatobá II e Olaria II, onde o acesso à água é 
mais difícil quando comparado ao acesso na área urbana e central do município. Outra observação é que as casas visitadas aparentam ser mais simples, de alvenaria e com construções mais antigas.

Com relação às entrevistas, foi clara a importância e os benefícios trazidos pelo programa, pois todos os entrevistados se mostraram felizes e agradecidos por terem sido beneficiados. Tudo isso resulta em uma aproximação maior dessas entidades com as comunidades e os beneficiários, conforme foi observado na pesquisa do IPEA de Lopez e Abreu (2014).

Quando perguntados sobre como e onde buscavam água antes da instalação das cisternas, os entrevistados lembraram-se de como era difícil, pois tinham que obtê-la em algum lugar geralmente distante de casa ou comprar carro pipa. Os entrevistados relataram ser muito cansativa essa busca por água. Com a cisterna, a preocupação com este fator diminuiu consideravelmente, tornando a vida mais confortável. "Era horrível, a gente tinha que ir buscar lá no chafariz, lá longe, a gente ia buscar de tambor em tambor. Todo dia tinha que ir buscar...” (ENTREVISTADO 1). "Às vezes quando faltava, eu contratava carroça pra vir deixar um tambor de água, porque falta muita água em Barreira...agora, se passar um mês sem água da CAGECE - Companhia de Água e Esgoto do Ceará, dá para aguentar" (ENTREVISTADO 2).

Outros benefícios trazidos pela cisterna são destacados a partir de algumas afirmações feitas pelos beneficiados, a saber: a) A economia financeira com água: tanto no que diz respeito à conta de água encanada, que passa a ser menos utilizada, como à compra de água para beber e para ser utilizada nos serviços da casa; b) a inexistência de preocupação com a falta de água encanada e consequentemente a diminuição do trabalho para buscar em poços e cacimbas ${ }^{5}$ distantes.

Sobre a utilização da água, das cinco famílias entrevistadas, duas afirmaram utilizar a água, quando captada da chuva, somente para beber. Já as demais além de utilizar para beber, utilizam nos serviços da casa, para cozinhar, lavar roupas, tomar banho, lavar louças, além de cuidar das pequenas plantações que alguns possuem em seus quintais. Assim, segundo os entrevistados, o programa impacta de maneira positiva em suas vidas cotidianas, uma vez que cumpriu o seu papel, que é o de facilitar a vida com relação à água nessas famílias.

Sobre o armazenamento da água, as famílias participaram de cursos e palestras na sede da Organização Nacional, onde aprenderam a cuidar da cisterna e a mantê-la em funcionamento. Todos aparentaram entender bastante sobre aspectos relacionados a como tratar a cisterna, pois em algum

\footnotetext{
${ }^{5}$ Cacimbas ou olhos d'água são escavações rasas feitas em riachos temporários para se aproveitar as águas subterrâneas, resultantes da infiltração da água das chuvas no solo. (PORTO et all, 2004)
} 
momento já possuíram algum tipo de "cacimba" em casa, visto que isso parece ser um costume comum dos mais antigos que vivem no Ceará.

Um aspecto importante que foi possível perceber nas entrevistas, foi com relação a quantidade de água armazenada. A cisterna de 16.000 litros é disponibilizada somente às famílias que possuem no mínimo cinco pessoas na casa e a de 10.000 litros no mínimo quatro pessoas, mas todas as famílias relataram fazer uso conjunto da cisterna com a água encanada, quando não está em falta; ou seja, nenhuma das famílias utiliza apenas a água da cisterna. Este resultado mostra a necessidade de um maior aprofundamento desses relatos, pois em outro estudo com outras comunidades, a água armazenada não é suficiente (COSTA, 2014).

Outra questão analisada, é sobre as mulheres e sua maior preocupação em falar sobre o que mudou em suas vidas cotidianas. Das cinco famílias entrevistadas, quatro tinham representantes mulheres e todas buscaram junto à Organização Nacional, o benefício da cisterna, visto a grande necessidade que tinham e as grandes dificuldades acerca da água. Ressalta-se que estas mulheres buscavam há anos solucionar esta questão. O que foi notadamente percebido, é que as mulheres, por terem mais trabalho e por fazerem mais serviços em casa, de certa forma valorizam os benefícios que tal programa trouxe.

Pontes (2013) retrata o papel da mulher sertaneja e da sua relação com a água. Ela tem um papel muito importante nessa relação, uma vez que além de cuidar dos serviços da casa, cuida das atividades agrícolas e em sua maioria é ela que cuida do abastecimento de água. Apesar da subestimação da mulher, esta assume o papel de chefe de família quando os homens precisam se ausentar. O autor utiliza o caso do projeto "Um Milhão de Cisternas Rurais (P1MC)", que tem como um de seus critérios, casas de famílias beneficiadas com mulheres como chefes de família, o que traz uma forma de valorização do papel da mulher.

O papel das mulheres no semiárido é um retrato de como são fortes e poderosas, mesmo nem todas tendo consciência disso. São elas que sustentam a unidade familiar, jovens ou idosas, trabalhadoras domésticas ou intensamente no campo e continuam resistindo e lutando pela sobrevivência, encontrando formas dentro da lógica da convivência. Por isso, o fim das longas caminhadas, com peso das latas d'água na cabeça, propiciado pelas cisternas, é um começo para uma boa convivência no semiárido (PONTES, 2013, p. 19).

Com isso, é importante ressaltar o papel da mulher, além de estimular o desenvolvimento de ações e políticas que incluam as questões de gênero e das mulheres que vivem no semiárido e nas áreas rurais. 
Os entrevistados também mostraram sua indignação por parte do sistema hídrico do município, onde relataram a falta de água por até dois meses seguidos. Isso mostra que no município de Barreira (CE), os problemas de falta de água vão muito além do clima e da região em que estão inseridos. Há problemas estruturais e governamentais, tais como encanamento antigo, o que impede que a água chegue às casas por uma semana inteira sem interrupções. Além do desinteresse da gestão local em lidar com essa questão. "Estava faltando água? Chegou, só deu pra abastecer a cisterna... se não fosse a cisterna..." (ENTREVISTADO 4)

Outra situação também destacada por Dagnino (2004) é com relação ao papel das organizações da sociedade civil em se tornarem apenas prestadoras de serviços públicos, e deixar de lado o seu papel de representantes da sociedade em relação a suas reais necessidades. No presente estudo, nota-se um esforço em permitir a convivência com o semiárido e a luta pelo direito a água. Para o futuro, há que se ter o cuidado de não transformar suas ações em um programa de caridade. A publicidade dada às ações realizadas pelo programa poderá trazer visibilidade e novos projetos sociais e a criação de políticas públicas.

\section{Considerações Finais}

$\mathrm{Na}$ reta final deste estudo, considera-se que foram apresentados os aspectos relativos ao tema proposto. A pesquisa pôde levantar questões e reflexões que ficaram em aberto, mas que podem e devem ser preenchidas posteriormente. Com isso, os objetivos aqui propostos, assim como a questão principal que o norteou, sobre os benefícios que o Programa de Cisternas trouxe, foram alcançados. O acesso à água é uma realidade nas atividades domésticas das famílias consideradas.

O Programa de Cisternas nasce da necessidade da população de Barreira (CE) em armazenar água, visto os problemas acerca do abastecimento já conhecidos no município. O programa visa atender as populações rurais e mais afastadas do centro, que se viam excluídas desse acesso. Os dados mostram que o Programa de Cisternas foi bem recebido pelos seus beneficiários, todos se mostraram satisfeitos e os resultados foram positivos em suas vidas, pois agora contam com a facilidade e garantia no acesso à água.

Ainda se destaca como lacuna do programa, a falta de propostas acerca do principal problema que se tem no município sobre o acesso à água, onde o abastecimento é falho devido às razões que não ficaram explícitas no estudo. Há deteriorações no encanamento, há períodos de estiagem na região, ou seja, esses questionamentos poderiam ser utilizados de forma a atingir a raiz do problema, 
a partir de uma discussão e de um levantamento com a própria comunidade sobre esses fatos. Com uma sociedade civil propositiva e um projeto bem planejado seria possível apresentar um modelo mais efetivo de combate à falta de água.

As organizações do terceiro setor, por sua vez, enfrentam grandes dificuldades em sua trajetória, reconhecimento, sustentabilidade financeira e concorrência para se consolidarem no país. Sua luta para a defesa dos direitos sociais da população, esbarra na principal dificuldade para a sua existência, que é a captação de recursos.

As parcerias com o Estado, as cooperações internacionais e tantas novas formas de captação de recursos são de grande importância para o crescimento, consolidação e manutenção de projetos e políticas sociais no Brasil.

No entanto, a questão que fica nesta pesquisa é acerca da permanência do programa e da preocupação em relação a sua continuidade. Os problemas referentes ao abastecimento de água no município parecem não cessar, com isso, o programa apenas reforça a sua importância. Reforça igualmente a necessidade de compreender o papel das ONGs no processo de desenvolvimento local pois neste caso as entidades envolvidas mostraram-se muito responsáveis na maneira como tratam a vida e as necessidades dessas famílias, são visíveis os impactos deixados. Ressalta-se o descaso por parte de autoridades governamentais locais o fato de o município ser conhecido pela população e por seus gestores, por seus problemas acerca do abastecimento de água, e possuir apenas um programa que busque tratar dessas questões.

Portanto, fica evidente a necessidade de investimentos e de novas políticas que de alguma forma venham a suprir as necessidades da população residente em Barreira (CE) que sofre diariamente com os problemas de acesso a água.

Enfim, pode-se verificar que o acesso à água traz questões muito mais profundas acerca de questões sociais e de vulnerabilidade que atinge toda a população, em diferentes níveis. Discutir a água se mostrou muito mais complexo, levantando-se questões relacionadas à aspectos financeiros (origem dos recursos e gestão do projeto), de gênero, políticos, de desenvolvimento local (atuação das ONGs e governo), de participação social e de saúde dada a pandemia de Covid-19 e sua influência no agravamento de toda essa situação, que poderiam ser temas para estudos futuros.

\section{Referências}

ABONG - Associação Brasileira de Organizações Não Governamentais. Estatuto Social. Abong. São Paulo, 16 de março de 2016. 
ASA - Articulação do Semi-árido Brasil. Disponível em: http://www.asabrasil.org.br. Acesso em 15 jul 2019.

BRASIL. Lei ${ }^{\circ}$ 10.406, de 10 de janeiro de 2002. Institui o Código Civil. Diário Oficial da União: seção 1, Brasília, DF, ano 139, n. 8, p. 1-74, 11 jan. 2002. Disponível em: http://www.planalto.gov.br/ccivil_03/leis/2002/110406.htm. Acesso em: 04 nov 2019.

BRASIL. Lei no 13.019, de 31 de julho de 2014. Disponível em: http://www.planalto.gov.br/ccivil_03/_ato2011-2014/2014/lei/113019.htm. Acesso em: 04 nov 2019.

BRASIL. Ministério da Cidadania. Secretaria Especial do Desenvolvimento Social. Programa Cisternas. Brasília, DF, [s.d]. Disponível em: http://mds.gov.br/assuntos/seguranca-alimentar/acessoa-agua-1/programa-cisternas. Acesso em: 21 jan 2020.

COHEN, E; FRANCO, R. Avaliação de projetos sociais. Petrópolis, RJ: Vozes, 1993.

COSTA, C.V. Análise da gestão das águas nas cisternas de placas das comunidades: Santa Vitória e Patos no Município de Granjeiro - CE. Dissertação (mestrado profissional) - Universidade Federal do Ceará, Mestrado Profissional em Gestão de Recursos Hídricos, Fortaleza, 2014.

DAGNINO, E. Construção democrática, neoliberalismo e participação: os dilemas da confluência perversa. Política \& Sociedade, v. 3, n. 5, p. 139-164, 2004.

DE ALBUQUERQUE, A.C.C. Terceiro setor: história e gestão de organizações. Summus Editorial, 2006.

Associação Internacional. Página Inicial. [s.d]. Disponível em: https://www.internacionalbrasile.it/home-3/. Acesso em: 06 jun 2019.

FERNANDES, R.C. Privado porém público: o terceiro setor na América Latina. Rio de Janeiro: Relume-Dumará, 1994.

FONSECA, J. J. S. Metodologia da pesquisa científica. Fortaleza: UEC, 2002. Apostila.

FRANÇA FILHO, G. C. de. Terceiro setor, economia social, economia solidária e economia popular: traçando fronteiras conceituais. Bahia Análise \& Dados, v.12, n. 1, p. 9-19, 2002.

FUCHS, R. M. Manual do terceiro setor. Jardim Paulista: Instituto Pro Bono, 2013.

GIL, A. C. Como elaborar projetos de pesquisa. São Paulo, v. 5, n. 61, 2002.

IBGE, Instituto Brasileiro de Geografia e Estatística. As fundações privadas e associações sem fins lucrativos no Brasil: 2016. Rio de Janeiro: IBGE, 2019.

IPECE, Instituto de Pesquisa e Estratégia Econômica do Ceará. Mapa municipal de Barreira. Ceará: IPECE, 2018. Disponível em <http://ipecedata.ipece.ce.gov.br/ipece-dataweb/module/anuario.xhtml>. Acesso em: 21 jan 2020. 
LOPEZ, F. G.; ABREU, R. A participação das ONGs nas políticas públicas: o ponto de vista de gestores federais. Texto para discussão, Instituto de Pesquisa Econômica Aplicada (IPEA), 2014.

MENDONÇA, P. M. E. et al. Pesquisa arquitetura institucional de apoio às organizações da sociedade civil no brasil. Apresentação e Resumo Executivo. Articulação D3 - Diálogos, Direitos e Democracia CEAPG - EAESP - FGV, 2013.

Organização Nacional. Página Inicial. [s.d]. Disponível em: http://organizaçãonacional.org.br/. Acesso em: 06 jun 2019.

OLIVEIRA, A. C.; HADDAD, S. As organizações da sociedade civil e as ONGs de educação. Cadernos de Pesquisa, n. 112, p. 61-83, 2001.

OLIVEIRA, E. A.; GODÓI-DE-SOUSA, E. O Terceiro Setor no Brasil: avanços, retrocessos e desafios para as Organizações Sociais. Revista Interdisciplinar de Gestão Social, v.4, n.3, 2015.

PONTES, E. T. A estreita relação entre mulher e água no semiárido: o caso do programa um milhão de Cisternas rurais. Revista Latino-americana de Geografia e Gênero, v. 4, n. 1, p. 14-21, 2013.

PORTO, E.R.; BRITO, L.T.L.; ANJOS, J.B.; SILVA, M.S.L. ABC da Agricultura Familiar. Formas de garantir água nas secas 2. Barragens, cacimbas e poços amazonas. Embrapa Semi-Árido, 2004.

SEVERINO, A. J. Metodologia do trabalho científico. Cortez editora, rev. São Paulo, 2007.

SILVEIRA A. K. T. ; SOUZA, G. H. O. Organização Barreira Amigos Solidários - Obas como meio de desenvolvimento regional. In: Anais da Semana de Iniciação Científica, Faculdade do Maciço de Baturité, 2016.

VALE, H. E. G. Princípio da cooperação internacional. Revista Jus Navigandi, Teresina, ano 19, n. 3864, 29 jan. 2014. Disponível em: https://jus.com.br/artigos/26542. Acesso em: 06 jan. 2020. 


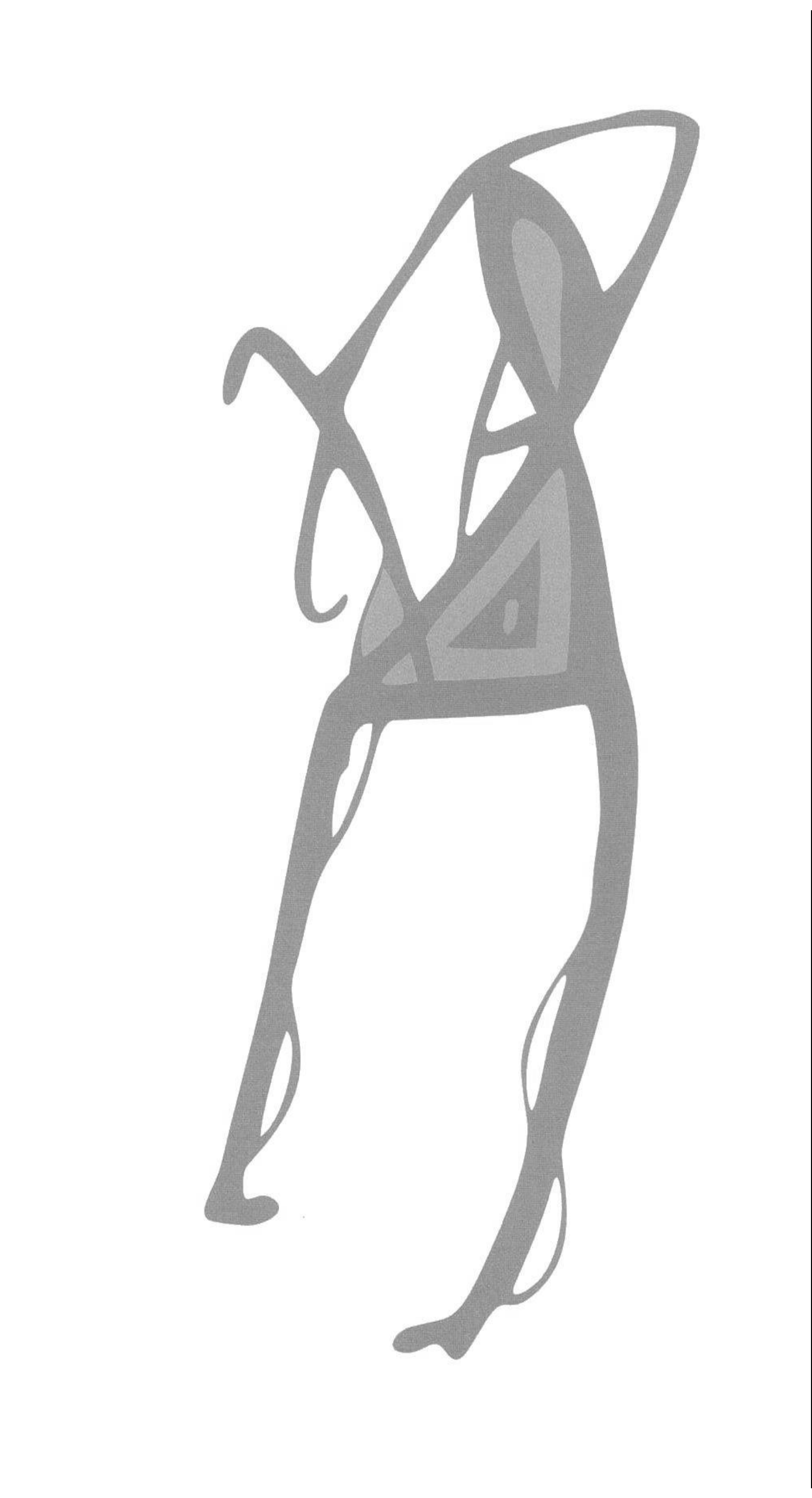


ARAUJO, Francisco Antonio Machado; FERRO, Maria da Glória Duarte. Docência e pesquisa em formação de professores: primeiras aproximações ao objeto de estudo. Teresina: EDUFPI, 2018.

Resumo: trata-se de resenha da obra "Docência e pesquisa em formação de professores: primeiras aproximações ao objeto de estudo", organizada pelos professores Francisco Antonio Machado Araujo e Maria da Glória Duarte Ferro e publicada em 2018, pela EDUFPI.

Palavras-chave: Formação de professores. Docência. Pesquisa. Resenha.
Abstract: it is a review of the work "Teaching and research in teacher training: first approaches to the object of study", organized by professors Francisco Antonio Machado Araujo and Maria da Glória Duarte Ferro and published in 2018, by EDUFPI.

Keywords: Teacher training. Teaching. Search. Review.

\footnotetext{
${ }^{1}$ Doutor em Educação (PUCRS). Licenciado e Mestre em Geografia (UFRGS). Professor do Departamento de Humanidades da Universidade Federal do Rio Grande do Sul (UFRGS). E-mail: victor.juventudes@gmail.com
} 
O livro "Docência e pesquisa em formação de professores: primeiras aproximações ao objeto de estudo" foi escrito a muitas mãos e organizado pelos professores Francisco Antonio Machado Araujo e Maria da Glória Duarte Ferro. A obra foi publicada em 2018, pela EDUFPI, editora vinculada à Universidade Federal do Piauí e teve como principal objetivo refletir sobre a produção de conhecimentos que possam transformar-se em embasamentos para a formação de estudantes da graduação, investigadores e professores em todos os níveis de ensino. A obra é dividida em oito capítulos, para além da apresentação, do prefácio e do prólogo que abrem a publicação. A tarefa de produzir conhecimentos sobre os aspectos da docência e da pesquisa no campo da formação de professores é entendida como empreitada de profunda necessidade na contemporaneidade, haja vista a constante necessidade de repensar as técnicas e métodos das didáticas e das reflexões sobre a práxis docente.

Nesse sentido, o primeiro capítulo, de autoria de Maria da Glória Duarte Ferro e Neide Cavalcante Guedes, em uma linha introdutória, busca promover reflexão a partir da articulação entre formação e prática docente, pensando esse tema, em especial, a partir das interlocuções do Plano Nacional de Formação de Professores da Educação Básica, o PARFOR, e tendo como cenário a Universidade Federal do Piauí e, em especial, o curso de pedagogia. As autoras do capítulo apropriam-se de denso referencial teórico do campo da formação de professores, para ancorarem seus argumentos em particular em três fases do processo de ensinar e aprender, as quais consideram essenciais para que se atinja uma plena formação de professores: formação inicial, período de iniciação e desenvolvimento profissional. Apregoam a necessidade da adoção de medidas em caráter de urgência, para que se evite o comprometimento da qualidade da política de formação de professores, entre essas medidas, destacam-se os temas da normatização, do diálogo, da sondagem e do fomento.

O capítulo dois, de autoria de Lúcia Maria de Sousa Leal Nunes e Maria da Glória Soares Barbosa Lima, evoca a demanda de se pensar a formação docente em terrenos fora da universidade, no sentido de promover reflexão sobre as exigências contemporâneas na formação de professores. O tema do cotidiano docente emerge na análise proposta pelo capítulo, uma vez que são provocadas reflexões críticas sobre a prática pedagógica no dia a dia dos professores. Fica evidenciado, no texto, de que os espaços pedagógicos servem de espaço-tempo de aprendizagem tanto para estudantes, quanto para seus professores. Já o terceiro capítulo, de Francisco Antonio Machado Araujo e Maria Vilani Cosme de Carvalho, traz à baila a temática da Pós-Graduação stricto sensu no campo da educação e como essa etapa de ensino e pesquisa apresenta potencial emergente para o pleno 
desenvolvimento dos professores do ensino superior. Há um importante alerta para a constituição eminente voltada à pesquisa o que, segundo os autores, pode constituir-se, de alguma forma, em dificuldades para o desenvolvimento profissional docente do professor do ensino superior.

O quarto capítulo, elaborado por Francisca Maria da Cunha de Sousa e Neide Cavalcante Guedes, coloca em tela algumas discussões sobre o Pacto Nacional Pela Alfabetização na Idade Certa, o PNAIC, a partir de debates que envolvem a formação de professores alfabetizadores no âmbito do programa. São tensionadas as questões que envolvem o caráter dicotômico entre teoria e prática e é evidenciado o fato de que a formação continuada possui um importante desafio: promover a reflexão crítica sobre a prática docente, para profissionais já iniciados do campo da prática. Esse processo, segundo as autoras, coloca o profissional como sujeito de sua prática e provoca momentos e espaços amplamente formativos. É apontado que as práticas docentes necessitam serem orientadas a partir de múltiplos saberes, dentre esses, os saberes construídos no âmbito da formação continuada, que esteja atenta aos desafios propostos pela contemporaneidade, como é o caso da proposta apresentada pelo PNAIC.

O quinto capítulo, de autoria de José Ferreira da Silva Junior e Luís Carlos Sales, por sua vez, propõe análise, a partir de levantamento bibliográfico e documental, sobre o tema da prática docente no âmbito da educação infantil, a partir do Sistema de Avaliação Educacional de Teresina, o SAETHE, sistema esse que é entendido como uma política pública de avaliação externa em larga escala, a qual possibilita investigar e acompanhar a educação pública municipal de Teresina, a partir de instrumentos específicos e, com isso, apresentar evidências para repensar a atuação e gestão pedagógica. Os autores ressaltam a importância da prática docente na educação infantil e apontam que tal prática é influenciada por múltilplos fatores, internos ou externos à escola e à educação. $\mathrm{O}$ sexto capítulo, escrito por Vilma da Silva Mesquita Oliveira e Maria do Amparo Borges Ferro, apresenta importante debate que envolve a perspectiva do movimento da Nova História Cultural, que foi pensado a partir de uma nova perspectiva de análise da realidade, a qual inseriu a criança, como sujeito de direitos, no centro dos processos educativos, e, a partir da natureza própria das infâncias, pensar na utilização das atividades lúdicas como processos de ensino e aprendizagem. Nesse sentido, também foi pensada a formação docente, na qual os saberes docentes não se constituem de algo meramente técnico, mas que possam promover uma formação mais ampla.

O sétimo capítulo, de autoria de Maria Dolores dos Santos Vieira e Shara Jane Holanda Costa Adad, dispôs-se a debater a questões do gênero e da formação inicial de jovens mulheres estudantes do curso de pedagogia da Universidade Federal do Piauí. Apresentam e discutem uma interessante 
proposta: a produção de "confetos", entendida como as relações obtidas entre os conceitos e os afetos. Uma das principais bases epistêmicas da proposta investigativa é a sociopoética, criada pelo filósofo e pedagogo Jacques Gauthier, a partir de experiências por ele vividas. Há o entendimento de que o gênero ocupa importante papel na formação inicial das jovens estudantes de pedagogia no espaço analisado, compreendendo, inclusive, a construção de táticas de resistências e de micro e macropolíticas no âmbito interno da Universidade e na formação de professores como campo de atuação e pesquisa. O último capítulo, por fim, de autoria de Lourdes Angélica Pacheco Cermeño e Luis Carlos Sales, abarca a necessária discussão sobre educação inclusiva e a formação docente. São destacados os desafios que as universidades enfrentam em relação ao tema no contemporâneo, uma vez que se assume a heterogeneidade da universidade como meio facilitador da inclusão, que diz respeito à multiplicidade de sujeitos: negros, mulheres, LGBTQIA+, pobres, estrangeiros, entre outros.

Ao final da leitura da obra, percebe-se como a temática da formação docente perpassa variados campos dos saberes e, também, pode ser compreendida nos diversos âmbitos formativos, desde a educação infantil até a pós-graduação. O leitor depara-se com a necessidade de assumir um compromisso ético, estético e político: de promover, em seus espaços de atuação, a defesa pela necessidade de sempre pensar na questão da formação docente e suas múltiplas interseções. 
